DOE/RL-96-63

Revision 1

UC-630

\title{
Annual Hanford Site Environmental Permitting Status Report
}

Date Published

October 1997

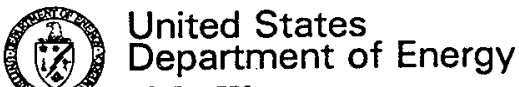

P.O. Box 550

Richland, Washington 99352 
TRADEMARK DISCLAMER

Reference herein to any specific commercial product, process,

or service by trade name, trademark, manufacturer, or otherwise, does not necessarily constitute or imply its endorsement, recommendation, or favoring by the United States Government or any agency thereof or its contractors or subcontractors.

This report has been reproduced from the best available copy. Aveilable in paper copy and microfiche.

Available to the U.S. Department of Energy and its contractors from

Office of Scientific and Technicel Information

P.O. Box 62

Oak Ridge, TN 37831

(615) $576-8401$

Available to the public from the U.S. Department of Commerce National Technical Information Service

5285 Port Royal Road

Springfield, VA 22161

(703) $487-4650$

Printed in the Unitad States of America

DISCLM-CHP (8-91) 


\section{RELEASE AUTHORIZATION}

Document

Number:
D0E/RL-96-63, Rev, 1

Document

Title:
Annual Hanford Site Environmental Permitting Report

This document, reviewed in accordance with DOE Order 1430.1D, "Scientific and Technical Information Management," and DOE G 1430.1D-1, "Guide to the Management of Scientific and Technical Information," does not contain classified or sensitive unclassified information and is:

\section{APPROVED FOR PUBLIC RELEASE}

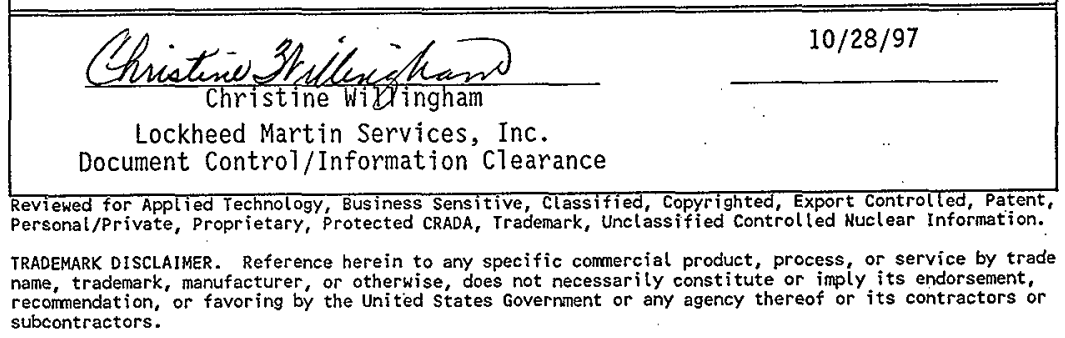


THIS PAGE INTENTIONALLY IEFT BLANK 


\section{INFORMATION RELEASE REQUEST \\ PUBLIC DOCUMENT CHANGE/REVISION \\ (Short Form No. 1)}

1. Base Document ID Number: DOE/RL-96-63, Rev. 1

2. Base Document Title:

Annual Hanford Site Environmental Permitting Report

3. Change/Revision Number: Revision 1

4. Change/Revision Date: '10/97

5. Unclassified Category: ${ }^{*}$ UC -630

6. Budget \& Reporting Code:* B\&R -

I verify this change/revision to the base document indicated above:

- Complies with the provisions of WHC-CM-3-4

- Contains no Limited-Use information

- Contains no classified or Applied Technology references

- Does not change the intent or meaning of the base document

- And, the base document itself is approved for public release.

7. Responsible Manager: R. H. Engelmann

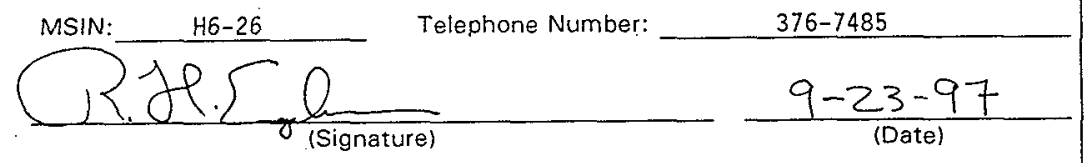

8. Information Release Administration Specialist: *

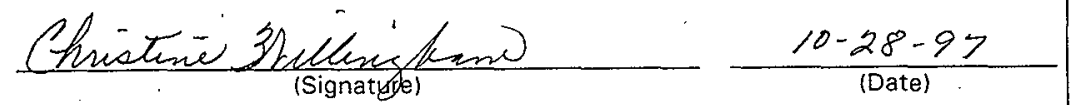

* Required only for full revisions transmitted to OSTI.

* * Required only for full revisions. 
THIS PAGE INTENTIONALLY LEFT BLANK

DOE/RL-96-63, Rev. 1 


\section{ANNUAL HANFORD SITE \\ ENVIRONMENTAL PERMITTING STATUS REPORT}

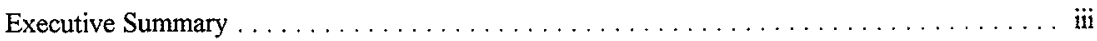

\section{RESOURCE CONSERVATION AND RECOVERY ACT PERMITTING}

\section{PART A AND PART B PERMITTING}

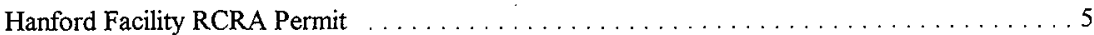

200 Area Effluent Treatment Facility . . . . . . . . . . . . . . . . . . . . . 6

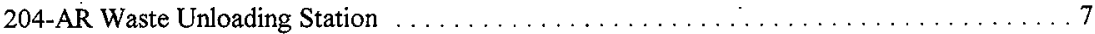

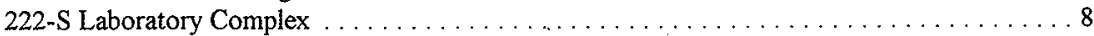

224-T Transuranic Waste Storage and Assay Facility . . . . . . . . . . . . . . . . 9

$241-Z$ Treatment and Storage Tanks . . . . . . . . . . . . . . . . . . . . . 10

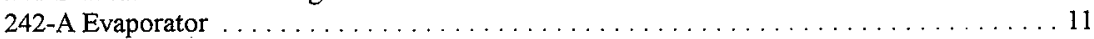

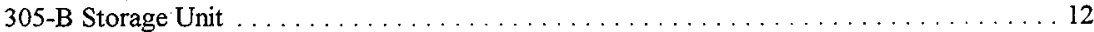

325 Hazardous Waste Treatment Units . . . . . . . . . . . . . . . . . . . 13

600 Area Purgewater Storage and Treatment Facility . . . . . . . . . . . . . 14

616 Nonradioactive Dangerous Waste Storage Facility $\ldots \ldots \ldots \ldots \ldots \ldots \ldots \ldots \ldots \ldots \ldots \ldots$

Central Waste Complex . . . . . . . . . . . . . . . . . . . . . . . . . . . . . 16

Double-Shell Tank System . . . . . . . . . . . . . . . . . . . . . . . . . 17

Grout Treatment Facility . . . . . . . . . . . . . . . . . . 18

Hanford Waste Vitrification Plant . . . . . . . . . . . . . . . . . . . . . . . . . . 19

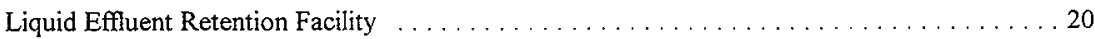

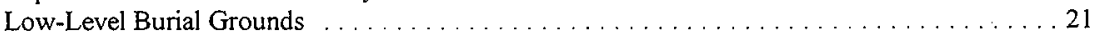

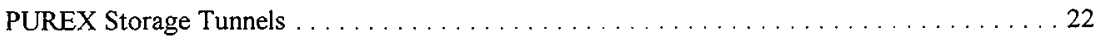

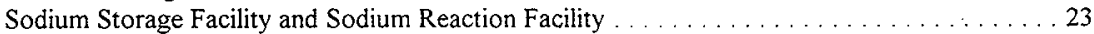

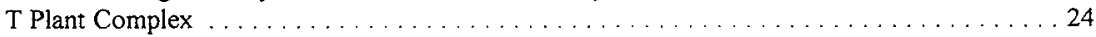

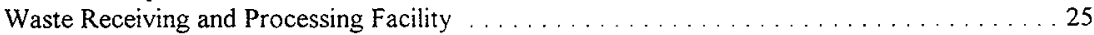

\section{RESOURCE CONSERVATION AND RECOVERY ACT WITHDRAWAL REQUESTS AND PROCEDURAL CLOSURES}

221-T Containment Systems Test Facility . . . . . . . . . . . . . . . . . . . 29

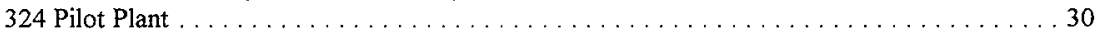

332 Storage Facility . . . . . . . . . . . . . . . . . . . . . . . . . 31

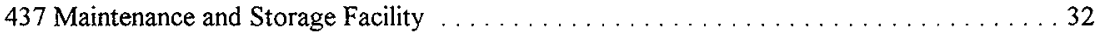

1706-KE Waste Treatment System . . . . . . . . . . . . . . . . . . . . . . . 33

2727-WA Sodium Reactor Experiment Sodium Storage Building $\ldots \ldots \ldots \ldots \ldots \ldots . \ldots 34$

Biological Treatment Test Facilities . . . . . . . . . . . . . . . . . . . . . . . . 35 


\section{RESOURCE CONSERVATION AND RECOVERY ACT PROCEDURAL CLOSURE PERMITTING (cont.)}

Physical and Chemical Treatment Test Facilities . . . . . . . . . . . . . . . . 36

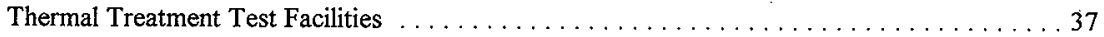

\section{RESOURCE CONSERVATION AND RECOVERY ACT RESEARCH, DEVELOPMENT, AND DEMONSTRATION PERMITTING}

Waste Water Pilot Plant

\section{TOXIC SUBSTANCES CONTROL ACT PERMITTING}

Low-Level Burial Grounds

\section{RESOURCE CONSERVATION AND RECOVERY ACT CLOSURE PLANS}

100-D Ponds

105-DR Large Sodium Fire Facility

200 West Area Ash Pit Demolition Site . . . . . . . . . . . . . . . . . . . . . . 51

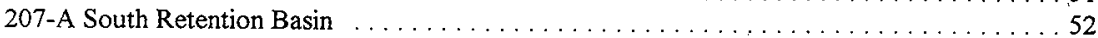

216-B-3 Expansion Ponds . . . . . . . . . . . . . . . . . . . . . . . . . . 53

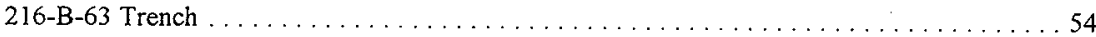

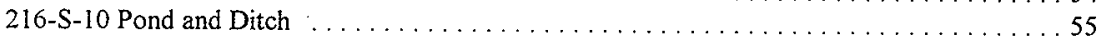

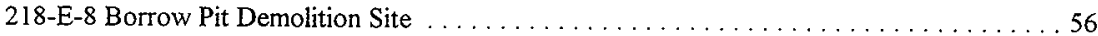

300 Area Solvent Evaporator . . . . . . . . . . . . . . . . . . . . . . . . . . 57

300 Area Waste Acid Treatment System . . . . . . . . . . . . . . . . . . . . 58

$303-\mathrm{K}$ Storage Facility . . . . . . . . . . . . . . . . . . . . . . . . . . . . . . 59

$303-\mathrm{M}$ Oxide Facility . . . . . . . . . . . . . . . . . . . . . . . . . 60

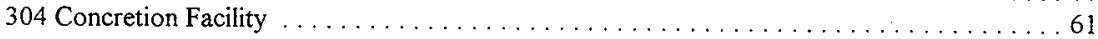

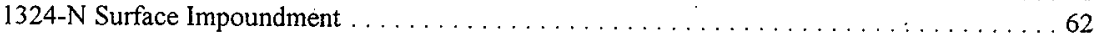

1324-NA Percolation Pond . . . . . . . . . . . . . . . . . . . . . . . . . 63

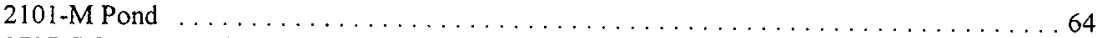

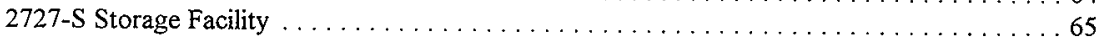

3718-F Alkali Metal Treatment and Storage Facility . . . . . . . . . . . . . . . . 66

4843 Alkali Metal Storage Facility . . . . . . . . . . . . . . . . . . . . . . . . 67

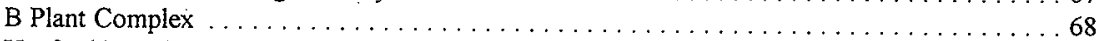

Hanford Patrol Academy Demolition Sites . . . . . . . . . . . . . . . . . . . . . 69

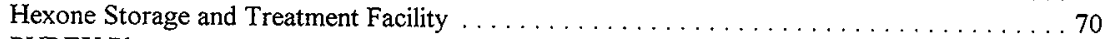

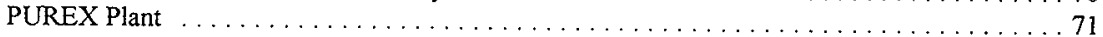

Simulated High-Level Waste Slurry Treatment/Storage $\ldots \ldots \ldots \ldots \ldots \ldots \ldots \ldots \ldots \ldots \ldots$ 


\section{RESOURCE CONSERVATION AND RECOVERY ACT CLOSURE AND POSTCLOSURE PLANS}

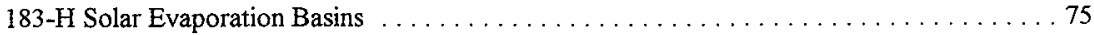

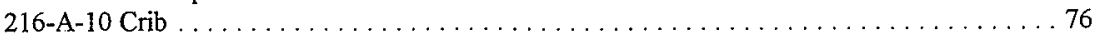

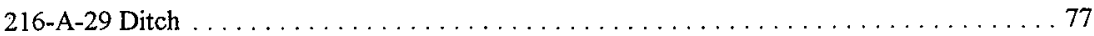

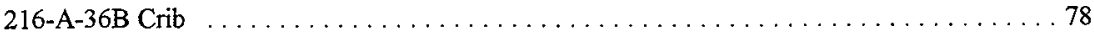

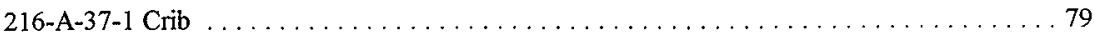

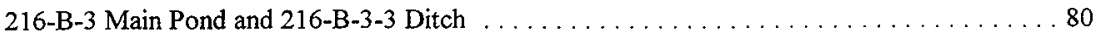

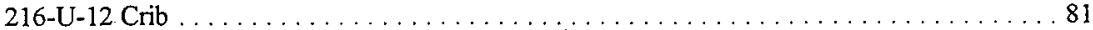

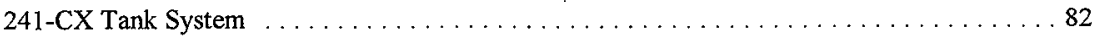

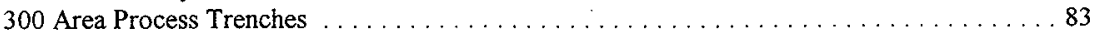

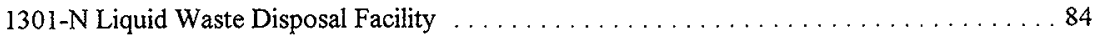

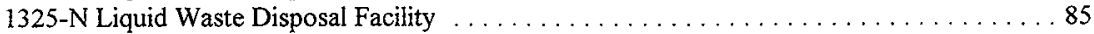

Nonradioactive Dangerous Waste Landfill $\ldots \ldots \ldots \ldots \ldots \ldots \ldots \ldots \ldots \ldots$

\section{RESOURCE CONSERVATION AND RECOVERY ACT CLOSURE WORK PLAN}

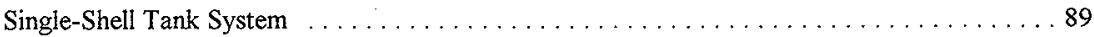

\section{RESOURCE CONSERVATION AND RECOVERY ACT DELISTING PETITION}

200 Area Effluent Treatment Facility 93

\section{SOLID WASTE HANDLING PERMITTING}

Solid Waste Landfill

\section{CLEAN AIR ACT PERMITTING}

Hanford Site (Radioactive Air Emissions Program) . . . . . . . . . . . . . . . . . . 101

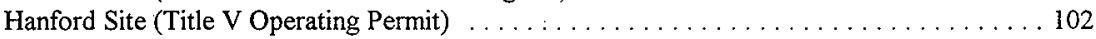

100-K Basins Dose Reduction Activities . . . . . . . . . . . . . . . . . . . 103

100-K Basins Phase 2 Characterization . . . . . . . . . . . . . . . . . . . . . . . . . 104

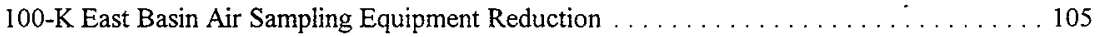

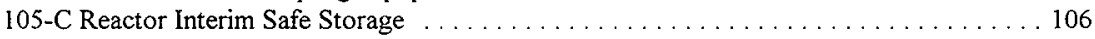

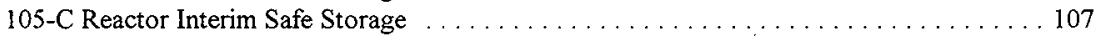

105-K East and 105-K West Basin Entryway Modifications . . . . . . . . . . . . . 108

105-K East and 105-K West Corridor 7 Modifications . . . . . . . . . . . . . . . . . 109 


\section{CLEAN AIR ACT PERMITTING (cont.)}

105-K East and 105-K West Entrance Vestibule Modifications . . . . . . . . . . . . . 111

105-K East and 105-K West Fuel Hangar Removal Activity . . . . . . . . . . . . 112

105-K East Basin . . . . . . . . . . . . . . . . . . . . . . . . . . . . . . 113

105-K East Basin Chiller and Heat Exchanger Removal Activity . . . . . . . . . . . . 114

105-K East Basin Debris Removal . . . . . . . . . . . . . . . . . . . . . . . . . 115

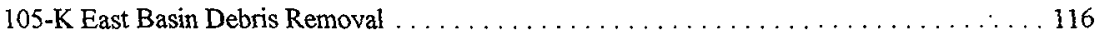

105-K East Basin Hydrolasing . . . . . . . . . . . . . . . . . . . . . . . 117

$105-\mathrm{K}$ East Basin Hydrolasing . . . . . . . . . . . . . . . . . . . . . . . 118

105-K West Basin Corridor Modification . . . . . . . . . . . . . . . . . . . . . . 119

105-K West Basin Sludge Pumping from the South Loadout Pit $\ldots \ldots \ldots \ldots \ldots \ldots \ldots$

105-K West Demolition Activities . . . . . . . . . . . . . . . . . . . . . . . . . . . . 121

200 Area Diesel Generators . . . . . . . . . . . . . . . . . . . . . . . . . . . . . . 122

200 Area Effluent Treatment Facility . . . . . . . . . . . . . . . . . . . . 123

200 Area Effluent Treatment Facility and the Liquid Effluent Retention Facility . . . . . . . 124

200 Area Effluent Treatment Facility Load-In Station and Liquid Effluent Retention

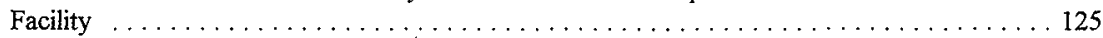

219-S Sample Gallery to 204-AR Waste Unloading Station Waste Transfers . . . . . . . . 126

222-S Laboratory Complex . . . . . . . . . . . . . . . . . . . . . . . . . . . . . 127

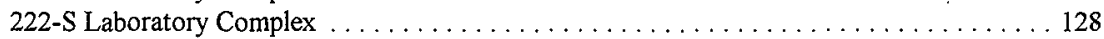

222-S Laboratory Complex . . . . . . . . . . . . . . . . . . . . . . . . . . . . . . . . . . . . . . . 129

222-S Laboratory Complex . . . . . . . . . . . . . . . . . . . . . . . . . . . . . . 130

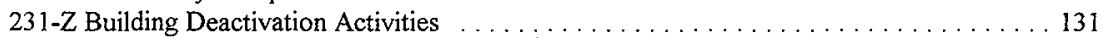

232-Z Building Modification . . . . . . . . . . . . . . . . . . . . . 132

232-Z Building Modification . . . . . . . . . . . . . . . . . . . . . . . . . . . 133

234-5-Z Muffle Furnaces . . . . . . . . . . . . . . . . . . . . . . . . 134

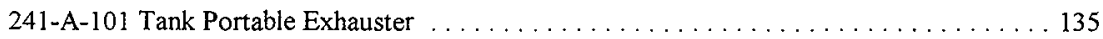

241-A-101 Tank Portable Exhauster .............................. 136

241-A-101 Tank Portable Exhauster ............................. 137

241-AZ-101 Tank Waste Retrieval and 241-AY/241-AZ Tank Farms Ventilation

Upgrades . . . . . . . . . . . . . . . . . . . . . . . . . . . . . . . . 138

241-AZ-101 Tank Waste Retrieval and 241-AY/241-AZ Tank Farms Ventilation

Upgrades . . . . . . . . . . . . . . . . . . . . . . . . . . . . . . . . . . . . . . . . 139

241-AZ-101 Tank Waste Retrieval and 241-AY/241-AZ Tank: Farms Ventilation

Upgrades . . . . . . . . . . . . . . . . . . . . . . . . . . . . . . . . . . . . . . . . 140

241-C-106 Tank Sluicing .................................... 141

241-C-106 Tank Sluicing, Phase II . . . . . . . . . . . . . . . . . . . 142

241-C-106 Tank Sluicing . . . . . . . . . . . . . . . . . . . . . . . . . . . 143

241-SY-101 Tank Mixer Pump Replacement . . . . . . . . . . . . . . . . . . . . . . . . . 144

241-SY-101 Tank Mixer Pump Replacement . . . . . . . . . . . . . . . . . . . . . 145

244-AR Vault Portable Exhauster . . . . . . . . . . . . . . . . . . . . . . . . . . . . 146

244-AR Vault Portable Exhauster . . . . . . . . . . . . . . . . . . . . . . . . . . . . . . . 147

244-CR Vault Double-Contained Receiver Tank . . . . . . . . . . . . . . . . . . . . 148 


\section{CLEAN AIR ACT PERMITTING (cont.)}

244-U Double-Contained Receiver Tank . . . . . . . . . . . . . . . . . . . . . . . . . 149

244-U Double-Contained Receiver Tank . . . . . . . . . . . . . . . . . . . . . . . . . . . 150

300 Area Fuel Supply Shutdown Facilities . . . . . . . . . . . . . . . . 151

305-B Storage Facility . . . . . . . . . . . . . . . . . . . . . . . . . 152

313 Facility Uranium-Bearing System Removal . . . . . . . . . . . . . . . . . . . . . 153

318 Building High-Efficiency Particulate Air Filter Removal . . . . . . . . . . . . . . 154

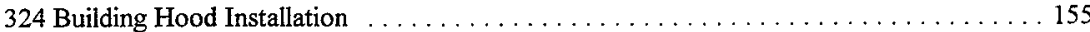

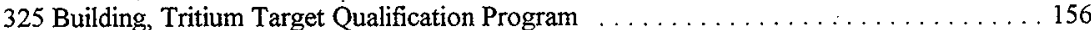

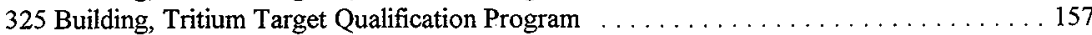

331 High-Efficiency Particulate Air Filter Bank Removal $\ldots \ldots \ldots \ldots \ldots \ldots \ldots \ldots \ldots$

340-NT-EX Emissions Unit . . . . . . . . . . . . . . . . . . . . . . . . . . . . . . . . . . . 159

Applied Chemistry, 325 Building . . . . . . . . . . . . . . . . . . . . . 160

Applied Chemistry, 325 Building . . . . . . . . . . . . . . . . . . . 161

B Plant Canyon Exhaust Tunnel and D-Cell Video Inspection and Dose Measurements . . . . . 162

B Plant Organic Transfer Process and Storage System . . . . . . . . . . . . . . . 163

B Plant Transition Activities . . . . . . . . . . . . . . . . . . . . . . . . . 164

Canister Storage Building Phase I . . . . . . . . . . . . . . . . . . . . . . . . . 165

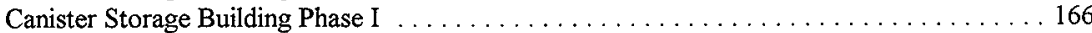

Central Waste Complex and Enhanced Radioactive and Mixed Waste Storage, Phase V . . . 167

Chemical Sciences Laboratory, 329 Building . . . . . . . . . . . . . . . . . . . . . . . 168

Chemical Sciences Laboratory, 329 Building . . . . . . . . . . . . . . . . . . . . . . 169

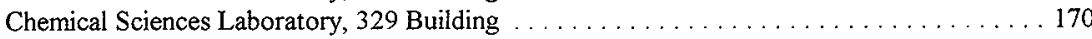

Cold Vacuum Drying Facility . . . . . . . . . . . . . . . . . . . . . . . . . 171

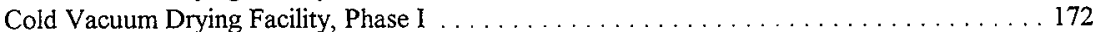

Cold Vacuum Drying Facility, Phase II . . . . . . . . . . . . . . . . . . 173

Emergency Dump Basin . . . . . . . . . . . . . . . . . . . . . . . . . . . 174

Emergency Dump Basin . . . . . . . . . . . . . . . . . . . . . . . . . . 175

Environmental Analytical Laboratory . . . . . . . . . . . . . . . . . . . . . . . 176

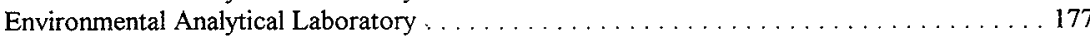

Environmental Analytical Laboratory . . . . . . . . . . . . . . . . . . . . . . 178

Environmental Molecular Sciences Laboratory . . . . . . . . . . . . . . . . . . . . . . . . . . . 179

Environmental Molecular Sciences Laboratory $\ldots \ldots \ldots \ldots \ldots \ldots \ldots \ldots \ldots \ldots \ldots$

Environmental Molecular Sciences Laboratory $\ldots \ldots \ldots \ldots \ldots \ldots \ldots \ldots \ldots \ldots \ldots, 181$

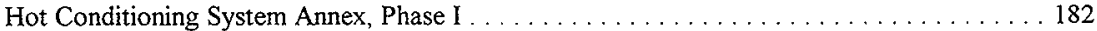

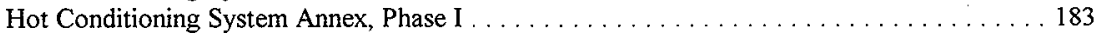

Inactive Miscellaneous Underground Storage Tanks Sampling/Characterization . . . . . . . . 184

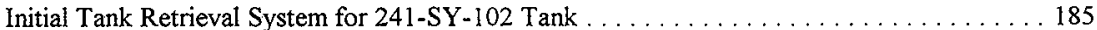

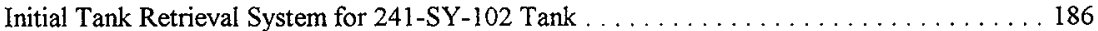

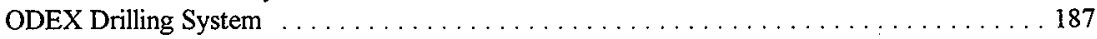

Operation of Portable Exhauster in Conjunction with the Light Duty Utility Arm . . . . . . 188

Operation of a Portable Exhauster in Conjunction with the Light Duty Utility Arm . . . . . . 189

Plasma Arc Furnace, 324 Building . . . . . . . . . . . . . . . . . . . . . . 190 


\section{CLEAN AIR ACT PERMITTING (cont.)}

Plasma Arc Furnace, 324 Building

Plasma Arc Furnace, 324 Building

Plutonium Finishing Plant Cementation of Plutonium Bearing Materials . . . . . . . . . . . 193

Plutonium Finishing Plant Duct Work and Process Piping Remediation . . . . . . . . . . . . 194

Plutonium Finishing Plant Ductwork and Process Piping Remediation . . . . . . . . . . . . . 195

Plutonium Finishing Plant Low-Level Waste Treatment Facility . . . . . . . . . . . . . . . . . 196

Portable Exhausters

Portable Exhauster for Flammable Watchlist Single-Shell Tank System . . . . . . . . . . . . . 198

Portable Exhauster for Flammable Watchlist Single-Shell Tank System . . . . . . . . . . . . . . 199

PUREX Plant Deactivation . . . . . . . . . . . . . . . . . . . . . . . . . . . . . . . 200

Radon Research Facility, 331 Building . . . . . . . . . . . . . . . . . . . . . . 201

Radon Research Facility, 331 Building . . . . . . . . . . . . . . . . . . . . . . . . . 202

Radon Research Facility Relocation to Any Location Onsite . . . . . . . . . . . . . . . . 203

Rotary Mode Core-Sampling System Two . . . . . . . . . . . . . . . . . . . . . . . . . . . . . 204

Rotary Mode Core Sampling System Two . . . . . . . . . . . . . . . . . . . . . . 205

Rotary Mode Core Sampling System Two . . . . . . . . . . . . . . . . . . . . . . 206

Rotary Mode Core-Sampling Systems Three and Four . . . . . . . . . . . . . . . . . . . . . . . 207

Rotary Mode Core Sampling Systems Three and Four . . . . . . . . . . . . . . . . . . . 208

Rotary Mode Core Sampling Systems Three and Four, and Modification of Rotary

Mode Core Sampling System Two . . . . . . . . . . . . . . . . . . . . . . . . . . . . . . . . . . . 209

Routine, Exempt and Approved Tank Farm Activities . . . . . . . . . . . . . . . . . . . 210

Single-Shell Tanks Portable Exhauster for Salt Well Pumping and Other Activities

(Minor Emission Point)

Single-Shell Tanks Portable Exhauster for Salt Well Pumping and Other Activities

(Minor Emission Point) . . . . . . . . . . . . . . . . . . . . . . . . . . . . . 212

Single-Shell Tanks Portable Exhauster for Salt Well Pumping and Other Activities . . . . . . 213

Sodium Storage Facility . . . . . . . . . . . . . . . . . . . . . . . . . . . . . 214

Sodium Storage Facility . . . . . . . . . . . . . . . . . . . . . . 215

Stabilization of Plutonium Metal Oxides in Muffle Furnaces at the Plutonium Finishing

Plant

Stabilization of Plutonium Metal Oxides in Muffle Furnaces at the Plutonium Finishing

Plant

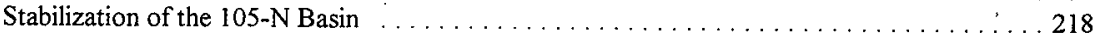

Stabilization of the $105-\mathrm{N}$ Basin . . . . . . . . . . . . . . . . . . . . . . . . . . . . . . 219

Steam Plant Rehabilitation, Phase II . . . . . . . . . . . . . . . . . . . . . . 220

Storage of the Liquid Waste Tank Cars and the 324 Building Waste in the PUREX

Storage Tunnel Number 2

Storage of the Liquid Waste Tank Cars and the 324 Building Waste in the PUREX

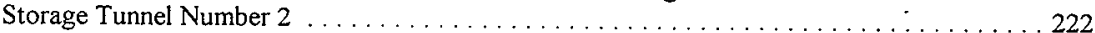

T Plant Complex Secondary Containment and Leak Detection Upgrades, Project W-259 . . . 223

T Plant Complex Secondary Containment and Leak Detection Upgrades, Project W-259 . . . 224

T Plant Complex--Eurociean HEPA-filtered vacuums to be used for contamination

control and in waste handling activities 


\section{CLEAN AIR ACT PERMITTING (cont.)}

Transfer and Receipt of Waste in the 324 Building for Storage in PUREX Storage

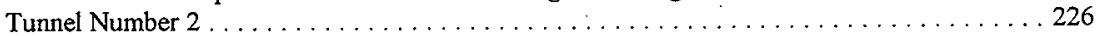

Transfer and Receipt of Waste in the 324 Building for Storage in PUREX Storage

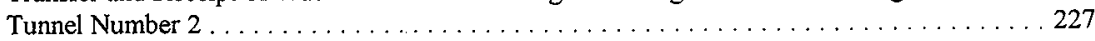

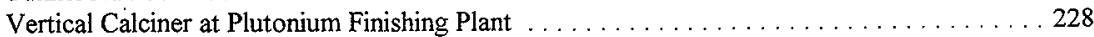

Waste Encapsulation and Storage Facility K-3 Duct Characterization . . . . . . . . . . . 229

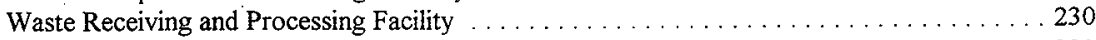

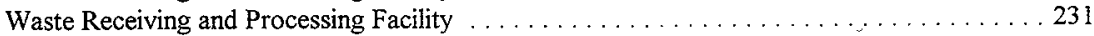

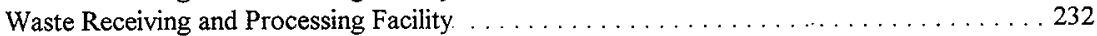

Waste Receiving and Processing Facility Stack No. 296-W-004 Monitoring System

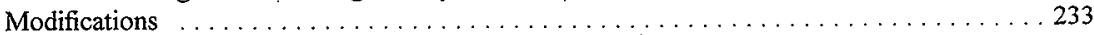

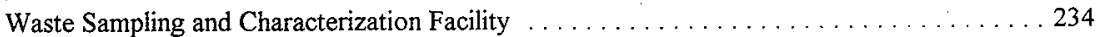

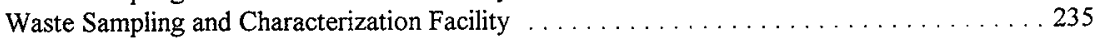

Water/Sediment Removal from 107-N, 1310-N, and 1314-N Facilities . . . . . . . . 236

Water/Sediment Removal from 107-N, 1310-N, and 1314-N Facilities . ............ 237

\section{CLEAN WATER ACT PERMITTING}

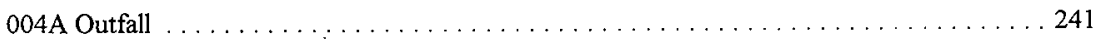

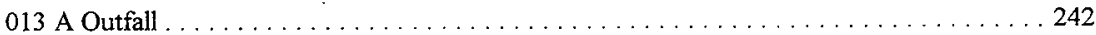

$005,006,007,009$, and $N$ Springs Outfalls ......................... 243

300 Area Treated Effluent Disposal Facility, Project L-045H . . . . . . . . . . . . . 244

300 Area Treated Effluent Disposal Facility, Project L-045H . . . . . . . . . . . . . 245

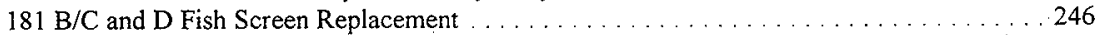

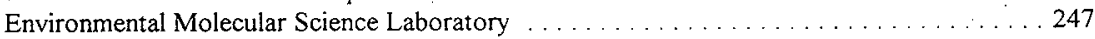

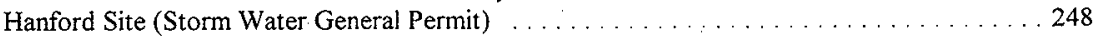

\section{NATIONAL PARK SERVICE REVIEW PERMITTING}

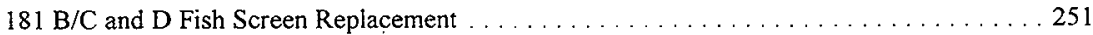

\section{AQUATIC LANDS LEASE PERMITTING}

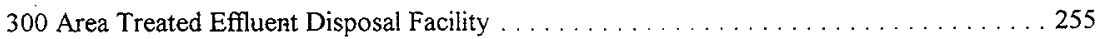




\section{HYDRAULIC PROJECT APPROVAL PERMITTING}

$181 \mathrm{~B} / \mathrm{C}$ and D Fish Screen Replacement . . . . . . . . . . . . . . . . . . . . . . 259

$181-\mathrm{K}$ East Fish Screen Replacement . . . . . . . . . . . . . . . . . . . . . . . 260

\section{WATER QUALITY STANDARDS MODIFICATION PERMITTING}

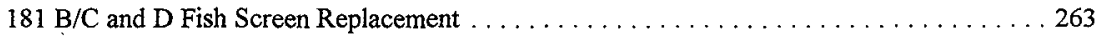

181-K Fish Screen Replacement . . . . . . . . . . . . . . . . . . . . . . . . . . . . . 264

\section{STATE WASTE DISCHARGE PERMITTING}

100-N Sewage Lagoon . . . . . . . . . . . . . . . . . . . . . . . . . . . . . 267

183-N Backwash Discharge Pond ............................. 268

200 Area Effluent Treatment Facility . . . . . . . . . . . . . . . . . . . . . . . . . 269

200 Area Treated Effluent Disposal Facility . . . . . . . . . . . . . . . . . . . . 270

400 Area Secondary Cooling Water . . . . . . . . . . . . . . . . . . . . . 271

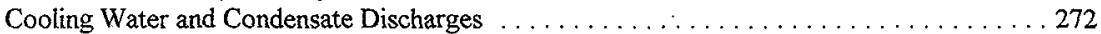

Hydrotesting, Construction, and Maintenance Discharges $\ldots \ldots \ldots \ldots \ldots \ldots \ldots \ldots 273$

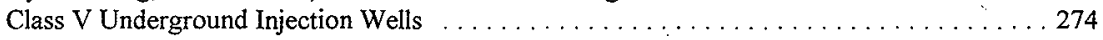

\section{ONSITE SEWAGE SYSTEM PERMITTING}

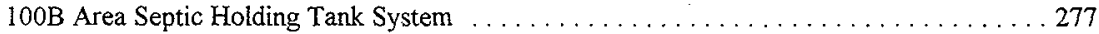

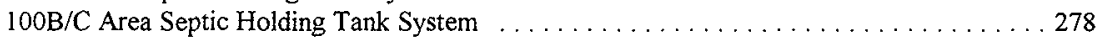

100D Area Septic Holding Tank System . . . . . . . . . . . . . . . . . . . . . 279

183-KE Septic Holding Tank . ............................ 280

2750-E and Adjacent Facilities Septic System . . . . . . . . . . . . . . . . . 281

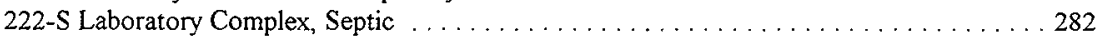

1607.K4 Septic Tank . . . . . . . . . . . . . . . . . . . . . . . . . . . . . . . . . . . 283

2607-EP Septic Tank . . . . . . . . . . . . . . . . . . . . . . . . . . . . . . . . . . . 284 284

2607-EQ Septic Tank . . . . . . . . . . . . . . . . . . . . . . . . . 285

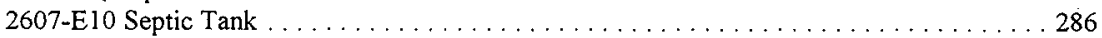

2607-E12 Septic Tank . . . . . . . . . . . . . . . . . . . . . . . . . . . . . . . . . . . . . 287

2607-WA East Septic Tank ....... . . . . . . . . . . . . . . . . . . . . . . 288

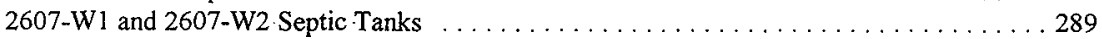

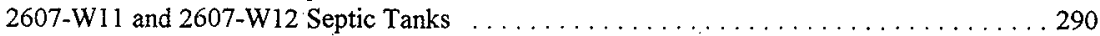

2607-W14 Septic Tank . . . . . . . . . . . . . . . . . . . . . . . . . . . . . . . . . . . 291

2607-W15 Septic Tank . . . . . . . . . . . . . . . . . . . . . . . . . . . . . . 292

$6607-9$ Septic Tank . . . . . . . . . . . . . . . . . . . . . . . . . . . . . . . . . . . . 293

6607-11 Septic Tank . . . . . . . . . . . . . . . . . . . . . . . . . . . . . . . . . . . . . 294

6607-16 Septic Tank ....................................... 295 


\section{ONSITE SEWAGE SYSTEM PERMITTING (cont.)}

$6607-17$ Septic Tank . . . . . . . . . . . . . . . . . . . . . . . . . . 296

Environmental Molecular Sciences Laboratory Temporary Septic Holding Tank . . . . . . . 297

Environmental Restoration Disposal Facility Construction Trailer Septic Holding Tank

System . . . . . . . . . . . . . . . . . . . . . . . . . . . . . . . . . . . . . 298

Environmental Restoration Disposal Facility Septic Holding Tank . . . . . . . . . . . . . 299

Environmental Restoration Disposal Facility Shop Facility Septic Holding Tank . . . . . . 300

\section{PETROLEUM UNDERGROUND STORAGE TANK PERMITTING}

100B Area, 181B-66 Tank . . . . . . . . . . . . . . . . . . . . . 303

200 East Area, $204-$ AR Tank . . . . . . . . . . . . . . . . . . . . . . . 304

200 East Area, $241-A-701-1$ Tank . . . . . . . . . . . . . . . . . . . . 305

200 East Area, $241-A-701-2$ Tank . . . . . . . . . . . . . . . . . . . 306

200 East Area, $242-A-1$ Tank ................................ 307

200 East Area, $244-$ AR Tank . . . . . . . . . . . . . . . . . . . . . . . 308

200 East Area, $2711-66$ Tank . . . . . . . . . . . . . . . . . . . . . . . . 309

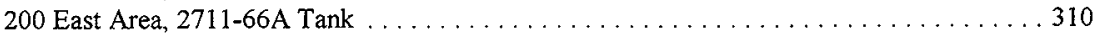

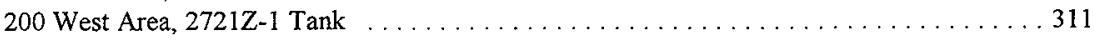

200 West Area, 2736ZA-1 Tank . . . . . . . . . . . . . . . . . . . . . . . . 312

300 Area, $3621-\mathrm{C}$ Tank . . . . . . . . . . . . . . . . . . . . . . . . . 313

300 Area, $3621-66$ Tank . . . . . . . . . . . . . . . . . . . . . . . 314

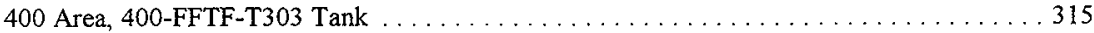

600 Area, $6291-66$ Tank . . . . . . . . . . . . . . . . . . . . . . . 316

600 Area, $6291-66$ A Tank . . . . . . . . . . . . . . . . . . . . . . . . 317

1100 Area, $1172-66$ Tank . . . . . . . . . . . . . . . . . . . . . 318

1100 Area, $1172-66$ A Tank . . . . . . . . . . . . . . . . . . . . . . . 319

\section{REFERENCES}

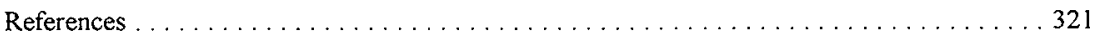




\section{ACRONYMS}

CFR

DOE

DOE-RL

DW

Ecology

EPA

HF RCRA Permit

HSWA

N/A

NESHAPS

NPDES

PSD

PUREX

RCRA

RD\&D

TBD

Tri-Party Agreement

TSCA

TSD

WAC

WPPSS
Code of Federal Regulations

U.S: Department of Energy

U.S. Department of Energy, Richland Operations Office dangerous waste

Washington State Department of Ecology

U.S. Environmental Protection Àgency

Hanford Facility RCRA-Permit

Hazardous and Solid Waste Amendments of 1984

not applicable

National Emission Standards for Hazardous Air Pollutants

National Pollutant Discharge Elimination System

Prevention of Significant Deterioration

plutonium-uranium extraction

Resource Conservation and Recovery Act of 1976

research, development, and demonstration

to be determined

Hanford Federal Facility Agreement and Consent Order

Toxic Substances Control Act of 1976

treatment, storage, and/or disposal

Washington Administrative Code

Washington Public Power Supply System 
DOE/RL-96-63, Rev. 1

$10 / 97$

\section{RESOURCE CONSERVATION AND RECOVERY ACT PERMTTTING}


This page intentionally left blank. 
DOE/RL-96-63, Rev. 1

$10 / 97$

PART A AND PART B PERMITTING 
DOE/RL-96-63, Rev. 1

This page intentionally left blank. 
DOE Operations Office: Richland

DOE Facility: Hanford Site

Existing Permit (X) Renewal ( ) New Permit ( )

Permit Type: RCRA

Permitting Agency: Washington State Department of Ecology

Permit Number: WA7890008967

Permitted Unit: Hanford Facility RCRA Permit

Issuance Date: September 28, 1994

Expiration Date: September 27, 2004

Need for Headquarters' Action

(for permit renewals or new permits)
Yes ( ) No (X)

If yes, HQ Program Element

Brief Summary of Relevant Information (major permit conditions, status of compliance or unusual problems):

The initial HF RCRA Permit (Revision 0) was issued by Ecology and the EPA on August 29, 1994, and became effective on September 28, 1994. The HF RCRA Permit governs all final status treatment, storage, and/or disposal (TSD) activities on the Hanford Facility. Revision 0 of the HF RCRA Permit (DW Portion) incorporated five TSD units. Revision 1 of the HF RCRA Permit (DW Portion) became effective on May 29, 1995, and incorporated five additional TSD units. Revision 2 of the HF RCRA Permit (DW Portion) became effective on September 28, 1995, and incorporated three additional TSD units. Revision 3. of the HF RCRA Permit (DW Portion) became effective on December 26, 1996, and incorporated five additional TSD units. Revision 3A (April 16, 1997) provided corrections to Revision 3 and maintained the same effective date.

The permit is a single application organized into a General Information Portion (GIP) and the UnitSpecific Portion discussed in the previous paragraph. The purpose of the GIP. is to provide an overview of the Hanford Facility and to provide general information for all units to aid in the permitting process. Revision 3 of the GIP (DOE 1997) incorporated into Revision 3 of the HF RCRA Permit contains information current through January 1, 1997.

Compiled by: Waste Management Federal Services of Hanford, Inc.

Date: July 31,1997 for Fluor Daniel Hanford, Inc. 
DOE Operations Office: Richland

DOE Facility: Hanford Site

Existing Permit ( ) Renewal ( ) New Permit (X)

Permit Type: RCRA

Permitting Agency: Washington State Department of Ecology

Permit Number: WA7890008967

Permitted Unit: 200 Area Effluent Treatment Facility

Issuance Date:

Expiration Date:

Need for Headquarters' Action

(for permit renewals or new permits)
Yes ( ) No (X)

If yes, HQ Program Element

Brief Summary of Relevant Information (major permit conditions, status of compliance or unusual problems):

Part A, Form 3, dangerous waste permit application documentation for the 200 Area Effluent Treatment Facility (ETF) originally was submitted to Ecology and the EPA in June 1991. Two revisions of the Part A, Form 3, dangerous waste permit application documentation has been submitted.

Tri-Party Agreement Milestone M-20-50 was satisfied with the submittal of the Part B dangerous waste permit application documentation to Ecology and the EPA on August 31, 1993. Subsequently, the 200 Area ETF and Liquid Effluent Retention Facility Part B dangerous waste permit applications were combined into one Part $B$ permit application, Revision O. The LERF and ETF permit application is scheduled for incorporation into the HF RCRA Permit (DW Portion) in Modification C, December 1997.

Compiled by: Waste Management Federal Services of Hanford, Inc.

Date: July 31, 1997 for Fluor Daniel Hanford, Inc. 
DOE Operations Office: Richland

DOE Facility: Hanford Site

Existing Permit ( ) Renewal ( ) New Permit (X)

Permit Type: RCRA

Permitting Agency: Washington State Department of Ecology

Permit Number: WA7890008967

Permitted Unit: 204-AR Waste Unloading Station

Issuance Date:

Expiration Date:

Need for Headquarters' Action

(for permit renewals or new permits)
Yes ( ) No (X)

If yes, HQ Program Element

Brief Summary of Relevant Information (major permit conditions, status of compliance or unusual problems):

Part A, Form 3, dangerous waste permit application documentation for the 204-AR Waste Unloading Station originally was submitted to Ecology and the EPA in November 1987. Four revisions of the Part A, Form 3, dangerous waste permit application documentation have been submitted.

The 204-AR Waste Unloading Station will be added to Revision 1 of the Hanford Facility Dangerous Waste Permit Application, Double-Shell Tank System documentation. The Double-Shell Tank System is scheduled to be incorporated into the HF RCRA Permit (DW Portion) in Modification E; calendar year 1999.

Compiled by: Waste Management Federal Services of Hanford, Inc. for Fluor Daniel Hanford, Inc.

Date: July 31, 1997 
DOE Operations Office: Richland

DOE Facility: Hanford Site

Existing Permit ( ) Renewal ( ) N New Permit (X)

Permit Type: RCRA

Permitting Agency: Washington State Department of Ecology

Permit Number: WA7890008967

Permitted Unit: 222-S Laboratory Complex

Issuance Date:

Expiration Date:

Need for Headquarters' Action

(for permit renewals or new permits)
Yes ( ) No (X)

If yes, HQ Program Element

Brief Summary of Relevant Information (major permit conditions, status of compliance or unusual problems):

Part A, Form 3, dangerous waste permit application documentation for the 222-S Laboratory Complex originally was submitted to Ecology and the EPA on November 25,1987 . Five revisions of the Part A, Form 3, dangerous waste permit application documentation have been submitted.

Tri-Party Agreement Milestone M-20-22 was satisfied with the submittal of the Part B dangerous waste permit application documentation to Ecology and the EPA in December 1991. All Notice of Deficiency comments received from the regulators have been resolved. The 222-S Laboratory Complex is scheduled to be incorporated into the HF RCRA Permit (DW Portion) in Modification E, calendar year 1999 .

Compiled by: Waste Management Federal Services of Hanford, Inc.

Date: July 31, 1997 for Fluor Daniel Hanford, Inc. 
DOE Operations Office: Richland

DOE Facility: Hanford Site

Existing Permit ( ) Renewal ( ) New Permit (X)

Permit Type: RCRA

Permitting Agency: Washington State Department of Ecology

Permit Number: WA7890008967

Permitted Unit: 224-T Transuranic Waste Storage and Assay Facility

Issuance Date:

Expiration Date:

Need for Headquarters' Action

(for permit renewals or new permits)
Yes ( ) No ( $\mathrm{X}$ )

If yes, HQ Program Element

Brief Summary of Relevant Information (major permit conditions, status of compliance or unisual problems):

Part A, Form 3, dangerous waste permit application documentation for the 224-T Transuranic Waste Storage and Assay Facility (TRUSAF) originally was submitted to Ecology and the EPA in November 1987. Six revisions of the Part A. Form 3, dangerous waste permit application documentation have been submitted.

Tri-Party Agreement Milestone M-20-23 was satisfied with the submittal of the Part B dangerous waste permit application documentation to Ecology and the EPA in June 1992. Notice of Deficiency comments were received from Ecology on January 27. 1994. The Notice of Deficiency response table was submitted to Ecology on May 26, 1994. The Notice of Deficiency response table is under review by the regulators. Ecology has not responded to this submittal. A request was made during the quarter ending March 31, 1997. for a Class I Modification to the HF RCRA Permit. This request changed the submittal of 224-T TRUSAF Part B dangerous waste permit application documentation during Modification E to submittal of a 224-T TRUSAF Closure Plan during Modification D, calendar year 1998, pending approval by Ecology.

Compiled by: Waste Management Federal Services of Hanford, Inc.

Date: July 31, 1997 for Fluor Daniel Hanford, Inc. 
DOE Operations Office: Richland

DOE Facility: Hanford Site

Existing Permit ( ) Renewal ( ) New Permit (X)

Permit Type: RCRA

Permitting Agency: Washington State Department of Ecology

Permit Number: WA7890008967

Permitted Unit: $241-Z$ Treatment and Storage Tanks

Issuance Date:

Expiration Date:

Need for Headquarters ${ }^{t}$ Action

(for permit renewals or new permits)
Yes ( ) No (X)

If yes, HQ Program Element

Brief Summary of Relevant Information (major permit conditions, status of compliance or unusual problems):

Part A, Form 3, dangerous waste permit application documentation for the 241-Z Treatment Tank originally was submitted to Ecology and the EPA in November 1987. Five revisions of the Part A. Form 3, dangerous waste permit application documentation have been submitted.

Tri-Party Agreement Milestone M-20-48 originally required submittal of the Part B dangerous waste permit application documentation for the 241-Z Treatment and Storage Tanks to Ecology by May 31, 1996. Renegotiated Milestone M-20-48A replaced Milestone M-20-48 and a closure plan was submitted to Ecology on December 27, 1996. A schedule for including this closure in the HF RCRA Permit has not been defined.

Compiled by: Waste Management Federal Services of Hanford, Inc.

Date: July 3I, 1997

for Fluor Daniel Hanford, Inc. 
DOE Operations Office: Richland

DOE Facility: Hanford Site

Existing Permit ( ) Renewal ( ) New.Permit (X)

Permit Type: RCRA

Permitting Agency: Washington State Department of Ecology

Permit Number: WA7890008967

Permitted Unit: 242-A Evaporator

Issuance Date:

Expiration Date:

Need for Headquarters' Action

(for permit renewals or new permits)
Yes ( ) No (X)

If yes, HQ Program Element

Brief Summary of Relevant Information (major permit conditions, status of compliance or unusual problems):

Part A, Form 3, dangerous waste permit application documentation for the 242-A Evaporator originally was submitted to Ecology and the EPA in September 1987. Seven revisions of the Part A, Form 3, dangerous waste permit application documentation have been submitted.

Tri-Party Agreement Milestone M-20-17 was satisfied with the submittal of the Part B dangerous waste permit application documentation to Ecology and the EPA in June 1991. The 242-A Evaporator Part B dangerous waste permit application documentation, Revision I, is scheduled for incorporation into the HF RCRA Permit (DW Portion) in Modification C, December 1997.

Compiled by: Waste Management Federal Services of Hanford, Inc.

Date: July 31, 1997 for Fluor Daniel Hanford, Inc. 
DOE Operations Office: Richland

DOE Facility: Hanford Site

Existing Permit (X) Renewal ( ) New Permit ( )

Permit Type: RCRA

Permitting Agency: Washington State Department of Ecology

Permit Number: WA7890008967

Permitted Unit: 305-B Storage Unit

Issuance Date: September 28, 1994

Expiration Date: September 27, 2004

Need for Headquarters' Action

Yes ( ) No (X)

(for permit renewals or new permits)

If yes, HQ Program Element

Brief Summary of Relevant Information (major permit conditions, status of compliance or unusual problems):

Part A, Form 3, dangerous waste permit application documentation for the 305-B Storage Unit originally was submitted to Ecology and the EPA in May 1988. One revision of the Part A, Form 3, dangerous waste permit application documentation has been submitted.

Tri-Party Agreement Milestone M-20-08 was satisfied with the submittal of the Part B dangerous waste permit application documentation to Ecology and the EPA in January 1990. Revision 2 of the 305-B Storage Unit Part B dangerous waste permit application documentation was incorporated into Revision 0 of the HF RCRA Permit (DW Portion) that became effective on September 28, 1994. Several Class 1 modifications of the application documentation have been submitted quarterly following incorporation of the unit into the HF RCRA Permit (DW Portion).

Compiled by: Pacific Northwest National Laboratory Environmental Protection

Date: July 31, 1997 
DOE Operations Office: Richland

DOE Facility: Hanford Site

Existing Permit ( ) Renewal ( ) New Permit (X)

Permit Type: RCRA

Permitting Agency: Washington State Department of Ecology

Permit Number: WA7890008967

Permitted Unit: 325 Hazardous Waste Treatment Units

Issuance Date:

Expiration Date:

Need for Headquarters' Action

(for permit renewals or new permits)
Yes ( ) No (X)

If yes, HQ Program Element

Brief Summary of Relevant Information (major permit conditions, status of compliance or unusual problems):

Part A, Form 3, dangerous waste permit application documentation for the 325 Hazardous Waste Treatment Units originally was submitted to Ecology and the EPA in May 1988. Four revisions of the Part A, Form 3, dangerous waste permit application documentation have been submitted.

Tri-Party Agreement Milestone M-20-20 was satisfied with the submittal of the Part B dangerous waste permit application documentation to Ecology and the EPA in June 1992. The 325 Shielded Analytical Laboratory activities that operated under the Physical/Chemical Treatment Test Facilities Part A, Form 3, were added to the 325 Hazardous Waste Treatment Units Part A, Form 3, on December 2, 1994. A tank system to collect discharges formerly made to the 300 Area Radioactive Liquid Waste System (RLWS) was added to the permit documentation in 1997. The Part B permit application documentation for this unit was revised to reflect these changes and was submitted to Ecology on June 30, 1997, for incorporation into the HF RCRA Permit (DW Portion) in Modification C, December 1997.

Compiled by: Pacific Northwest National Laboratory

Date: July 31, 1997

Environmental Protection 
DOE Operations Office: Richland

DOE Facility: Hanford Site

Existing Permit ( ) Renewal ( ) New Permit (X)

Permit Type: RCRA

Permitting Agency: Washington State Department of Ecology

Permit Number: WA7890008967

Permitted Unit: 600 Area Purgewater Storage and Treatment Facility

Issuance Date:

Expiration Date:

Need for Headquarters' Action

(for permit renewals or new permits)

\section{Yes ( ) No (X)}

If yes, HQ Program Element

Brief Summary of Relevant Information (major permit conditions, status of compliance or unusual problems):

Part A, Form 3, dangerous waste permit application documentation for the 600 Area Purgewater Storage and Treatment Facility originally was submitted to Ecology and the EPA in February 1990. Two revisions of the Part A. Form 3, dangerous waste permit application documentation have been submitted.

Compiled by: Waste Management Federal Services of Hanford, Inc.

Date: July 31, 1997 for Fluor Daniel Hanford, Inc. 
DOE Operations Office: Richland

DOE Facility: Hanford Site

Existing Permit (X) Renewal ( ) New Permit ( )

Permit Type: RCRA

Permitting Agency: Washington State Department of Ecology

Permit Number: WA7890008967

Permitted Unit: 616 Nonradioactive Dangerous Waste Storage Facility

Issuance Date: September 28, 1994 (Date Revision 0 of the $\mathrm{HF}$ RCRA Pernut became effective. 30 days after permit issuance.)

Expiration Date: September 27, 2004

Need for Headquarters' Action

(for permit renewals or new permits)
Yes ( ) No (X)

If yes, HQ Program Element

Brief Summary of Relevant Information (major permit conditions, status of compliance or unusual problems):

Part A, Form 3, and Part B dangerous waste permit application documentation for the 616 Nonradioactive Dangerous Waste Storage Facility originally was submitted to Ecology and the EPA in November 1985. Seven revisions of the Part A. Form 3, dangerous waste permit application documentation have been submitted.

Tri-Party Agreement Milestone M-20-02 was satisfied with the submittal of the Part B dangerous waste permit application documentation to Ecology and the EPA in July 1989. Revision 2 of the 616 Nonradioactive Dangerous Waste Storage Facility Part B dangerous waste permit application documentation was incorporated into Revision 0 of the HF RCRA Permit (DW Portion) that became effective on September 28, 1994. Several Class 1 modifications have been submitted quarterly and one Class III modification has been submitted following incorporation into the HF RCRA Permit (DW Portion). Revision 3 of the 616 Nonradioactive Dangerous Waste Storage Facility Part B dangerous waste permit application documentation was submitted to Ecology on April 14, 1997. Revision 3 was submitted to incorporate all Class I and the Class III modifications and to change the co-operator of the unit to Fluor Daniel Hanford, Inc. A change in ownership was approved by Ecology as a Class 1 modification.

Compiled by: Waste Management Federal Services of Hanford, Inc.

Date: July 31,1997

for Fluor Daniel Hanford, Inc. 
DOE Operations Office: Richland

DOE Facility: Hanford Site

Existing Permit ( ) Renewal ( ) New Permit (X)

Permit Type: RCRA

Permitting Agency: Washington State Department of Ecology

Permit Number: WA7890008967

Permitted Unit: Central Waste Complex

Issuance Date:

Expiration Date:

Need for Headquarters' Action

(for permit renewals or new permits)
Yes ( ) No (X)

If yes, HQ Program Element

Brief Summary of Relevant Information (major permit conditions, status of compliance or unusual problems):

Part A, Form 3, dangerous waste permit application documentation for the Central Waste Complex originally was submitted to Ecology and the EPA in May 1988. Four revisions of the Part A, Form 3, dangerous waste permit application documentation have been submitted.

Tri-Party Agreement Milestone M-20-05 was satisfied with the submittal of the Part B dangerous waste permit application documentation to Ecology and the EPA in October 1991. A working draft (WD-1) of the Central Waste Complex Part B dangerous waste permit application documentation was submitted to Ecology and the EPA on December 31, 1994 . Working draft (WD-2) was submitted to Ecology in January 1997. Workshops are ongoing with Ecology to finalize Revision 1. The Central Waste Complex is scheduled for incorporation into the HF RCRA Permit (DW Portion) in Modification D, calendar year 1998.

Compiled by: Waste Management Federal Services of Hanford, Inc. for Fluor Daniel Hanford, Inc. 
DOE Operations Office: Richland

DOE Facility: Hanford Site

Existing Permit ( ) Renewal ( ) New Permit (X)

Permit Type: RCRA

Permitting Agency: Washington State Department of Ecology

Permit Number: WA7890008967

Permitted Unit: Double-Shell Tank System

Issuance Date:

Expiration Date:

Need for Headquarters' Action

(for permit renewals or new permits)
Yes ( ) No $(X)$

If yes, HQ Program Element

Brief Summary of Relevant Information (major permit conditions, status of compliance or unusual problems):

Part A, Form 3, dangerous waste permit application documentation for the Double-Shell Tank System originally was submitted to Ecology and the EPA in September 1987. Eight revisions of the Part A. Form 3, dangerous waste permit application documentation have been submitted.

Tri-Party Agreement Milestone M-20-16 was satisfied with the submittal of the Part B dangerous waste permit application documentation to Ecology and the EPA in June 1991. The first Notice of Deficiency was received from Ecology on March 24, 1993. A Notice of Deficiency response table was prepared and submitted to Ecology and the EPA on July 13, 1993. A second set of Notice of Deficiency comments was received from Ecology on February 8, 1994. Workshops are ongoing with Ecology to finalize Revision 1 of the Double-Shell Tank System Part B Dangerous Waste Permit Application documentation. The Double-Shell Tank System is scheduled to be incorporated into the HF RCRA Permit (DW Portion) in Modification E, calendar year 1999.

Compiled by: Waste Management Federal Services of Hanford, Inc. for Fluor Daniel Hanford, Inc. 
DOE Operations Office: Richland

DOE Facility: Hanford Site

Existing Permit ( ) $\quad$ Renewal ( ) New Permit (X)

Permit Type: RCRA

Permitting Agency: Washington State Department of Ecology

Permit Number: WA7890008967

Permitted Unit: Grout Treatment Facility

Issuance Date:

Expiration Date:

Need for Headquarters' Action

(for permit renewals or new permits)
Yes ( ) No (X)

If yes, HQ Program Element

Brief Summary of Relevant Information (major permit conditions, status of compliance or unusual problems):

Part A, Form 3, dangerous waste permit application documentation for the Grout Treatment Facility originally was submitted to Ecology and the EPA in September 1987. Five revisions of the Part A, Form 3, dangerous waste permit application documentation have been submitted.

Part B dangerous waste permit application documentation originally was submitted to Ecology and the EPA on November 23, 1988. Per the Fourth Amendment of the Tri-Party Agreement, the Grout Treatment Facility has been placed in a standby mode. A letter notifying Ecology and the EPA that all work on the Grout Treatment Facility Part B dangerous waste permit application documentation was discontinued was submitted on April 26, 1994.

Compiled by: Waste Management Federal Services of Hanford, Inc., Date: July 31, 1997 for Fluor Daniel Hanford, Inc. 
DOE Operations Office: Richland

DOE Facility: Hanford Site

Existing Permit ( )

Renewal ( )

New Permit ( $\mathrm{X}$ )

Permit Type: RCRA

Permitting Agency: Washington State Department of Ecology

Permit Number: WA7890008967

Permitted Unit: Hanford Waste Vitrification Plant

Issuance Date:

Expiration Date:

Need for Headquarters' Action

(for permit renewals or new permits)
Yes ( ) No (X)

If yes, HQ Program Element

Brief Summary of Relevant Information (major permit conditions, status of compliance or unusual problems):

Part A, Form 3, dangerous waste permit application documentation for the Hanford Waste Vitrification Plant originally was submitted to Ecology and the EPA in May 1988. Five revisions of the Part A, Form 3, dangerous waste permit application documentation have been submitted.

Per Amendment Four of the Tri-Party Agreement, construction of a high-level waste vitrification plant, such as the Hanford Waste Vitrification Plant, was delayed until 2002 to accommodate changes in waste management planning and prioritization. Hot startup of a high-level waste vitrification plant has been delayed until 2009 (per Tri-Party Agreement Milestone M-5I-03).

Compiled by: Waste Management Federal Services of Hanford, Inc.

Date: July 31, 1997 for Fluor Daniel Hanford, Inc. 
DOE Operations Office: Richland

DOE Facility: Hanford Site

Existing Permit ( ) Renewal ( ) New Permit (X)

Permit Type: RCRA

Permitting Agency: Washington State Department of Ecology

Permit Number: WA7890008967

Permitted Unit: Liquid Effluent Retention Facility

Issuance Date:

Expiration Date:

Need for Headquarters' Action

(for permit renewals or new permits)
Yes ( ) No ( $\mathrm{X}$ )

If yes, HQ Program Element

Brief Summary of Relevant Information (major permit conditions, status of compliance or unusual problems):

Part A, Form 3, dangerous waste permit application documentation for the Liquid Effluent Retention Facility (LERF) originally was submitted to Ecology and the EPA in February 1990. Five revisions of the Part A, Form 3, dangerous waste permit application documentation have been submitted.

Tri-Party Agreement Milestone M-20-47 was satisfied with the submittal of the Part B dangerous waste permit application documentation to Ecology and the EPA in June 1991. Subsequently, the LERF and 200 Area Effluent Treatment Facility (ETF) Part B dangerous waste permit applications have been combined into one Part B permit application, Revision O. The LERF/ETF permit application is scheduled for incorporation into the HF RCRA Permit (DW Portion) in Modification C, December 1997.

Compiled by: Waste Management Federal Services of Hanford, Inc.

Date: July 31, 1997 for Fluor Daniel Hanford, Inc. 
DOE Operations Office: Richland

DOE Facility: Hanford Site

Existing Permit ( )

Renewal ( )

New Permit ( $X$ )

Permit Type: RCRA

Permitting Agency: Washington State Department of Ecology

Permit Number: WA7890008967

Permitted Unit: Low-Level Burial Grounds

Issuance Date:

Expiration Date:

Need for Headquarters' Action

(for permit renewals or new permits)

Yes ( ) No (X)

If yes, HQ Program Element

Brief Summary of Relevant Information (major permit conditions, status of compliance or unusual problems):

Part A, Form 3, for the Low-Level Burial Grounds originally was submitted to Ecology and the EPA in October 1985. Ten revisions of the Part A, Form 3, dangerous waste permit application documentation have been submitted.

Tri-Party Agreement Milestone M-20-06 was satisfied with the submittal of the Part B dangerous waste permit application documentation to Ecology and the EPA in December 1989. The Low-Level Burial Grounds permit application is scheduled for incorporation into the HF RCRA Permit (DW Portion) in Modification C, December 1997.

Compiled by: Waste Management Federal Services of Hanford, Inc.

Date: July 31, 1997 for Fluor Daniel Hanford, Inc. 
DOE Operations Office: Richland

DOE Facility: Hanford Site

Existing Permit ( ) Renewal ( ) New Permit (X)

Permit Type: RCRA

Permitting Agency: Washington State Department of Ecology

Permit Number: WA7890008967

Permitted Unit: PUREX Storage Tunnels

Issuance Date:

Expiration Date:

Need for Headquarters' Action

(for permit renewals or new permits)
Yes ( ) No (X)

If yes, HQ Program Element

Brief Summary of Relevant Information (major permit conditions, status of compliance or unusual problems):

Part A, Form 3, dangerous waste permit application documentation for the PUREX Storage Tunnels originally was submitted to Ecology and the EPA in November 1987. Five revisions of the Part A, Form 3, dangerous waste permit application documentation have been submitted. The PUREX Storage Tunnels store material from the PUREX Plant and other sources.

Tri-Party Agreement Milestone M-20-11 was satisfied with the submittal of the Part B dangerous waste permit application documentation to Ecology and the EPA in September 1990. Revision 3 of the PUREX Storage Tunnels Part B dangerous waste permit application documentation was submitted to Ecology on July 26, 1996. The PUREX Storage Tunnels were incorporated into Revision 3 of the HF RCRA Permit (DW Portion) that became effective in December 1996. Revision 4 of the PUREX Storage Tunnels Part B dangerous waste permit application documentation was submitted to Ecology on April 14, 1997, and identifies Fluor Daniel Hanford, Inc., as the new cooperator. This submittal was performed at the request of Ecology and was considered a Class I Modification.

Compiled by: Waste Management Federal Services of Hanford, Inc.

Date: July 31, 1997 for Fluor Daniel Hanford, Inc. 
DOE Operations Office: Richland

DOE Facility: Hanford Site

Existing Permit ( ) Renewal ( ) New Permit (X)

Permit Type: RCRA

Permitting Agency: Washington State Department of Ecology

Permit Number: WA7890008967

Permitted Unit: Sodium Storage Facility and Sodium Reaction Facility

Issuance Date:

Expiration Date:

Need for Headquarters' Action

(for permit renewals or new permits)
Yes ( ) No (X)

If yes, HQ Program Element

Brief Summary of Relevant Information (major permit conditions, status of compliance or unusual problems):

Part A, Form 3, dangerous waste permit application documentation for the Sodium Storage Facility and Sodium Reaction Facility originally was submitted to Ecology and the EPA on May 1, 1995. One revision of the Part A, Form 3, dangerous waste permit application documentation has been submitted.

Shutdown of the Fast Flux Test Facility began in 1993. A study to determine if the sodium removed from the Fast Flux Test Facility has any beneficial use is to be completed in 1998. In the event that a beneficial use cannot be found, the Sodium Storage Facility and Sodium Reaction Facility will be relied on to process the sodium for disposal. The unit is being designed and constructed as a RCRAcompliant unit, in the event that the Fast Flux Test Facility sodium is determined to be a waste. Construction of the Sodium Storage Facility under interim status began in June 1995.

Compiled by: Waste Management Federal Services of Hanford, Inc.

Date: July 31, 1997 for Fluor Daniel Hanford, Inc. 
DOE Operations Office: Richland

DOE Facility: Hanford Sițe

Existing Permit ( ) Renewal ( ) New Permit (X)

Permit Type: RCRA

Permitting Agency: Washington State Department of Ecology

Permit Number: WA7890008967

Permitted Unit: T Plant Complex

Issuance Date:

Expiration Date:

Need for Headquarters' Action

(for permit renewals or new permits)
Ýes ( ) No (X)

If yes, HQ Program Element

Brief Summary of Relevant Information (major permit conditions, status of compliance or unusual problems):

Part A, Form 3, dangerous waste permit application documentation for the T Plant Complex originally was submitted to Ecology and the EPA in November 1987. Six revisions of the Part A, Form 3, dangerous waste permit application documentation have been submitted.

Tri-Party Agreement Milestone M-20-51 was satisfied with the submittal of the Part B dangerous waste permit application documentation to Ecology and the EPA in December 1995. The T Plant Complex is scheduled to be incorporated into the HF RCRA Permit (DW Portion) in Modification G, calendar year 2001.

Compiled by: Waste Management Federal Services of Hanford, Inc. for Fluor Daniel Hanford, Inc. 
DOE Operations Office: Richland

DOE Facility: Hanford Site

Existing Permit ( ) Renewal ( ) New Permit (X)

Permit Type: RCRA

Permitting Agency: Washington State Department of Ecology

Permit Number: WA7890008967

Permitted Unit: Waste Receiving and Processing Facility

Issuance Date:

Expiration Date:

Need for Headquarters' Action

(for permit renewals or new permits)
Yes ( ) No (X)

If yes, HQ Program Element

Brief Summary of Relevant Information (major permit conditions, status of compliance or unusual problems):

Part A, Form 3, dangerous waste permit application documentation for Waste Receiving and Processing Facility (WRAP) originally was submitted to Ecology and the EPA on January 25, 1995. One revision of the. Part A, Form 3, dangerous waste permit application documentation has been submitted.

Tri-Party Agreement Milestone M-20-12 was satisfied with the submittal of the Part B dangerous waste permit application documentation to Ecology and the EPA in October 1991. WRAP is scheduled to be incorporated into the HF RCRA Permit (DW Portion) in Modification D, calendar year 1998 .

Compiled by: Waste Management Federal Services of Hanford, Inc.

Date: July 31, 1997 for Fluor Daniel Hanford, Inc. 
This page intentionally left blank. 
RESOURCE CONSERVATION AND RECOVERY ACT WITHDRAWAL REQUESTS AND PROCEDURAL CLOSURES 
This page intentionally left blank. 
DOE Operations Office: Richland

DOE Facility: Hanford Site

Existing Permit ( ) Renewal ( ) New Permit (X)

Permit Type: RCRA Procedural Closure

Permitting Agency: Washington State Department of Ecology

Permit Number: WA7890008967

Permitted Unit: 221-T Containment Systems Test Facility

Issuance Date:

Expiration Date:

Need for Headquarters' Action

(for permit renewals or new permits)
Yes ( ) No (X)

If yes, HQ Program Element

Brief Summary of Relevant Information (major permit conditions, status of compliance or unusual problems):

Part A, Form 3, and Part B dangerous waste permit application documentation for the 221-T Containment Systems Test Facility originally was submitted to Ecology and the EPA in November 1985. Three revisions of the Part A, Form 3, dangerous waste permit application documentation have been submitted.

This unit was included in the withdrawal request package submitted to Ecology and the EPA on June 22, 1989, in fulfillment of Tri-Party Agreement Milestone M-20-45. Ecology reviewed this submittal and requested additional information for this unit. In December 1989, additional information was submitted to Ecology in support of the withdrawal request. In subsequent meetings with Ecology, Ecology requested additional information, which is being collected for transmittal. Closure is being actively pursued.

Compiled by: Waste Management Federal Services of Hanford, Inc. Date: July 31, 1997. for Fluor Daniel Hanford, Inc. 
DOE Operations Office: Richland

DOE Facility: Hanford Site

Existing Permit ( ) Renewal ( ) New Permit (X)

Permit Type: RCRA Procedural Closure

Permitting Agency: Washington State Department of Ecology

Permit Number: WA7890008967

Permitted Unit: 324 Pilot Plant

Issuance Date:

Expiration Date:

Need for Headquarters' Action

(for permit renewals or new permits)
Yes ( ) No (X)

If yes, HQ Program Element

Brief Summary of Relevant Information (major permit conditions, status of compliance or unusual problems):

Part A, Form 3, dangerous waste permit application documentation for the 324 Pilot Plant originally was submitted to Ecology and the EPA in November 1985. Three revisions of the Part A, Form 3, dangerous waste permit application documentation have been submitted.

This unit was included in the withdrawal request package submitted to Ecology and the EPA on June 22, 1989, in fulfillment of Tri-Party Agreement Milestone M-20-45. Ecology reviewed this submittal and requested additional information for this unit. In December .1989, additional information was submitted to Ecology in support of the withdrawal request. On August 8, 1996, Ecology inspected the 324 Pilot Plant and requested information necessary to support procedural closure. This information was provided to Ecology in three submittals dated August 12, September 5, and November 1, 1996. On February 20, 1997, Ecology notified DOE-RL that the documentation was complete. Subsequently, Ecology completed the administrative process. The Part A, Form 3, dangerous waste permit application documentation was stamped with "closed $06 / 09 / 97 "$ to indicate that procedural closure occurred.

Compiled by: Pacific Northwest National Laboratory

Date: July 31, 1997

Environmental Protection 
DOE Operations Office: Richland

DOE Facility: Hanford Site

Existing Permit ( ) Renewal ( ) New Permit (X)

Permit Type: RCRA Procedural Closure

Permitting Agency: Washington State Department of Ecology

Permit Number: WA7890008967

Permitted Unit: 332 Storage Facility

Issuance Date:

Expiration Date:

Need for Headquarters' Action

(for permit renewals or new permits)
Yes ( ) No (X)

If yes, HQ Program Element

Brief Summary of Relevant Information (major permit conditions, status of compliance or unusual problems):

Part A, Form 3, dangerous waste permit application documentation for the 332 Storage Facility originally was submitted to Ecology and the EPA in May 1988. No revisions of the Part A, Form 3, dangerous waste permit application documentation have been submitted.

This unit was included in the withdrawal request package submitted to Ecology and the EPA on June 22, 1989, in fulfillment of Tri-Party Agreement Milestone M-20-45. Ecology reviewed this submittal and requested additional information for this unit. In December 1989, additional information was submitted to Ecology in support of the withdrawal request. On August 8, 1996, Ecology inspected the 332 Storage Facility and requested information necessary to support procedural closure. This information was provided to Ecology in three submittals dated August 12, September 5, and November 14, 1996. Subsequently, Ecology completed the administrative process. The Part A, Form 3, dangerous waste permit application documentation was stamped with "closed $04 / 21 / 97^{\prime \prime}$ to indicate that procedural closure occurred.

Compiled by: Pacific Northwest National Laboratory

Date: July 31, 1997 Environmental Protection 
DOE Operations Office: Richland

DOE Facility: Hanford Site

Existing Permit ( ) Renewal ( ) New Permit (X)

Permit Type: RCRA Procedural Closure

Permitting Agency: Washington State Department of Ecology

Permit Number: WA7890008967

Permitted Unit: 437 Maintenance and Storage Facility

Issuance Date:

Expiration Date:

Need for Headquarters' Action

(for permit renewals or new permits)
Yes ( ) No (X)

If yes, HQ Program Element

Brief Summary of Relevant Information (major permit conditions, status of compliance or unusual problems):

Part A, Form 3, and Part B dangerous waste permit application documentation for the Maintenance and Storage Facility originally was submitted to Ecology and the EPA in November 1985. Three revisions of the Part A, Form 3, dangerous waste permit application documentation have been submitted.

Tri-Party Agreement Milestone M-20-29 required submittal of revised Part B dangerous waste permit application documentation to Ecology and the EPA by November 30, 1993. Tri-Party Agreement change request M-20-92-6 was submitted to Ecology and the EPA in September 1992, which deferred the milestone. Regulator approval of the change request was received in October 1992. The decision to shutdown the Fast Flux Test Facility was made in 1994. Procedural closure, in accordance with Section 6.3.3 of the Tri-Party Agreement, has been halted while FFTF undergoes evaluation for startup for tritium production.

Compiled by: Waste Management Federal Services of Hanford, Inc.

Date: July 31, 1997 for Fluor Daniel Hanford, Inc. 
DOE Operations Office: Richland

DOE Facility: Hanford Site

Existing Permit ( ) Renewal ( ) New Permit (X)

Permit Type: RCRA Procedural Closure

Permitting Agency: Washington State Department of Ecology

Permit Number: WA7890008967

Permitted Unit: 1706-KE Waste Treatment System

Issuance Date:

Expiration Date:

Need for Headquarters' Action

(for permit renewals or new permits)
Yes ( ) No (X)

If yes, HQ Program Element

Brief Summary of Relevant Information (major permit conditions, status of compliance or unusual problems):

Part A, Form 3, dangerous waste permit application documentation for the 1706-KE Waste Treatment System originally was submitted to Ecology in August 1986. Three revisions of the Part A, Form 3, dangerous waste permit application documentation have been submitted. Part B dangerous waste permit application documentation was submitted to Ecology and the EPA in April 1987.

This unit was included in the withdrawal request package submitted to Ecology and the EPA on June 22, 1989, in fulfillment of Tri-Party Agreement Milestone M-20-45. Ecology reviewed this submittal and requested additional information for this unit. In December 1989, additional information was submitted to Ecology in support of the withdrawal request. Ecology has requested additional information which is being collected for transmittal.

Compiled by: Waste Management Federal Services of Hanford, Inc.

Date: July 31, 1997 for Fluor Daniel Hanford, Inc. 
DOE Operations Office: Richland

DOE Facility: Hanford Site

Existing Permit ( ) Renewal ( ) New Permit (X)

Permit Type: RCRA Procedural Closure

Permitting Agency: Washington State Department of Ecology

Permit Number: WA7890008967

Permitted Unit: $2727-W A$ Sodium Reactor Experiment Sodium Storage Building

Issuance Date:

Expiration Date:

Need for Headquarters' Action

(for permit renewals or new permits)
Yes ( ) No (X)

If yes, HQ Program Element

Brief Summary of Relevant Information (major permit conditions, status of compliance or unusual problems):

Part A, Form 3, dangerous waste permit application documentation for the 2727-WA Sodium Reactor Experiment Sodium Storage Building originally was submitted to Ecology and the EPA in November 1987. One revision of the Part A, Form 3, dangerous waste permit application documentation has been submitted.

This unit was included in the withdrawal request package submitted to Ecology and the EPA on June 22, 1989, in fulfillment of Tri-Party Agreement Milestore M-20-45. Ecology reviewed this submittal and requested additional information for this unit. In December 1989, additional information was submitted to Ecology in support of the withdrawal request. Ecology is scheduled to proceed on this withdrawal request closure early in calendar year 1998.

Compiled by: Waste Management Federal Services of Hanford, Inc.

Date: July 31, 1997

for Fluor Daniel Hanford, Inc. 
DOE Operations Office: Richland

DOE Facility: Hanford Site

Existing Permit ( ) Renewal ( ) New Permit (X)

Permit Type: RCRA Procedural Closure

Permitting Agency: Washington State Department of Ecology

Permit Number: WA7890008967

Permitted Unit: Biological Treatment Test Facilities

Issuance Date:

Expiration Date:

Need for Headquarters' Action

(for permit renewals or new permits)
Yes ( ) No (X)

If yes, HQ Program Element

Brief Summary of Relevant Information (major permit conditions, status of compliance or unusual problems):

Part A, Form 3, dangerous waste permit application documentation for the Biological Treatment Test Facilities originally was submitted to Ecology and the EPA in May 1988. No revisions of the Part A, Form 3, dangerous waste permit application documentation have been submitted.

Procedural closure documentation, in accordance with Section 6.3.3 of the Tri-Party Agreement, was submitted in December 1995 to fulfill Milestone M-20-44. On July 1.I, I996, Ecology notified DOE-RL that the documentation was complete. On December 10, 1996, Ecology completed the administrative process. The Part A, Form 3, dangerous waste permit application documentation was stamped with "closed 12/10/96" to indicate that procedural closure occurred.

Compiled by: Pacific Northwest National Laboratory Environmental Protection

Date: July 31,1997 
DOE Operations Office: Richland

DOE Facility: Hanford Site

Existing Permit ( ) Renewal ( ) New Permit (X)

Permit Type: RCRA Procedural Closure

Permitting Agency: Washington State Department of Ecology

Permit Number: WA7890008967

Permitted Unit: Physical and Chemical Treatment Test Facilities

Issuance Date:

Expiration Date:

Need for Headquarters' Action

(for permit renewals or new permits)
Yes ( ) No (X)

If yes, HQ Program Element

Brief Summary of Relevant Information (major permit conditions, status of compliance or unusual problems):

Part A, Form 3, dangerous waste permit application documentation for the Physical and Chemical Treatment Test Facilities originally was submitted to Ecology and the EPA in May 1988. One revision of the Part A, Form 3, dangerous waste permit application documentation has been submitted.

Procedural closure documentation, in accordance with Section 6.3.3 of the Tri-Party Agreement, was submitted in September 1995 to fulfill Milestone M-20-43A. On January 25, 1996, Ecology notified DOE-RL that the administrative process was complete. The Part A, Form 3, dangerous waste permit application documentation was stamped with "closed as of $05 / 13 / 96$ " to indicate that procedural closure occurred.

Compiled by: Pacific Northwest National Laboratory

Date: July 31, 1997

Environmental Protection 
DOE Operations Office: Richland

DOE Facility: Hanford Site

Existing Permit ( ) Renewal ( ) New Permit (X)

Permit Type: RCRA Procedural Closure

Permitting Agency: Washington State Department of Ecology

Permit Number: WA7890008967

Permitted Unit: Thermal Treatment Test Facilities

Issuance Date:

Expiration Date:

Need for Headquarters' Action

(for permit renewals or new permits)
Yes ( ) No (X)

If yes, HQ Program Element

Brief Summary of Relevant Information (major permit conditions, status of compliance or unusual problems):

Part A, Form 3, dangerous waste permit application documentation for the Thermal Treatment Test Facilities originally was submitted to Ecology and the EPA in May 1988. No revisions of the Part A, Form 3, dangerous waste permit application documentation have been submitted.

Procedural closure documentation, in accordance with Section 6.3.3 of the Tri-Party Agreement, was submitted in September 1995 to fulfill Milestone M-20-42A. On January 25, 1996, Ecology notified DOE-RL that the administrative process was complete. The Part A, Form 3, dangerous waste permit application documentation was stamped with "closed as of $05 / 13 / 96$ " to indicate that procedural closure occurred.

Compiled by: . Pacific Northwest National Laboratory Environmental Protection

Date: July 31, 1997 
This page intentionally left blank. 
RESOURCE CONSERVATION AND RECOVERY ACT RESEARCH, DEVELOPMENT, AND DEMONSTRATION PERMITTING 
This page intentionally left blank. 
DOE Operations Office: Richland

DOE Facility: Hanford Site

Existing Permit (X) Renewal ( ) New Permit ( )

Permit Type: RCRA

Permitting Agency: U.S. Environmental Protection Agency, Region 10 Washington State Department of Ecology

Permit Number: WA7890008967

Permitted Unit: Waste Water Pilot Plant

Issuance Date: May 4, 1994

Expiration Date: June 6, 1998

Need for Headquarters' Action Yes ( ) No ( $\mathrm{X}$ )

(for permit renewals or new permits) If yes, HQ Program Element

Brief Summary of Relevant Information (major permit conditions, status of compliance or unusual problems):

Revision 1 of RD\&D permit application documentation for the Waste Water Pilot Plant was submitted to Ecology and the EPA in April 1992. Revision 0 of the Waste Water Pilot Plant RD\&D Permit was issued on May 4, 1994, and became effective on June 6, 1994.

Work under the RD\&D permit was completed in 1995. On April 21, 1997, a letter was submitted to Ecology initiating closure activities for the Waste Water Pilot Plant permitted areas.

Compiled by: Waste Management Federal Services of Hanford, Inc. for Fluor Daniel Hanford, Inc.

Date: July 31, 1997 
DOE/RL-96-63, Rev. 1

$10 / 97$

This page intentionally left blank. 


\section{TOXIC SUBSTANCES CONTROL ACT PERMITTING}


DOE/RL-96-63, Rev. 1

$10 / 97$

This page intentionally left blank. 
DOE Operations Office: Richland

DOE Facility: Hanford Site

Existing Permit ( )

Renewal ( )

New Permit ( $\mathrm{X}$ )

Permit Type: TSCA

Permitting Agency: U.S. Environmental Protection Agency, Region 10

Permit Number:

Permitted Unit: Low-Level Burial Grounds

Issuance Date:

Expiration Date:

Need for Headquarters' Action

(for permit renewals or new permits)
Yes ( ) No (X)

If yes, HQ Program Element

Brief Summary of Relevant Information (major permit conditions, status of compliance or unusual problems):

Revision 2 of the Request for Interim Approval to Operate Trench 94 of the 218-E-12B Burial Ground as a Chemical Waste Landfill for Disposal of Polychlorinated Biphenyl Waste in Submarine Reactor Compartments was submitted to the EPA on June 10. 1994. This revision sought interim approval to operate a Toxic Substances Control Act chemical waste landfill for the disposal of polychlorinated biphenyl waste.

The EPA tentatively approved the chemical waste landfill request pending issuance of the Low-Level Burial Grounds Part B dangerous waste permit application documentation. The EPA determined that DOE-RL's documentation of compliance with WAC 173-303, which is equivalent to or more stringent than Toxic Substances Control Act chemical requirements, would be sufficient to show compliance with the Toxic Substances Control Act requirements. The Low-Level Burial Ground permit application is scheduled for incorporation into the HF RCRA Permit (DW Portion) in Modification C, December 1997.

Compiled by: Waste Management Federal Services of Hanford, Inc. for Fluor Daniel Hanford, Inc.

Date: July 31, 1997 
DOE/RL-96-63, Rev. 1

This page intentionally left blank. 
DOE/RL-96-63, Rev. 1

$10 / 97$

\section{RESOURCE CONSERVATION AND RECOVERY ACT}

\section{CLOSURE PLANS}


This page intentionally left blank. 
DOE Operations Office: Richland

DOE Facility: Hanford Site

Existing Permit ( ) Renewal ( ) New Permit (X)

Permit Type: RCRA Closure Plan

Permitting Agency: Washington State Department of Ecology

Permit Number: WA7890008967

Permitted Unit: 100-D Ponds

Issuance Date:

Expiration Date:

Need for Headquarters' Action

(for permit renewals or new permits)
Yes ( ) No (X)

If yes, HQ Program Element

Brief Summary of Relevant Information (major permit conditions, status of compliance or unusual problems):

Part A, Form 3, dangerous waste permit application documentation for the 100-D Ponds originally was submitted to Ecology and the EPA in August 1986. Four revisions of the Part A, Form 3, dangerous waste permit application documentation have been submitted.

Tri-Party Agreement Milestone M-20-40 was satisfied with the submittal of the 100-D Ponds Closure Plan to Ecology and the EPA on February 26, 1993. This closure plan is under review by the regulators. The 100-D Ponds is scheduled to be incorporated into the HF RCRA Permit (DW Portion) in Modification D, calendar year 1998

Unit characterization was performed in January 1995. A data quality objectives process was carried out between December 1995 and January 1996. This process concluded that sampling was adequate to characterize the surface soils at the unit. Excavation of contaminated surface soils occurred in the last quarter of fiscal year 1996. Ecology has stated that soils at depth may require further sampling to determine if this unit can close under a clean closure option.

Compiled by: Bechtel Hanford, Inc.

Date: July 31, 1997

Regulatory Support 
DOE Operations Office: Richland

DOE Facility: Hanford Site

Existing Permit ( ) Renewal ( ) New Permit (X)

Permit Type: RCRA Closure Plan

Permitting Agency: Washington State Department of Ecology

Permit Number: WA7890008967

Permitted Unit: 105-DR Large Sodium Fire Facility

Issuance Date: September 28, 1995 (Date Revision 2 of the HFr RCRA Permit became effective, 30 days after permit issunace.)

Expiration Date: September 27, 2004

Need for Headquarters' Action

Yes ( ) No (X)

(for permit renewals or new permits)

If yes, HQ Program Element

Brief Summary of Relevant Information (major permit conditions, status of compliance or unusual problems):

Part A, Form 3, and Part B dangerous waste permit application documentation for the 105-DR Large Sodium Fire Facility originally was submitted to Ecology and the EPA in November 1985. Subsequently, a decision was made to close this TSD unit. Three revisions of the Part A, Form 3, dangerous waste permit application documentation have been submitted.

Tri-Party Agreement Milestone M-20-41 was satisfied with the submittal of the 105-DR Large Sodium Fire Facility Closure Plan to Ecology and the EPA in September 1990. Revision 2 of the closure plan was submitted to Ecology and the EPA in April 1995. The 105-DR Large Sodium Fire Facility Closure Plan was incorporated into Revision 2 of the HF RCRA Permit (DW Portion) that became effective on September 28, 1995.

Closure activities began in July 1995 and were completed in March 1996. Closure certification was submitted to Ecology on June 19, 1996, and Ecology accepted partial clean closure on July 16, 1996. The unit has been partially clean closed with the Part A. Form 3, revised to show the clean closed areas of the unit. The areas that were not cleaned closed will be remediated during decommissioning of the 105-DR reactor building and associated systems.

Compiled by: Waste Management Federal Services of Hanford, Inc.

Date: July 31, 1997

for Fluor Daniel Hanford, Inc. 
DOE Operations Office: Richland

DOE Facility: Hanford Site

Existing Permit (X) Renewal ( ) New Permit ( )

Permit Type: RCRA Closure Plan

Permitting Agency: Washington State Department of Ecology

Permit Number: WA7890008967

Permitted Unit: 200 West Area Ash Pit Demolition Site

Issuance Date: May 29, 1995 (Date Revision i of the HF RCRA Permit became effective. 30 days after permit issuance.)

Expiration Date: September 27, 2004

Need for Headquarters' Action

(for permit renewals or new permits)
Yes ( ) No (X)

If yes, HQ Program Element

Brief Summary of Relevant Information (major permit conditions, status of compliance or unusual problems):

. Part A, Form 3, and Part B dangerous waste permit application documentation for the 200 West Area Ash Pit Demolition Site originally was submitted to Ecology and the EPA in November 1985. Subsequently, a decision was made to close this TSD unit. Four revisions of the Part A, Form 3, dangerous waste permit application documentation have been submitted.

Tri-Party Agreement Milestone M-20-26 was satisfied with the submittal of the 200 West Area Ash Pit Demolition Site Closure Plan to Ecology and the EPA in November 1992. Revision 1 of the closure plan was submitted to Ecology and the EPA in October 1994. Revision 1 of the 200 West Area Ash Pit Demolition Site Closure Plan was incorporated into Revision I of the HF RCRA Permit (DW Portion) that became effective on May 29, 1995 . Closure certification was submitted to Ecology on September 22, 1995. On October 26, 1995, Ecology approved the clean closure certification. The Part A, Form 3, dangerous waste permit application documentation was stamped with "closed as of 10/26/95" and submitted to Ecology on November 28, 1995.

Compiled by: Waste Management Federal Services of Hanford, Inc.

Date: July 31, 1997 for Fluor Daniel Hanford, Inc. 
DOE Operations Office: Richland

DOE Facility: Hanford Site

Existing Permit $($ ) Renewal ( ) New Permit (X)

Permit Type: RCRA Closure Plan

Permitting Agency: Washington State Department of Ecology

U. S. Environmental Protection Agency, Region 10

Permit Number: WA7890008967

Permitted Unit: 207-A South Retention Basin

Issuance Date:

Expiration Date:

Need for Headquarters' Action

(for permit renewals or new permits)
Yes ( ) No (X)

If yes, HQ Program Element

Brief Summary of Relevant Information (major permit conditions, status of compliance or unusual problems):

Part A, Form 3, dangerous waste permit application documentation for the 207-A South Retention Basin originally was submitted to Ecology and the EPA in February 1990. Two revisions of the Part A, Form 3, dangerous waste permit application documentation have been submitted.

A Tri-Party Agreement change request was prepared to coordinate the 207-A South Retention Basin closure plan with the past-practice documentation for the 200-PO-5 Operable Unit. The submittal date for this documentation is October 31, 1999, to Ecology and the EPA.

Compiled by: Waste Management Federal Services of Hanford, Inc.

Date: July 31, 1997

for Fluor Daniel Hanford, Inc. 
DOE Operations Office: Richland

DOE Facility: Hanford Site

Existing Permit ( $\mathrm{X}$ ) Renewal ( ) New Permit ( )

Permit Type: RCRA Closure Plan

Permitting Agency: Washington State Department of Ecology

Permit Number: WA7.890008967

Permitted Unit: 216-B-3 Expansion Ponds

Issuance Date: May 29, 1995 (Date Revision 1 of the HF RCRA Pemmit became effective, 30 days atter permit issuance)

Expiration Date: September 27, 2004

Need for Headquarters' Action

(for permit renewals or new permits)

Yes ( ) No ( $\mathrm{X}$ )

If yes, HQ Program Element

Brief Summary of Relevant Information (major permit conditions, status of compliance or unusual problems):

Originally the 216-B-3 Expansion Ponds were included with the 216-B-3 Pond Main Lobe, in a single Part A, Form 3, dangerous waste permit application documentation. In December 1993, the 216-B-3 Pond System Part A, Form 3, dangerous waste permit application documentation was separated into two Part A, Form 3s: one for the 216-B-3 Expansion Ponds and one for the 216-B-3 Main Pond and 216-B-3-3 Ditch. Part A, Form 3, dangerous waste permit application and closure plan documentation for the 216-B-3 Expansion Ponds were submitted to Ecology and the EPA on December 16, 1993. No revisions of the Part A, Form 3, dangerous waste permit application documentation have been submitted.

Revision 2 of the 216-B-3 Expansion Ponds Closure Plan was incorporated into Revision 1 of the HF RCRA Permit (DW Portion) that became effective on May 29, 1995. Closure certification was submitted to Ecology on June 14, 1995. On June 27, 1995, Ecology approved the clean closure certification. The Part A, Form 3, dangerous waste permit application documentation was stamped with "closed as of 06/27/95" and submitted to Ecology on July 31, 1995.

Compiled by: Waste Management Federal Services of Hanford, Inc. Date: July 31, 1997 for Fluor Daniel Hanford, Inc. 
DOE Operations Office: Richland

DOE Facility: Hanford Site

Existing Permit ( ) Renewal ( ) New Permit (X)

Permit Type: RCRA Closure Plan

Permitting Agency: Washington State Department of Ecology

U.S. Environmental Protection Agency, Region 10

Permit Number: WA7890008967

Permitted Unit: $216-\mathrm{B}-63$ Trench

Issuance Date:

Expiration Date:

Need for Headquarters' Action

(for permit renewals or new permits)
Yes ( ) No (X)

If yes, HQ Program Element

Brief Summary of Relevant Information (major permit conditions, status of compliance or unusual problems):

Part A, Form 3, dangerous waste permit application documentation for the 216-B-63 Trench originally was submitted to Ecology and the EPA in August 1986. Three revisions of the Part A, Form 3, dangerous waste permit application documentation have been submitted.

The 216-B-63 Trench Closure Plan was submitted to Ecology and the EPA in April 1987. A Tri-Party Agreement change request was approved to coordinate the closure plan with the past-practice documentation for the 200-BP-11 Operable Unit. In March 1995, Draft B of the Work Plan for the 200-BP-11 Operable Unit was issued and incorporated the 216-B-63 Trench. This work plan integrates the TSD activities with the 200-BP-11 Operable Unit documentation and characterization. The 216-B-63 Trench is scheduled to be incorporated into the HF RCRA Permit (DW Portion) in Modification F, calendar year 2000.

Compiled by: Waste Management Federal Services of Hanford, Inc.

Date: July 31, 1997

for Fluor Daniel Hanford, Inc. 
DOE Operations Office: Richland

DOE Facility: Hanford Site

Existing Permit ( ) Renewal ( ) New Permit (X)

Permit Type: RCRA Closure Plan

Permitting Agency: Washington State Department of Ecology

U.S. Environmental Protection Agency, Region 10

Permit Number: WA7890008967

Permitted Unit: 216-S-10 Pond and Ditch

Issuance Date:

Expiration Date:

Need for Headquarters' Action

(for permit renewals or new permits)
Yes ( ) No ( $X)$

If yes, HQ Program Element

Brief Summary of Relevant Information (major permit conditions, status of compliance or unusual problems):

Part A, Form 3, dangerous waste permit application documentation for the 216-S-10 Pond and Ditch originally was submitted to Ecology and the EPA in February 1987. Three revisions of the Part A, Form 3, dangerous waste permit application documentation have been submitted.

The 216-S-10 Pond and Ditch Closure Plan was submitted to Ecology and the EPA in June 1987. Tri-Party Agreement Milestone M-20-39 requires submittal of an updated closure plan to Ecology by June 1999, coordinated with the past-practice documentation for the 200-RO-1 Operable Unit.

Compiled by: Bechtel Hanford, Inc.

Date: July 31, 1997

Regulatory Support 
DOE Operations Office: Richland,

DOE Facility: Hanford Site

Existing Permit (X) Renewal ( ) New Permit ( )

Permit Type: RCRA Closure Plan

Permitting Agency: Washington State Department of Ecology

Permit Number: WA7890008967

Permitted Unit: 218-E-8 Borrow Pit Demolition Site

Issuance Date: May 29, 1995 (Date Revision 1 of the HF RCRA Pemit became entective, 30 days after pemit issuance.)

Expiration Date: September 27, 2004

Need for Headquarters' Action

(for permit renewals or new permits)

Yes ( ) No (X)

If yes, HQ Program Element

Brief Summary of Relevant Information (major permit conditions, status of compliance or unusual problems):

Part A, Form 3, and Part B dangerous waste permit application documentation for the 218-E-8 Borrow Pit Demolition Site originally was submitted to Ecology and the EPA in November 1985. Subsequently, a decision was made to close this TSD unit. Four revisions of the Part A, Form 3, dangerous waste permit application documentation have been submitted.

Tri-Party Agreement Milestone M-20-28 was satisfied with the submittal of the 218-E-8 Borrow Pit Demolition Site Closure Plan to Ecology and the EPA in November 1992. Revision 1 of the closure plan was submitted to Ecology and the EPA in September 1994. Revision 1 of the 218-E-8 Borrow Pit Demolition Site Closure Plan was incorporated into Revision 1 of the HF RCRA Permit (DW Portion) that became effective on May 29, 1995. Closure certification was submitted to Ecology on September 22, 1995. On October 26, 1995. Ecology approved the clean closure certification. The Part A, Form 3, dangerous waste permit application documentation was stamped with "closed as of 10/26/95" and submitted to Ecology on November 28, 1995.

Compiled by: Waste Management Federal Services of Hanford, Inc. Date: July 31, 1997 for Fluor Daniel Hanford, Ine. 
DOE Operations Office: Richland

DOE Facility: Hanford Site

Existing Permit (X) Renewal ( ) New Permit ( )

Permit Type: RCRA Closure Plan

Permitting Agency: Washington State Department of Ecology

Permit Number: WA7890008967

Permitted Unit: 300 Area Solvent Evaporator

Issuance Date: September 28, 1994 (Date Revision 0 of the HF RCRA Pemit became effictive, 30 days after pemit issuance.)

Expiration Date: September 27, 2004

Need for Headquarters' Action

(for permit renewals or new permits)
Yes ( ) No (X)

If yes, HQ Program Element

Brief Summary of Relevant Information (major permit conditions, status of compliance or unusual problems):

Part A, Form 3, dangerous waste permit application documentation for the 300 Area Solvent Evaporator originally was submitted to Ecology and the EPA in November 1985. Four revisions of the Part A, Form 3, dangerous waste permit application documentation have been submitted.

The 300 Area Solvent Evaporator Closure Plan was submitted to Ecology and the EPA in February 1989. Revision 3B of the 300 Area Solvent Evaporator Closure Plan was incorporated into Revision 0 of the HF RCRA Permit (DW Portion) that became effective on September 28, 1994. Closure certification was submitted to Ecology on May 25, 1995. On June 27, 1995, Ecology approved the clean closure certification. The Part A, Form 3, dangerous waste permit application documentation was stamped with "closed as of 06/27/95" and submitted to Ecology on July 31, 1995.

Compiled by: Waste Management Federal Services of Hanford, Inc.

Date: July 31, 1997 for Fluor Daniel Hanford, Inc. 
DOE Operations Office: Richland

DOE Facility: Hanford Site

Existing Permit ( ) Renewal ( ) N New Permit (X)

Permit Type: RCRA Closure Plan

Permitting Agency: Washington State Department of Ecology

Permit Number: WA7890008967

Permitted Unit: 300 Area Waste Acid Treatment System

Issuance Date:

Expiration Date:

Need for Headquarters' Action

(for permit renewals or new permits)
Yes ( ) No (X)

If yes, HQ Program Element

Brief Summary of Relevant Information (major permit conditions, status of compliance or unusual problems):

Part A, Form 3, dangerous waste permit application documentation for the 300 Area Waste Acid Treatment System originally was submitted to Ecology and the EPA in September 1987. Four revisions of the Part A, Form 3, dangerous waste permit application documentation have been submitted.

Tri-Party Agreement Milestone M-20-10 was satisfied with the submittal of the 300 Area Waste Acid Treatment System Closure Plan to Ecology and the EPA in June 1990. Revision 1 of the closure plan was submitted to the regulators on April 9, 1996. The 300 Area Waste Acid Treatment System is scheduled to be incorporated into the HF RCRA Permit (DW Portion) in Modification D, December 1998.

Compiled by: Waste Management Federal Services of Hanford, Inc.

Date: July 31, 1997 for Fluor Daniel Hanford, Inc. 
DOE Operations Office: Richland

DOE Facility: Hanford Site

Existing Permit ( ) Renewal ( ) New Permit (X)

Permit Type: RCRA Closure Plan

Permitting Agency: Washington State Department of Ecology

Permit Number: WA7890008967

Permitted Unit: 303-K Storage Facility

Issuance Date:

Expiration Date:

Need for Headquarters' Action

(for permit renewals or new permits)
Yes ( ) No (X)

If yes, HQ Program Element

Brief Summary of Relevant Information (major permit conditions, status of compliance or unusual problems):

Part A, Form 3, dangerous waste permit application documentation for the 303-K Storage Facility originally was submitted to Ecology and the EPA in August 1987. Five revisions of the Part A, Form 3, dangerous waste permit application documentation have been submitted.

Tri-Party Agreement Milestone M-20-13 was satisfied with the submittal of the 303-K Storage Facility Closure Plan to Ecology and the EPA in April 1990. Revision 2A of the closure plan was submitted in July 1995. The 303-K Storage Facility was incorporated into Revision 3 of the HF RCRA Permit (DW Portion), effective December 1996. Closure activities are expected to begin in October 1997.

Compiled by: Waste Management Federal Services of Hanford, Inc.

Date: July 31, 1997 for Fluor Daniel Hanford, Inc. 
DOE Operations Office: Richland

DOE Facility: Hanford Site

Existing Permit ( )

Renewal ( )

New Permit ( $X)$

Permit Type: RCRA

Permitting Agency: Washington State Department of Ecology

U.S. Environmental Protection Agency, Region 10

Permit Number: WA7890008967

Permitted Unit: 303-M Oxide Facility

Issuance Date:

Expiration Date:

Need for Headquarters' Action

(for permit renewals or new permits)
Yes ( ) No (X)

If yes, HQ Program Element

Brief Summary of Relevant Information (major permit conditions, status of compliance or unusual problems):

Part A, Form 3, dangerous waste permit application documentation for the 303-M Oxide Facility originally was submitted to Ecology and the EPA in May 1988. One revision of the Part A, Form 3, dangerous waste permit application documentation has been submitted.

Tri-Party Agreement Milestone M-20-30 required submittal of the Part B dangerous waste permit application documentation to Ecology and the EPA by October 1992. A Tri-Party Agreement Change Request (M-20-92-05) was submitted to Ecology and the EPA to delete the existing milestone for submittal of the Part B dangerous waste permit application documentation in October 1992. The Tri-Party Agreement Change Request was approved on December 15, 1993, to integrate this unit with the 300-FF-2 Operable Unit Work Plan.

Compiled by: Waste Management Federal Services of Hanford, Inc.

Date: July 31, 1997 for Fluor Daniel Hanford, Inc. 
DOE Operations Office: Richland

DOE Facility: Hanford Site

Existing Permit $(X)$

Renewal ( )

New Permit ( )

Permit Type: RCRA Closure Plan

Permitting Agency: Washington State Department of Ecology

Permit Number: WA7890008967

Permitted Unit: 304 Concretion Facility

Issuance Date: September 28, 1995 (Date Revision 2 of the HF RCRA Permit became effective. 30 days after pemit issuence.)

Expiration Date: September 27, 2004

Need for Headquarters' Action

(for permit renewals or new permits)
Yes ( ) No (X)

If yes, HQ Program Element

Brief Summary of Relevant Information (major permit conditions, status of compliance or unusual problems):

Part A, Form 3, dangerous waste permit application documentation for the 304 Concretion Facility originaliy was submitted to Ecology and the EPA in August 1986. Four revisions of the Part A. Form 3, dangerous waste permit application documentation have been submitted.

Tri-Party Agreement Milestone M-20-15 was satisfied with the submittal of the 304 Concretion Facility Closure Plan to Ecology and the EPA in April 1990. Revision 2A of the 304 Concretion Facility Closure Plan was incorporated into Revision 2 of the HF RCRA Permit (DW Portion) that became effective on September 28, 1995. Closure certification was submitted to Ecology on October 27, 1995. On November 30, 1995, Ecology approved the clean closure certification. The Part A, Form 3, dangerous waste permit application documentation was stamped with "closed as of 11/30/95" and submitted to Ecology on January 21, 1996.

Compiled by: Waste Management Federal Services of Hanford, Inc.

Date: July 31, 1997 for Fluor Daniel Hanford, Inc. 
DOE Operations Office: Richland

DOE Facility: Hanford Site

Existing Permit ( ) Renewal ( ) New Permit (X)

Permit Type: RCRA Closure Plan

Permitting Agency: Washington State Department of Ecology

U.S. Environmental Protection Agency, Region 10

Permit Number: WA7890008967

Permitted Unit: 1324-N Surface Impoundment

Issuance Date:

Expiration Date:

Need for Headquarters' Action

(for permit renewals or new permits)
Yes ( ) No ( $\mathrm{X}$ )

If yes, HQ Program Element

Brief Summary of Relevant Information (major permit conditions, status of compliance or unusual problems):

Part A, Form 3, dangerous waste permit application documentation for the 1324-N Surface Impoundment originally was submitted to Ecology and the EPA in August 1986. Three revisions of the Part A, Form 3, dangerous waste permit application documentation have been submitted.

This TSD unit will be included in the 1324-N Surface Impoundment and 1324-NA Percolation Pond Closure Plan. Tri-Party Agreement Milestone M-20-35 required submittal of an updated 1324-N Surface Impoundment and 1324-NA Percolation Pond Closure and Postclosure Plan to Ecology and the EPA by September 30, 1994. Tri-Party Agreement change request M-20-94-01 was approved on May 20, 1994, changing the submittal date of an updated closure and postclosure plan to a "to be determined". This unit will be included as an attachment to the corrective measures study for the 100-N Area TSD units. The 1324-N Surface Impoundment is scheduled to be incorporated into the HF RCRA Permit (DW Portion) in Modification D, calendar year 1998.

Compiled by: Bechtel Hanford, Inc.

Date: July 31, 1997

Regulatory Support 
DOE Operations Office: Richland

DOE Facility: Hanford Site

Existing Permit ( ) Renewal ( ) New Permit (X)

Permit Type: RCRA Closure Plan

Permitting Agency: Washington State Department of Ecology

U.S. Environmental Protection Agency, Region 10

Permit Number: WA7890008967

Permitted Unit: 1324-NA Percolation Pond

Issuance Date:

Expiration Date:

Need for Headquarters' Action

(for permit renewals or new permits)
Yes ( ) No (X)

If yes, HQ Program Element

Brief Summary of Relevant Information (major permit conditions, status of compliance or unusual problems):

Part A, Form 3, dangerous waste permit application documentation for the 1324-NA Percolation Pond originally was submitted to Ecology and the EPA in August 1986. Three revisions of the Part A, Form 3, dangerous waste permit application documentation have been submitted.

The 1324-NA Percolation Pond Closure Plan originally was submitted to Ecology and the EPA in April 1987. This TSD unit will be included in the 1324-N Surface Impoundment and 1324-NA Percolation Pond Closure Plan. Tri-Party Agreement Milestone M-20-35 required submittal of an updated 1324-N Surface Impoundment and 1324-NA Percolation Pond Closure and Postclosure Plan to Ecology and the EPA by September 30, 1994. Tri-Party Agreement change request M-20-94-01 was approved on May 20,1994, changing the submittal date of an updated closure and postclosure plan to a "to be determined." This unit will be included as an attachment to the corrective measures study for the 100-N Area TSD units. The 1324NA Percolation Pond is scheduled to be incorporated into the HF RCRA Permit (DW Portion) in Modification D, calendar year 1998.

Compiled by: Bechtel Hanford, Inc.

Date: July 31, 1997

Regulatory Support 
DOE Operations Office: Richland

DOE Facility: Hanford Site

Existing Permit (X) Renewal ( ) New Permit. ( )

Permit Type: RCRA Closure Plan

Permitting Agency: Washington State Department of Ecology

Permit Number: WA7890008967

Permitted Unit: 2101-M Pond

Issuance Date: May 29, 1995 (Date Revision 1 of the HF RCRA Permit became effective, 30 days after permit issuance.)

Expiration Date: September 27, 2004

Need for Headquarters' Action

(for permit renewals or new permits)
Yes ( ) No (X)

If yes, HQ Program Element

Brief Summary of Relevant Information (major permit conditions, status of compliance or unusual problems):

Part A, Form 3, dangerous waste permit application documentation for the 2101-M Pond originally was submitted to Ecology and the EPA in August 1986. Two revisions of the Part A, Form 3, dangerous waste permit application documentation have been submitted.

Tri-Party Agreement Milestone M-20-04 was satisfied with the submittal of the 2101-M Pond Closure Plan to Ecology and the EPA in September 1989. Revision 2 of the closure plan was submitted on June 30, 1993. Revision 2 of the 2101-M Pond Closure Plan was incorporated into Revision 1 of the HF RCRA Permit (DW Portion) that became effective on May 29, 1995. Closure certification was submitted to Ecology on September 22, 1995. On October 26, 1995, Ecology approved the clean closure certification. The Part A, Form 3, dangerous waste permit application documentation was stamped with "closed as of 10/26/95" and submitted to Ecology on November 28,1995 .

Compiled by: Waste Management Federal Services of Hanford, Inc.

Date: July 31, 1997 for Fluor Daniel Hanford, Inc. 
DOE Operations Office: Richland

DOE Facility: Hanford Site

Existing Permit (X) Renewal ( ) New Permit ( )

Permit Type: RCRA Closure Plan

Permitting Agency: Washington State Department of Ecology

Permit Number: WA7890008967

Permitted Unit: 2727-S Storage Facility

Issuance Date: September 28, 1994 (Date Revision 0 of the HF RCRA Permit became effective, 30 days after pemit issuance.)

Expiration Date: September 27, 2004

Need for Headquarters' Action

(for permit renewals or new permits)
Yes ( ) No (X)

If yes, HQ Program Element

Brief Summary of Relevant Information (major permit conditions, status of compliance or unusual problems):

Part A, Form 3, dangerous waste permit application documentation for the 2727-S Storage Facility originally was submitted to Ecology and the EPA in November 1985. Two revisions of the Part A, Form 3 , dangerous waste permit application documentation have been submitted.

The 2727-S Storage Facility Closure Plan originally was submitted to Ecology and the EPA in February 1989. Revision 3 of the 2727-S Storage Facility Closure Plan was incorporated into Revision 0 of the HF RCRA Permit (DW Portion) that became effective on September 28, 1994. Closure certification was submitted to Ecology on May 25, 1995. On June 27, 1995, Ecology approved the clean closure certification. The Part A. Form 3, dangerous waste permit application documentation was stamped with "closed as of 06/27/95" and submitted to Ecology on July 31, 1995.

Compiled by: Waste Management Federal Services of Hanford, Inc.

Date: July 31, 1997 for Fluor Daniel Hanford, Inc. 
DOE Operations Office: Richland

DOE Facility: Hanford Site

Existing Permit (X) Renewal ( ) New Permit ( )

Permit Type: RCRA Closure Plan

Permitting Agency: Washington State Department of Ecology

Permit Number: WA7890008967

Permitted Unit: 3718-F Alkali Metal Treatment and Storage Facility

Issuance Date:

Expiration Date:

Need for Headquarters' Action

(for permit renewals or new permits)
Yes ( ) No (X)

If yes, HQ Program Element

Brief Summary of Relevant Information (major permit conditions, status of compliance or unusual problems):

Part A, Form 3, and Part B dangerous waste permit application documentation for the 3718-F Alkali Metal Treatment and Storage Facility originally was submitted to Ecology and the EPA in November 1985. Four revisions of the Part A, Form 3, dangerous waste permit application documentation have been submitted.

Tri-Party Agreement Milestone M-20-18 was satisfied with the submittal of the 3718-F Alkali Metal Treatment and Storage Facility Closure Plan in December 1991. Revision 2 of the closure plan was submitted to Ecology on December 7, 1995, and approved by Ecology on January 30, 1996. The 3718-F Alkali Metal Treatment and Storage Facility was incorporated into Revision 3 of the HF RCRA Permit (DW Portion) that was effective in December 1996. At the time this unit was incorporated into the Permit, Ecology specified a requirement for soil sampling. Soil samples were collected on April 24, 1997. Closure of this unit is pending based on soil sampling results.

Compiled by: Waste Management Federal Services of Hanford, Inc. for Fluor Daniel Hanford, Inc.

Date: July 31, 1997 
DOE Operations Office: Richland

DOE Facility: Hanford Site

Existing Permit (X) Renewal ( ) New Permit ( )

Permit Type: RCRA Closure Plan

Permitting Agency: Washington State Department of Ecology

Permit Number: WA7890008967

Permitted Unit: 4843 Alkali Metal Storage Facility

Issuance Date:

Expiration Date:

Need for Headquarters' Action

(for permit renewals or new permits)
Yes ( ) No (X)

If yes, HQ Program Element

Brief Summary of Relevant Information (major permit conditions, status of compliance or unusual problems):

Part A, Form 3, dangerous waste permit application documentation for the 4843 Alkali Metal Storage Facility originally was submitted to Ecology and the EPA in September 1987. Three revisions of the Part A, Form 3, dangerous waste permit application documentation have been submitted.

The initial submittal of the 4843 Alkali Metal Storage Facility Closure Plan occurred in June 1991. Revision 1 of the 4843 Alkali Metal Storage Facility Closure Plan was submitted to Ecology in September 1995, and approved by Ecology on February 16, 1996. All dangerous waste was removed from the 4843 Aikali Metal Storage Facility by May 10, 1995. The 4843 Alkali Metal Storage Facility was incorporated into Revision 3 of the HF RCRA Permit (DW Portion) that was effective December 1996. On April 14,1997, Ecology approved the clean closure certification. The Part A, Form 3, dangerous waste permit application documentation was stamped. with "closed as of 04/14/97" and submitted to Ecology.

Compiled by: Waste Management Federal Services of Hanford, Inc.

Date: July 31, 1997 for Fluor Daniel Hanford, Inc. 
DOE Operations Office: Richland

DOE Facility: Hanford Site

Existing Permit ( ) Renewal ( ) New Permit (X)

Permit Type: RCRA

Permitting Agency: Washington State Department of Ecology

Permit Number: WA7890008967

Permitted Unit: B Plant Complex

Issuance Date:

Expiration Date:

Need for Headquarters' Action

(for permit renewals or new permits)
Yes ( ) No (X)

If yes, HQ Program Element

Brief Summary of Relevant Information (major permit conditions, status of compliance or unusual problems):

Part A, Form 3, dangerous waste permit application documentation for the B Plant Complex originally was submitted to Ecology and the EPA in November 1987. Five revisions of the Part A, Form 3 , dangerous waste permit application documentation have been submitted.

The B Plant Complex will be decommissioned and will not require Part B dangerous waste permit application documentation. As part of the transition-phase of decommissioning, Tri-Party Agreement Milestone M-20-21A will be satisfied with a preclosure work plan. Preparation of the preclosure work pian started in March 1997 with completion expected in March 1998.

Compiled by: Waste Management Federal Services of Hanford, Inc.

Date: July 31, 1997 for Fluor Daniel Hanford, Inc. 
DOE Operations Office: Richland

DOE Facility: Hanford Site

Existing Permit (X) Renewal ( ) New Permit ( )

Permit Type: RCRA Closure Plan

Permitting Agency: Washington State Department of Ecology

Permit Number: WA7890008967

Permitted Unit: Hanford Patrol Academy Demolition Sites

Issuance Date: September 28, 1995 (Date Revision 2 of he HF RCRA Permit became effective, 30 days after pemit issuance.)

Expiration Date: September 27, 2004

Need for Headquarters' Action

(for permit renewals or new permits)
Yes ( ) No (X)

If yes, HQ Program Element

Brief Summary of Relevant Information (major permit conditions, status of compliance or unusual problems):

Part A, Form 3, and Part B dangerous waste permit application documentation for the Hanford Patrol Academy Demolition Sites originally was submitted to Ecology and the EPA in November 1985. Subsequently, a decision was made to close this TSD unit. Four revisions of the. Part A. Form 3, dangerous waste permit application documentation have been submitted.

Tri-Party Agreement Milestone M-20-25 was satisfied with the submittal of the Hanford Patrol Academy Demolition Sites Closure Plan to Ecology and the EPA in November 1992. Revision 1 of the Hanford Patrol Academy Demolition Sites Closure Plan was incorporated into Revision 2 of the HF RCRA Permit (DW Portion) that became effective on September 28, 1995. Closure certification was submitted to Ecology on September 22, 1995. On October 26, 1995, Ecology approved the clean closure certification. The Part A, Form 3, dangerous waste permit application documentation was stamped with "closed as of 10/26/95" and submitted to Ecology on November 28, 1995.

Compiled by: Waste Management Federal Services of Hanford, Inc. for Fluor Daniel Hanford, Inc. 
DOE Operations Office: Richland

DOE Facility: Hanford Site

Existing Permit ( ) Renewal ( ) New Permit (X)

Permit Type: RCRA Closure Plan

Permitting Agency: Washington State Department of Ecology

Permit Number: WA7890008967

Permitted Unit: Hexone Storage and Treatment Facility

Issuance Date:

Expiration Date:

Need for Headquarters' Action

(for permit renewals or new permits)
Yes ( ) No (X)

If yes, HQ Program Element

Brief Summary of Relevant Information (major permit conditions, status of compliance or unusual problems):

Part A, Form 3, dangerous waste permit application documentation for the Hexone Storage and Treatment Facility originally was submitted to Ecology and the EPA in December 1987. Three revisions of the Part A, Form 3, dangerous waste permit application documentation have been submitted.

Tri-Party Agreement Milestone M-20-27 was satisfied with the submittal of the Hexone Storage and Treatment Facility Closure Plan to Ecology and the EPA in November 1992. Notice of Deficiency comments were received from Ecology on April 20, 1993. The Notice of Deficiency response table was submitted to Ecology and the EPA on July 19, 1993. The Template Notice of Deficiency response table is under review by the regulators.

Compiled by: Bechtel Hanford, Inc.

Date: July 31, 1997

Regulatory Support 


\section{DOE Operations Office: Richland}

DOE Facility: Hanford Site

Existing Permit ( ) Renewal ( ) New Permit (X)

Permit Type: RCRA Closure Plan

Permitting Agency: Washington State Department of Ecology

Permit Number: WA7890008967

Permitted Unit: PUREX Plant

Issuance Date:

Expiration Date:

Need for Headquarters' Action (for permit renewals or new permits)

\section{Yes ( ) No (X)}

If yes, HQ Program Element

Brief Summary of Relevant Information (major permit conditions, status of compliance or unusual problems):

Part A, Form 3, dangerous waste permit application documentation for the PUREX Plant originally was submitted to Ecology and the EPA in November 1987. Eight revisions of the Part A, Form 3, dangerous waste permit application documentation have been submitted.

Tri-Party Agreement Milestone M-20-24 required submittal of the Part B dangerous waste permit application documentation to Ecology and the EPA by September 1992. In December 1992, DOE-Headquarters determined that the PUREX Plant would no longer operate and directed the PUREX Facility to deactivate. Tri-Party Agreement Change Request M-80-94-01 was approved to support the PUREX Facility decommissioning and closure process. Tri-Party Agreement Milestone M-80-02 was fulfilled with the submittal of the following documentation: (1) PUREX Facility Preclosure Work Plan, July 12, 1996; (2) PUREX Facility Surveillance and Maintenance Plan, May 16, 1996; and (3) PUREX Facility End Point Criteria, June 21, 1995. Submittal of the PUREX Facility Preclosure Work Plan fulfilled Tri-Party Agreement Milestone M-20-24A.

In response to Ecology's comments, Revision 1 of the PUREX Facility Preclosure Work Plan was submitted on April 30, 1997.

Compiled by: Waste Management Federal Services of Hanford, Inc.

for Fluor Daniel Hanford, Inc.

Date: July 31, 1997 
DOE Operations Office: Richland

DOE Facility: Hanford Site

Existing Permit $(X) \quad$ Renewal ( ) New Permit ( )

Permit Type: RCRA Closure Plan

Permitting Agency: Washington State Department of Ecology

Permit Number: WA7890008967

Permitted Unit: Simulated High-Level Waste Slurry Treatment/Storage

Issuance Date: May 29, 1995 (Date Revision 1 of the HF RCRA Pemit became effective. 30 days after permit issuance.)

Expiration Date: September 27, 2004

Need for Headquarters' Action

(for permit renewals or new permits)
Yes ( ) No (X)

If yes, HQ Program Element

Brief Summary of Relevant Information (major permit conditions, status of compliance or unusual problems):

Part A, Form 3, dangerous waste permit application documentation for the Simulated High-Level Waste Slurry Treatment/Storage originally was submitted to Ecology and the EPA in May 1988. Two revisions of the Part A, Form 3, dangerous waste permit application documentation have been submitted.

Tri-Party Agreement Milestone M-20-19 was satisfied with the submittal of the Simulated High-Level Waste Slurry Treatment/Storage Closure Plan to Ecology and the EPA in September 1989. Revision 6 of the closure plan was submitted to Ecology and the EPA on July 29, 1994. Revision 6 of the Simulated High-Level Waste Slurry Treatment/Storage Closure Plan was incorporated into Revision l of the HF RCRA Permit (DW Portion) that became effective on May 29, 1995. Closure certification was submitted to Ecology on August 27, 1995. On September 6, 1995, Ecology approved the clean closure certification. The Part A, Form 3, dangerous waste permit application documentation was stamped with "closed as of 09/06/95" and submitted to Ecology on October 23, 1995.

Compiled by: Pacific Northwest National Laboratory

Date: July 31, 1997

Environmental Protection 


\section{RESOURCE CONSERVATION AND RECOVERY ACT CLOSURE AND POSTCLOSURE PLANS}


DOE/RL-96-63, Rev. 1

$10 / 97$

This page intentionally left blank. 
DOE Operations Office: Richland

DOE Facility: Hanford Site

Existing Permit (X) Renewal ( ) New Permit ( )

Permit Type: RCRA Closure/Postclosure Plan

Permitting Agency: Washington State Department of Ecology

Permit Number: WA7890008967

Permitted Unit: 183-H Solar Evaporation Basins

Issuance Date: September 28, 1994 (Date Revision o of hhe HF RCRA Permit became effective, 30 days after pemit issuance.)

Expiration Date: September 27, 2004

Need for Headquarters' Action

(for permit renewals or new permits)

Yes ( ) No (X)

If yes, HQ Program Element

Brief Summary of Relevant Information (major permit conditions, status of compliance or unusual problems):

Part A, Form 3, dangerous waste permit application documentation for the 183-H Solar Evaporation Basins originally was submitted to Ecology and the EPA in November 1985. Four revisions of the Part A, Form 3, dangerous waste permit application documentation have been submitted.

The 183-H Solar Evaporation Basins Closure Plan was submitted to Ecology and the EPA in June 1988. Revision 2 of the 183-H Solar Evaporation Basins Closure Plan was incorporated into Revision 0 of the HF RCRA Permit (DW Portion) that became effective on September 28, 1994. This unit was certified as closed on July 26.1996. Postclosure care will be required under a modified closure option. A postclosure plan was submitted to Ecology during December 1996 for inclusion in Modification $\mathrm{C}$ of the HF RCRA. Permit.

Compiled by: Bechtel Hanford, Inc.

Date: July 31, 1997

Regulatory Support 
DOE Operations Office: Richland

DOE Facility: Hanford Site

Existing Permit ( ) Renewal ( ) New Permit (X)

Permit Type: RCRA Closure and Postclosure Plan

Permitting Agency: Washington State Department of Ecology

U.S. Environmental Protection Agency, Region 10

Permit Number: WA7890008967

Permitted Unit: 216-A-10 Crib

Issuance Date:

Expiration Date:

Need for Headquarters' Action

(for permit renewals or new permits)
Yes ( ) No (X)

If yes, HQ Program Element

Brief Summary of Relevant Information (major permit conditions, status of compliance or unusual problems):

Part A, Form 3, dangerous waste permit application documentation for the 216-A-10 Crib originally was submitted to Ecology and the EPA in August 1987. Three revisions of the Part A, Form 3, dangerous waste permit application documentation have been submitted.

Tri-Party Agreement Milestone M-20-33 requires submittal of the 216-A-10 Crib Closure and Postclosure Plan to Ecology and the EPA by June 1998, coordinated with the past-practice documentation for the 200-PO-2 Operable Unit.

Compiled by: Bechtel Hanford, Inc.

Date: July 31, 1997

Regulatory Support 
DOE Operations Office: Richland

DOE Facility: Hanford Site

Existing Permit ( ) Renewal ( ) N New Permit (X)

Permit Type: RCRA Closure and Postclosure Plan

Permitting Agency: Washington State Department of Ecology

U.S. Environmental Protection Agency, Region 10

Permit Number: WA7890008967

Permitted Unit: 216-A-29 Ditch

Issuance Date:

Expiration Date:

Need for Headquarters' Action

(for permit renewals or new permits)
Yes ( ) No (X)

If yes, HQ Program Element

Brief Summary of Relevant Information (major permit conditions, status of compliance or unusual problems):

Part A, Form 3, dangerous waste permit application documentation for the 216-A-29 Ditch originally was submitted to Ecology and the EPA in August 1986. Three revisions of the Part A, Form 3, dangerous waste permit application documentation have been submitted.

The 216-A-29 Ditch Closure Plan originally was submitted to Ecology and the EPA in February 1988. Tri-Party Agreement Milestone M-20-36 was satisfied on April 3, 1995, with the submittal to Ecology and the EPA of the 216-A-29 Ditch Closure and Postclosure Plan coordinated with the past-practice documentation for the 200-BP-11 Operable Unit. The 216-A-29 Ditch is scheduled to be incorporated into the HF RCRA Permit (DW Portion) in Modification F, calendar year 2000.

Compiled by: Bechtel Hanford, Inc.

Date: July 31, 1997

Regulatory Support 
DOE Operations Office: Richland

DOE Facility: Hanford Site

Existing Permit ( ) Renewal ( ) New Permit (X)

Permit Type: RCRA Closure and Postclosure Plan

Permitting Agency: Washington State Department of Ecology

U.S. Environmental Protection Agency, Region 10

Permit Number: WA7890008967

Permitted Unit: ' 216-A-36B Crib

Issuance Date:

Expiration Date:

Need for Headquarters' Action (for permit renewals or new permits)

Yes ( ) No ( $X)$

If yes, HQ Program Element

Brief Surnmary of Relevant Information (major permit conditions, status of compliance or unusual problems):

Part A, Form 3, dangerous waste permit application documentation for the 216-A-36B Crib originally was submitted to Ecology and the EPA in February 1988. One revision of the Part A, Form 3, dangerous waste permit application documentation has been submitted.

The 216-A-36B Crib Closure Plan originally was submitted to Ecology and the EPA in February 1988. Tri-Party Agreement Milestone M-20-33 requires submittal of an updated closure and postclosure plan to Ecology and the EPA by June 1998, coordinated with the past-practice documentation for the 200-PO-2 Operable Unit.

Compiled by: Bechtel Hanford, Inc.

Date: July 31, 1997

Regulatory Support 
DOE Operations Office: Richland

DOE Facility: Hanford Site

Existing Permit ( ) Renewal ( ) New Permit (X)

Permit Type: RCRA Closure and Postclosure Plan

Permitting Agency: Washington State Department of Ecology

U.S. Environmental Protection Agency, Region 10

Permit Number: WA7890008967

Permitted Unit: 216-A-37-1 Crib

Issuance Date:

Expiration Date:

Need for Headquarters' Action

(for permit renewals or new permits)
Yes ( ) No (X)

If yes, HQ Program Element

Brief Summary of Relevant Information (major permit conditions, status of compliance or unusual problems):

Part A, Form 3, dangerous waste permit application documentation for the 216-A-37-1 Crib originally was submitted to Ecology and the EPA in February 1990. Two revisions of the Part A, Form 3, dangerous waste permit application documentation have been submitted.

Tri-Party Agreement Milestone M-20-52 was established to coordinate the 216-A-37-1 Crib Closure and Postclosure Plan with the past-practice documentation for the 200-PO-4 Operable Unit. The submittal date for this documentation is October 1998.

Compiled by: Bechtel Hanford, Inc.

Date: July 31, 1997

Regulatory Support 
DOE Operations Office: Richland

DOE Facility: Hanford Site

Existing Permit ( ) Renewal ( ) New Permit (X)

Permit Type: RCRA Closure and Postclosure Plan

Permitting Agency: Washington State Department of Ecology

U.S. Environmental Protection Agency, Region 10

Permit Number: WA7890008967

Permitted Unit: 216-B-3 Main Pond and 216-B-3-3 Ditch

Issuance Date:

Expiration Date:

Need for Headquarters' Action

(for permit renewals or new permits)
Yes ( ) No ( $X$ )

If yes, HQ Program Element

Brief Summary of Relevant Information (major permit conditions, status of compliance or unusual problems):

Originally the 216-B-3 Expansion Ponds were included with the 216-B-3 Pond Main Lobe, in a single Part A, Form 3, dangerous waste permit application documentation. In December 1993, the 216-B-3 Pond System Part A, Form 3, was separated into two Part A, Form 3s: one for the 216-B-3 Expansion Ponds and one for the 216-B-3 Main Pond and 216-B-3-3 Ditch. Five revisions of the Part A, Form 3, dangerous waste permit application documentation have been submitted.

Tri-Party Agreement Milestone M-13-07 directed the closure of the 216-B-3 Main Pond and 216-B-3-3 Ditch coordinated with RCRA past-practice activities at the 200-BP-11 Operable Unit. The coordinated work and submittal of the closure plan were completed September 30, 1994. To address the recently increased scope of the 200-BP-11 Operable Unit, draft B of the document was submitted to Ecology and the EPA in April 1995 to meet Milestone M-20-36. The 216-B-3 Main Pond and 216-B-3-3 Ditch is scheduled to be incorporated into the HF RCRA Permit (DW Portion) in Modification F, calendar year 2000.

Compiled by: Bechtel Hanford, Inc.

Date: July 31, 1997

Regulatory Support 
DOE Operations Office: Richland

DOE Facility: Hanford Site

Existing Permit ( ) Renewal ( ) New Permit (X)

Permit Type: RCRA Closure and Postclosure Plan

Permitting Agency: Washington State Department of Ecology

U.S. Environmental Protection Agency, Region 10

Permit Number: WA7890008967

Permitted Unit: 216-U-12 Crib

Issuance Date:

Expiration Date:

Need for Headquarters' Action

(for permit renewals or new permits)
Yes ( ) No ( $\mathrm{X}$ )

If yes, HQ Program Element

Brief Summary of Relevant Information (major permit conditions, status of compliance or unusual problems):

Part A, Form 3, dangerous waste permit application documentation for the 216-U-i2 Crib originally was submitted to Ecology and the EPA in August 1987. Three revisions of the Part A, Form 3, dangerous waste permit application documentation have been submitted.

Tri-Party Agreement Milestone M-20-37 was satisfied on June 27, 1995, with the submittal to Ecology and the EPA of the 216-U-12 Crib Closure and Postclosure Plan coordinated with the past-practice documentation for the 200-UP-2 Operable Unit. Currently, the 216-U-12 Crib is not scheduled to be incorporated into the HF RCRA Permit (DW Portion) until after the year 2000.

Compiled by: Bechtel Hanford, Inc.

Date: July 31, 1997

Regulatory Support 
DOE Operations Office: Richland

DOE Facility: Hanford Site

Existing Permit ( ) Renewal ( ) New Permit (X)

Permit Type: RCRA Closure and Postclosure Plan

Permitting Agency: Washington State Department of Ecology

U.S. Environmental Protection Agency, Region 10

Permit Number: WA7890008967

Permitted Unit: 241-CX Tank System

Issuance Date:

Expiration Date:

Need for Headquarters' Action

(for permit renewals or new permits)
Yes ( ) No (X)

If yes, HQ Program Element

Brief Summary of Relevant Information (major permit conditions, status of compliance or unusual problems):

Part A, Form 3, dangerous waste permit application documentation for the 241-CX Tank System originally was submitted to Ecology and the EPA in July 1990. Three revisions of the Part A, Form 3, dangerous waste permit application documentation have been submitted.

A Tri-Party Agreement change request is being prepared to coordinate the 241-CX Tank System Closure Plan with the past-practice documentation for the 200-SO-1 Operable Unit. The submittal date for this documentation will be negotiated with Ecology and the EPA.

Compiled by: Bechtel Hanford, Inc.

Date: July 31, 1997

Regulatory Support 
DOE Operations Office: Richland

DOE Facility: Hanford Site

Existing Permit (X) Renewal ( ) New Permit ( )

Permit Type: RCRA Closure and Postclosure Plan

Permitting Agency: Washington State Department of Ecology

U.S. Environmental Protection Agency, Region 10

Permit Number: WA7890008967

Permitted Unit: 300 Area Process Trenches

Issuance Date:

Expiration Date:

Need for Headquarters' Action

(for permit renewals or new permits)
Yes ( ) No (X)

If yes, HQ Program Element

Brief Summary of Relevant Information (major permit conditions, status of compliance or unusual problems):

Part A, Form 3, dangerous waste permit application documentation for the 300 Area Process Trenches originally was submitted to Ecology and the EPA in November 1985. Four revisions of the Part A, Form 3, dangerous waste permit application documentation have been submitted.

Tri-Party Agreement Milestone M-20-32 was satisfied on August 15, 1994, with the submittal to Ecology and the EPA of an updated closure and postclosure plan. The 300 Area Process Trenches were incorporated into Revision 3 of the HF RCRA Permit (DW Portion) as a modified closure that was effective in December 1996. The conditions and requirements are contained in Part VI, Chapter 1 of the HF RCRA Permit.

Compiled by: Bechtel Hanford, Inc.

Date: July 31, 1997

Regulatory Support 
DOE Operations Office: Richland

DOE Facility: Hanford Site

Existing Permit ( ) Renewal ( ) New Permit (X)

Permit Type: RCRA Closure and Postclosure Plan

Permitting Agency: Washington State Department of Ecology

U.S. Environmental Protection Agency, Region 10

Permit Number: WA7890008967

Permitted Unit: 1301-N Liquid Waste Disposal Facility

Issuance Date:

Expiration Date:

Need for Headquarters' Action

(for permit renewals or new permits)
Yes ( ) No (X)

If yes, HQ Program Element

Brief Summary of Relevant Information (major permit conditions, status of compliance or unusual problems):

Part A, Form 3, dangerous waste permit application documentation for the 1301-N Liquid Waste Disposal Facility originally was submitted to Ecology and the EPA in August 1986; documentation for the 1325-N Liquid Waste Disposal Facility originally was submitted in February 1987. Seven revisions of the Part A, Form 3, dangerous waste permit application documentation have been submitted.

Tri-Party Agreement Milestone M-20-31 required the submittal of an updated $1301-\mathrm{N}$ and 1325-N Liquid Waste Disposal Facility Closure and Postclosure Plan to Ecology and the EPA by May 31, 1994. Tri-Party Agreement change request M-20-94-01 was approved on May 20, 1994, changing the submittal date of the updated closure and postclosure plan to a "to be determined." This unit will be included as an attachment to the corrective measures study for the 100-N Area TSD units. The 1301-N Liquid Waste Disposal Facility is scheduled to be incorporated into the HF RCRA Permit (DW Portion) in Modification E, calendar year 1999.

Compiled by: Bechtel Hanford, Inc.

Date: July 31, 1997

Regulatory Support 
DOE Operations Office: Richland

DOE Facility: Hanford Site

Existing Permit ( ) Renewal ( ) New Permit (X)

Permit Type: RCRA Closure and Postclosure Plan

Permitting Agency: Washington State Department of Ecology

U.S. Environmental Protection Agency, Region 10

Permit Number: WA7890008967

Permitted Unit: $1325-\mathrm{N}$ Liquid Waste Disposal Facility

Issuance Date:

Expiration Date:

Need for Headquarters' Action

(for permit renewals or new permits)
Yes ( ) No (X)

If yes, HQ Program Element

Brief Summary of Relevant Information (major permit conditions, status of compliance or unusual problems):

Part A, Form 3, dangerous waste permit application documentation for the 1301-N Liquid Waste Disposal Facility originally was submitted to Ecology and the EPA in August 1986; documentation for the 1325-N Liquid Waste Disposal Facility originally was submitted in February 1987. Seven revisions of the Part A, Form 3, dangerous waste permit application documentation have been submitted.

Tri-Party Agreement Milestone M-20-31 required the submittal of an updated 1301-N and 1325-N Liquid Waste Disposal Facility Closure and Postclosure Plan to Ecology and the EPA by May 31, 1994. Tri-Party Agreement change request M-20-94-01 was approved on May 20, 1994, changing the submittal date of the updated closure and postclosure plan to a "to be determined." This unit will be included as an attachment to the corrective measures study for the 100-N Area TSD units. The 1325-N Liquid Waste Disposal Facility is scheduled to be incorporated into the HF RCRA Permit (DW Portion) in Modification E, calendar year 1999.

Compiled by: Bechtel Hanford, Inc.

Date: July 31, 1997

Regulatory Support 
DOE Operations Office: Richland

DOE Facility: Hanford Site

Existing Permit ( ) Renewal ( ) N $\quad$ New Permit (X)

Permit Type: RCRA Closure and Postclosure Plan

Permitting Agency: Washington State Department of Ecology

Permit Number: WA7890008967

Permitted Unit: Nonradioactive Dangerous Waste Landfill

Issuance Date:

Expiration Date:

Need for Headquarters' Action

(for permit renewals or new permits)
Yes ( ) No (X)

If yes, HQ Program Element

Brief Summary of Relevant Information (major permit conditions, status of compliance or unusual problems):

Part A, Form 3, and Part B dangerous waste permit application documentation for the Nonradioactive Dangerous Waste Landfill originally was submitted to Ecology and the EPA in November 1985. Subsequently, a decision was made to close this TSD unit. Four revisions of the Part A, Form 3, dangerous waste permit application documentation have been submitted.

Tri-Party Agreement Milestone M-20-07 was satisfied with the submittal of the Nonradioactive Dangerous Waste Landfill Closure and Postclosure Plan to Ecology and the EPA in August 1990. Ecology has requested that the DOE-RL evaluate clean closure. All information requested on clean closure has been reviewed by the regulatory agencies. Ecology issued partial Notice of Deficiency comments in January 1994. A Notice of Deficiency response table is being prepared to address the January" 1994 comments.

Compiled by: Bechtel Hanford, Inc.

Date: July 31, 1997

Regulatory Support 


\section{RESOURCE CONSERVATION AND RECOVERY ACT}

\section{CLOSURE WORK PLAN}


DOE/RL-96-63, Rev. 1

$10 / 97$

This page intentionally left blank. 
DOE Operations Office: Richland

DOE Facility: Hanford Site

Existing Permit ( ) Renewal ( ) New Permit (X)

Permit Type: RCRA Closure and Corrective Action Work Plan

Permitting Agency: Washington State Department of Ecology

Permit Number: WA7890008967

Permitted Unit: Single-Shell Tank System

Issuance Date:

Expiration Date:

Need for Headquarters' Action

(for permit renewals or new permits)
Yes ( ) No (X)

If yes, HQ Program Element

Brief Summary of Relevant Information (major permit conditions, status of compliance or unusual problems):

Part A, Form 3, dangerous waste permit application documentation for the Single-Shell Tank System originally was submitted to Ecology and the EPA in February 1988. Four revisions of the Part A, Form 3, dangerous waste permit application documentation have been submitted.

Tri-Party Agreement Milestone M-20-03 was satisfied with the submittal of the Single-Shell Tank System Closure Work Plan to Ecology and the EPA in September 1989. A revised closure work plan was provided to Ecology on June 13, 1995, in accordance with Tri-Party Agreement Milestone M-45-06. Ecology provided Notice of Deficiency comments on March 6, 1996. The Notice of Deficiency comments were resolved in April 1996. Revision l of the closure work plan was submitted to Ecology in May 1996. Revision 2 of the closure work plan is scheduled to be prepared during fiscal year 1998.

Compiled by: Waste Management Federal Services of Hanford, Inc.

Date: July 31, 1997 for Fluor Daniel Hanford, Inc. 
This page intentionally left blank. 


\section{RESOURCE CONSERVATION AND RECOVERY ACT DELISTING PETITION}


DOE/RL-96-63, Rev. 1

$10 / 97$

This page intentionally left blank. 
DOE Operations Office: Richland

DOE Facility: Hanford Site

Existing Permit (X) Renewal ( ) New Permit ( )

Permit Type: Delisting Approval - 40 CFR 260.20 and 260.22

Permitting Agency: U.S. Environmental Protection Agency, Region 10

Permit Number: N/A

Permitted Unit: 200 Area Effluent Treatment Facility

Issuance Date: June 13, 1995

Expiration Date: N/A

Need for Headquarters' Action

Yes ( ) No (X)

(for permit renewals or new permits)

If yes, HQ Program Element

Brief Summary of Relevant Information (major permit conditions, status of compliance or unusual problems):

The 200 Area Effluent Treatment Facility Delisting Petition originally was submitted to the EPA in October 1992, with supporting documentation submitted in August 1993. Submittal of this delisting petition and a State Waste Discharge permit application in August of 1993 satisfied Consent Order DE 91NM-177 requirements for discharge of liquid effluent from the Effluent Treatment Facility to the soil column.

The delisting petition was prepared to exempt the treated effluent from the 200 Area Effluent Treatment Facility from Subtitle C of RCRA. The delisting conditions include verification testing and monitoring requirements. Delisting enables disposal of the treated effluent to a State Approved Land Disposal Site. The EPA gave notice of their approval of the delisting petition in the Federal Register dated June 13, 1995.

Compiled by: Waste Management Federal Services of Hanford, Inc.

Date: July 31, 1997 for Fluor Daniel Hanford, Inc. 
DOE/RL-96-63, Rev. 1

This page intentionally left blank. 
SOLD WASTE HANDLING PERMITTING 
This page intentionally left blank. 
DOE Operations Office: Richland

DOE Facility: Hanford Site

Existing Permit ( ) Renewal ( ) New Permit (X)

Permit Type: Solid Waste Handling Permit - WAC 173-304

Permitting Agency: Washington State Department of Ecology

Permit Number: N/A

Permitted Unit: Solid Waste Landfill

Issuance Date: N/A

Expiration Date: N/A

Need for Headquarters' Action

(for permit renewals or new permits)
Yes ( ) No ( $\mathrm{X}$ )

If yes, HQ Program Element

Brief Summary of Relevant Information (major permit conditions, status of compliance or unusual problems):

The Solid Waste Handling Permit would have allowed disposal of nonhazardous, nonradioactive waste in the Solid Waste Landfill, located in the 600 Area. north of the Wye Barricade. The application was submitted to Ecology in November 1993. Ecology denied the application for a Solid Waste Handling Permit to operate the Solid Waste Landfill on March 14, 1995, since groundwater contamination had been detected in the underlying aquifer.

Ecology agreed that DOE-RL could continue interim operation of the landfill in the absence of a permit if a target shutdown date for the Solid Waste landfill was submitted and approved by Ecology. A target shutdown date of March 31, 1996, was submitted to Ecology and approved. The Solid Waste Landfill ceased operations on March 31, 1996. An interim closure plan, Hanford Site Solid Waste Landfill Interim Closure Plan, was prepared and submitted to Ecology on July 9, 1996. Groundwater and soil gas monitoring continue.

Compiled by: Waste Management Federal Services of Hanford, Inc.

Date: July 31, 1997

for Fluor Daniel Hanford, Inc. 
DOE/RL-96-63, Rev. 1

$10 / 97$

This page intentionally left blank. 
DOE/RL-96-63, Rev. 1

10/97

\section{CLEAN AIR ACT PERMITTING}


DOE/RL-96-63, Rev. 1

This page intentionally left blank. 
DOE Operations Office: Richland

DOE Facility: Hanford Site

Existing Permit (X) Renewal ( ) New Permit ( )

Permit Type: Radioactive Air Emissions Program, Radioactive Source Registration WAC 246-247

Permitting Agency: Washington State Department of Health

Permit Number: FF-01

Permitted Unit: Hanford Site (Radioactive Air Emissions Program)

Issuance Date: August 15, 1993

Expiration Date: August 15, 1997, or when replaced by air operating permit

Need for Headquarters' Action

(for permit renewals or new permits)

\section{Yes ( ) No (X)}

If yes, HQ Program Element

Brief Summary of Relevant Information (major permit conditions, status of compliance or unusual problems):

This permit governs the operations of the emission sources in the 100,200,300,400, and 600 Areas of the Hanford Site related to fuel reprocessing; radioactive waste handling; and disposal, research and development, and other nuclear operations having the potential to emit airborne radioactivity in excess or equal to 10 percent of the derived concentration guideline values. The major permit conditions include discharge points, efficiency values for control devices, effluent limitations on a daily and yearly basis, and continuous monitoring requirements.

Compiled by: Waste Management Federal Services of Hanford, Inc.

Date: July 31, 1997 for Fluor Daniel Hanford, Inc. 
DOE Operations Office: Richland

DOE Facility: Hanford Site

Existing Permit ( )

Renewal ( )

New Permit $(X)$

Permit Type: Title V Operating Permit - 40 CFR 70

Permitting Agency: Washington State Department of Ecology

Washington State Department of Health

U.S. Environmental Protection Agency, Region 10

Permit Number: TBD

Permitted Unit: Hanford Site (Title V Operating Permit)

Issuance Date: TBD

Expiration Date: TBD

Need for Headquarters' Action

Yes ( ) No (X)

(for permit renewals or new permits)

If yes, HQ Program Element

Brief Summary of Relevant Information (major permit conditions, status of compliance or unusual problems):

The permit will list regulated pollutants emitted, identify and describe emission points (except insignificant emission units), provide emission rates, and describe fuels and other inputs or factors relating to emissions and emission control equipment. Radioactive and nonradioactive sources will be included. The permit application was submitted to Ecology and to the Department of Health on May 25, 1995. Amendments to the permit application maintain the application current. The permit is scheduled to be issued by Ecology the first quarter of calendar year 1998.

Compiled by: Waste Management Federal Services of Hanford, Inc. for Fluor Daniel Hanford, Inc.

Date:- July 31, 1997 
DOE Operations Office: Richland

DOE Facility: Hanford Site

Existing Permit (X) Renewal ( ) New Permit ( )

Permit Type: Radioactive Air Emissions Program Notice of Construction - WAC 246-247

Permitting Agency: Washington State Department of Health

Permit Number: Routine Technical Assistance Meeting

Permitted Unit: 100-K Basins Dose Reduction Activities

Issuance Date: January 9, 1996

Expiration Date: NA

Need for Headquarters' Action

(for permit renewals or new permits)
Yes ( ) No ( $\mathrm{X}$ )

If yes, HQ Program Element

Brief Summary of Relevant Information (major permit conditions, status of compliance or unusual problems):

Meeting minutes from the Routine Technical Assistance Meeting of January 9, 1996, contain descriptions of activities contained in the Debris Removal Notice of Construction for the 105-K East Basin. The 105-K East Fuel Removal Notice of Construction. DOE/RL-96-101, superseded the previously approved Debris Removal Notice of Construction for the 105-K East Basin.

There are no compliance issues, major permit conditions, or unusual problems associated with this project as of July 1997.

Compiled by: Waste Management Federal Services of Hanford, Inc. for Fluor Daniel Hanford, Inc. 
DOE Operations Office: Richland

DOE Facility: Hanford Site

Existing Permit ( ) Renewal ( ) New Permit (X)

Permit Type: Radioactive Air Emissions Program Notice of Construction - WAC 246-247

Permitting Agency: Washington State Department of Health

Permit Number: Routine Technical Assistance Meeting

Permitted Unit: $100-\mathrm{K}$ Basins Phase 2 Characterization

Issuance Date: January 9, 1996

Expiration Date: NA

Need for Headquarters' Action

(for permit renewals or new permits)

Yes ( ) No (X)

If yes, HQ Program Element

Brief Summary of Relevant Information (major permit conditions, status of compliance or unusual problems):

Meeting minutes from the Routine Technical Assistance Meeting of January 9, 1996, contains a description of activities. These activities, for the most part, provide for extensions of previously approved characterization activities. In the $\mathrm{K}$-West Basin, gas and liquid samples will be obtained in addition to fuel element and canister sludge samples. In K-East Basin, fuel elements and canister samples will be obtained. All samples will be shipped via cask to the analytical facilities.

There are no compliance issues, major permit conditions, or unusual problems associated with this project as of July 1997.

Compiled by: Waste Management Federal Services of Hanford, Inc.

Date: July 31, 1997 for Fluor Daniel Hanford, Inc. 
DOE Operations Office: Richland

DOE Facility: Hanford Site
Existing Permit ( )
Renewal ( )
New Permit ( X)

Permit Type: Radioactive Air Emissions Program Notice of Construction - WAC 246-247

Permitting Agency: Washington State Department of Health

Permit Number: Routine Technical Assistance Meeting

Permitted Unit: 100-K East Basin Air Sampling Equipment Reduction

Issuance Date: August 9, 1995

Expiration Date: NA

Need for Headquarters' Action

(for permit renewals or new permits)
Yes ( ) No (X)

If yes, HQ Program Element

Brief Summary of Relevant Information (major permit conditions, status of compliance or unusual problems):

Meeting minutes from the Routine Technical Assistance Meeting of August 8, 1995, provide for the approval for halting the use of the high bay air monitor. This was approved with the condition that the monitor be left in place so that operation of the monitor could be required during future activities in the basin, if a need was identified.

There were no compliance issues, major permit conditions, or unusual problems associated with this project as of July 1997.

Compiled by: Waste Management Federal Services of Hanford, Inc.

Date: July 31, 1997 for Fluor Daniel Hanford, Inc. 
DOE Operations Office: Richland

DOE Facility: Hanford Site

Existing Permit ( ) Renewal ( ) New Permit (X)

Permit Type: Radioactive Air Emissions Program Notice of Construction - WAC 246-247

Permitting Agency: Washington State Department of Health

Permit Number: AIR 96-802

Permitted Unit: $105-C$ Reactor Interim Safe Storage

Issuance Date: August 12, 1996

Expiration Date: N/A

Need for Headquarters' Action

(for permit renewals or new permits)

\section{Yes ( ) No (X)}

If yes, HQ Program Element

Brief Summary of Relevant Information (major permit conditions, status of compliance or unusual problems):

Approval of this Notice of Construction allows for the decontamination and demolition of unnecessary structures at the 105-C Reactor and the construction of the interim safe storage enclosure for the 105-C Reactor block. Approval was received August 12, 1996, and work is in progress.

Compiled by: Bechtel Hanford, Inc.

Date: July 31, 1997.

Regulatory Support 
DOE Operations Office: Richland

DOE Facility: Hanford Site

Existing Permit ( ) Renewal ( ) New Permit (X)

Permit Type: National Emission Standard for Hazardous Air Pollutants (NESHAPs) 40 CFR 61, Subpart H

Permitting Agency: U.S. Environmental Protection Agency, Region 10

Permit Number: N/A

Permitted Unit: $105-C$ Reactor Interim Safe Storage

Issuance Date: September 3, 1996

Expiration Date: N/A

Need for Headquarters' Action

(for permit renewals or new permits)
Yes ( ) No ( $X$ )

If yes, HQ Program Element

Brief Summary of Relevant Information (major permit conditions, status of compliance or unusual problems):

Approval of this application allows for the decontamination and demolition of unnecessary structures at the 105-C Reactor and the construction of the interim safe storage enclosure for the 105-C Reactor block. Approval was received September 3, 1996, and work is in progress.

Compiled by: Bechtel Hanford, Inc.

Date: July 31, 1997

Regulatory Support 
DOE Operations Office: Richland

DOE Facility: Hanford Site

Existing Permit ( ) Renewal ( ) N New Permit (X)

Permit Type: Radiological Air Emissions Program Notice of Construction - WAC 246-247

Permitting Agency: Washington State Department of Health

Permit Number: Routine Technical Assistance Meeting, October 8, 1996

Permitted Unit: 105-K East and 105-K West Basin Entryway Modifications

Issuance Date: October 8, 1996 .

Expiration Date: N/A

Need for Headquarters' Action

(for permit renewals or new permits)
Yes ( ) No (X)

If yes, HQ Program Element

Brief Summary of Relevant Information (major permit conditions, status of compliance or unusual problems):

Approval of this Notice of Construction for 105-K East and 105-K West Basin entryway modifications includes contaminated building structure and structural steel and tubing, light fixtures, and other items.

There are no compliance issues, major permit conditions, or unusual problems associated with this project as of July 1997.

Compiled by: Waste Management Federal Services of Hanford, Inc.

Date: July 31, 1997 for Fluor Daniel Hanford, Inc. 
DOE Operations Office: Richland

DOE Facility: Hanford Site

Existing Permit ( )

Renewal ( )

New Permit (X)

Permit Type: National Emission Standards for Hazardous Air Pollutants (NESHAPs) 40 CFR 61, Subpart H

Permitting Agency: U.S. Environmental Protection Agency, Region 10

Permit Number: EPA letter dated December 20, 1996

Permitted Unit: $105-\mathrm{K}$ East and 105-K West Corridor 7 Modifications

Issuance Date: December 20, 1996

Expiration Date: N/A

Need for Headquarters' Action

(for permit renewals or new permits)
Yes ( ) No (X)

If yes, HQ Program Element

Brief Summary of Relevant Information (major permit conditions, status of compliance or unusual problems):

Approval of this application for Corridor 7 includes modification activities similar to those described in a previously approved Notice of Construction for 105-K East Basin Debris Removal. The monitoring described in the Notice of Construction would be the current monitoring plus any additional health physics technician required monitoring, as necessary.

There are no compliance issues, major permit conditions, or unusual problems associated with this project as of July 1997.

Compiled by: Waste Management Federal Services of Hanford, Inc.

Date: July 31, 1997 for Fluor Daniel Hanford, Inc. 
DOE Operations Office: Richland

DOE Facility: Hanford Site

Existing Permit ( ) Renewal ( ) New Permit (X)

Permit Type: National Emission Standards for Hazardous Air Pollutants (NESHAPs) 40 CFR 61, Subpart H

Permitting Agency: U.S. Environmental Protection Agency, Region 10

Permit Number: Letter dated October 22, 1996

Permitted Unit: 105-K East and 105-K West Demolition Activities

Issuance Date: October 22, 1996

Expiration Date: N/A

Need for Headquarters' Action

(for permit renewals or new permits)
Yes ( ) No (X)

If yes, HQ Program Element

Brief Summary of Relevant Information (major permit conditions, status of compliance or unusual problems):

Letter approval concerns three applications for 105-K East and 105-K West demolition activities, and 105-K East Basin chiller removal.

There are no compliance issues, major permit conditions, or unusual problems associated with this project as of July 1997.

Compiled by: Waste Management Federal Services of Hanford, Inc. for Fluor Daniel Hanford, Inc.

Date: July 31, 1997 
DOE Operations Office: Richland

DOE Facility: Hanford Site

Existing Permit ( ) Renewal ( ) New Permit (X)

Permit Type: National Emission Standards for Hazardous Air Pollutants (NESHAPs) 40 CFR 61, Subpart H

Permitting Agency: U.S. Environmental Protection Agency, Region 10

Permit Number: EPA letter dated December 20, 1996

Permitted Unit: 105-K East and 105-K West Entrance Vestibule Modifications

Issuance Date: December 20, 1996

Expiration Date: N/A

Need for Headquarters' Action

(for permit renewals or new permits)
Yes ( ) No (X)

If yes, HQ Program Element

Brief Summary of Relevant Information (major permit conditions, status of compliance or unusual problems):

Approval of this application is to construct or modify the 105-K East and 105-K West Basin entrance vestibule.

There are no compliance issues, major permit conditions, or unusual problems associated with this project as of July 1997.

Compiled by: Waste Management Federal Services of Hanford, Inc.

Date: July 31, 1997 for Fluor Daniel Hanford, Inc. 
DOE Operations Office: Richland

DOE Facility: Hanford Site

Existing Permit ( )

Renewal ( )

New Permit ( $X)$

Permit Type: Radiological Air Emissions Program Notice of Construction - WAC 246-247

Permitting Agency: Washington State Department of Health

Permit Number: Routine Technical Assistance Meeting, February 11, 1997

Permitted Unit: 105-K East and 105-K West Fuel Hangar Removal Activity

Issuance Date: February 11, 1997

Expiration Date: N/A

Need for Headquarters' Action

(for permit renewals or new permits)

Yes ( ) No (X)

If yes, HQ Program Element

Brief Summary of Relevant Information (major permit conditions, status of compliance or unusual problems):

Approval of this Notice of Construction provides for the removal of the 105-K East and 105-K West Basin hangar removal. This project will remove the remaining 9 fuel hangars and 12 long poles from the 105-K West Basin and the 62 hangars from the 105-K East Basin. The items to be removed are approximately 6.1 meters long and 2.54 centimeters in diameter. None of the items have been immersed into basin sludge. These items will be cut up, packaged, and disposed as low-level waste.

There are no compliance issues, major permit conditions, or unusual problems associated with this project as of July 1997.

Compiled by: Waste Management Federal Services of Hanford, Inc.

Date: July 31, 1997 for Fluor Daniel Hanford, Inc. 
DOE Operations Office: Richland

DOE Facility: Hanford Site

Existing Permit ( ) Renewal ( ) New Permit (X)

Permit Type: Radiological Air Emissions Program Notice of Construction - WAC 246-247

Permitting Agency: Washington State Department of Health

Permit Number: AIR 97-206

Permitted Unit: 105-K East Basin

Issuance Date: March 5, 1997

Expiration Date: N/A

Need for Headquarters' Action (for permit renewals or new permits)

Yes ( ) No (X)

If yes, HQ Program Element

Brief Summary of Relevant Information (major permit conditions, status of compliance or unusual problems):

This Notice of Construction provides for the installation, operation, and maintenance of spent nuclear fuel removal and sludge relocation equipment; transport of fuel and residual sludge on the fuel in multi-canister overpacks to the Cold Vacuum Drying Facility; and debris removal and minor basin modifications.

There are no compliance issues, major permit conditions, or unusual problems associated with this project as of July 1997.

Compiled by: Waste Management Federal Services of Hanford, Inc.

Date: July 31, 1997 for Fluor Daniel Hanford, Inc. 
DOE Operations Office: Richland

DOE Facility: Hanford Site

Existing Permit ( ) Renewal ( ) New Permit (X)

Permit Type: Radiological Air Emissions Program Notice of Construction - WAC 246-247

Permitting Agency: Washington State Department of Health

Permit Number: Routine Technical Assistance Meeting, September 10, 1996

Permitted Unit: 105-K East Basin Chiller and Heat Exchanger Removal Activity

. Issuance Date: September 10, 1996

Expiration Date: N/A

Need for Headquarters' Action

(for permit renewals or new permits)

Yes ( ) No (X)

If yes, HQ Program Element

Brief Summary of Relevant Information (major permit conditions, status of compliance or unusual problems):

Approval of this Notice of Construction provides for the removal of the 105-K East Basin chiller and heat exchanger. Cleaning of the heat exchanger interior uses either a glove bag or other containment such that the cleaning activity would not be an open air operation.

There are no compliance issues, major permit conditions, or unusual problems associated with this project as of July 1997.

Compiled by: Waste Management Federal Services of Hanford, Inc. for Fluor Daniel Hanford, Inc. 
DOE Operations Office: Richland

DOE Facility: Hanford Site

Existing Permit (X) Renewal ( ) New Permit ( )

Permit Type: Radioactive Air Emissions Program Notice of Construction - WAC 246-247

Permitting Agency: Washington State Department of Health

Permit Number: AIR-95-1001

Permitted Unit: 105-K East Basin Debris Removal

Issuance Date: October 3, 1995

Expiration Date: N/A

Need for Headquarters' Action

(for permit renewals or new permits)

Yes ( ) No (X)

If yes, HQ Program Element

Brief Summary of Relevant Information (major permit conditions, status of compliance or unusual problems):

Approval of this Notice of Construction allows removal of debris from the 105-K East Basin. Approval was granted, subject to the condition that the activity is conducted in accordance with descriptions contained in the application.

There are no compliance issues, major permit conditions, or unusual problems associated with this project as of July 1997.

Compiled by: Waste Management Federal Services of Hanford, Inc.

Date: July 31,1997 for Fluor Daniel Hanford, Inc. 
DOE Operations Office: Richland

DOE Facility: Hanford Site

Existing Permit (X) Renewal ( ) New Permit ( )

Permit Type: National Emission Standard for Hazardous Air Pollutants (NESHAPs) 40 CFR 61, Subpart H

Permitting Agency: U.S. Environmental Protection Agency, Region 10

Permit Number: N/A

Permitted Unit: 105-K East Basin Debris Removal

Issuance Date: August 28, 1995

Expiration Date: N/A

Need for Headquarters' Action

(for permit renewals or new permits)
Yes ( ) No (X)

If yes, HQ Program Element

Brief Summary of Relevant Information (major permit conditions, status of compliance or unusual problems):

Approval of this application allows removal of debris from the 105-K East Basin. Approval was granted, subject to the condition that the activity is conducted in accordance with descriptions contained in the permit application.

There are no compliance issues, major permit conditions, or unusual problems associated with this project as of July 1997.

Compiled by: Waste Management Federal Services of Hanford, Inc. for Fluor Daniel Hanford, Inc. 
DOE Operations Office: Richland

DOE Facility: Hanford Site

Existing Permit ( ) Renewal ( ) New Permit (X)

Permit Type: Radiological Air Emissions Program Notice of Construction - WAC 246-247

Permitting Agency: Washington State Department of Health

Permit Number: Routine Technical Assistance Meeting Minutes for November 12, 1996

Permitted Unit: 105-K East Basin Hydrolasing

Issuance Date: November 12, 1996

Expiration Date: N/A

Need for Headquarters' Action

(for permit renewals or new permits)
Yes ( ) No (X)

If yes, HQ Program Element

Brief Summary of Relevant Information (major permit conditions, status of compliance or unusual problems):

The Notice of Construction was approved to clean the interior of about 1500 feet of 2 to 8 inch diameter water treatment piping using the hydrolasing method. Hydrolasing may need to be performed every year. The basin water treatment system will be operated as much as possible with activities and planned downtimes. Additional continuous air monitoring could be provided if appropriate or required.

There are no compliance issues, major permit conditions, or unusual problems associated with this project as of July 1997.

Compiled by: Waste Management Federal Services of Hanford, Inc.

Date: July 31, 1997 for Fluor Daniel Hanford, Inc. 
DOE Operations Office: Richland

DOE Facility: Hanford Site

Existing Permit ( ) $\quad$ Renewal ( ) New Permit (X)

Permit Type: National Emission Standards for Hazardous Air Pollutants (NESHAPs) 40 CFR 61, Subpart H

Permitting Agency: U.S. Environmental Protection Agency, Region 10

Permit Number: EPA Letter dated January 7, 1997

Permitted Unit: 105-K East Basin Hydrolasing

Issuance Date: January 7, 1997

Expiration Date: N/A

Need for Headquarters' Action

(for permit renewals or new permits)

\section{Yes ( ) No (X)}

If yes; HQ Program Element

Brief Summary of Relevant Information (major permit conditions, status of compliance or unusual problems):

The approval of this application allows removal of some quantities of radioactively contaminated building structure from the Corridor 7 area to increase operating area in the basin and allow improved equipment and personnel movement. The approval also allows for the internal decontamination of existing piping in the basin water treatment system. Approximately 1500 feet of carbon steel piping and 60 feet of plastic piping will be cleaned.

There are no compliance issues, major permit conditions, or unusual problems associated with this project as of July 1997.

Compiled by: Waste Management Federal Services of Hanford, Inc.

Date: July 31, 1997 for Fluor Daniel Hanford, Inc. 
DOE Operations Office: Richland

DOE Facility: Hanford Site

Existing Permit ( ) Renewal ( ) New Permit (X)

Permit Type: Radiological Air Emissions Program Notice of Construction - WAC 246-247

Permitting Agency: Washington State Department of Health

Permit Number: Routine Technical Assistance Meeting, November 12, 1996

Permitted Unit: 105-K West Basin Corridor Modification

Issuance Date: November 12, 1996

Expiration Date: N/A

Need for Headquarters' Action

Yes ( ) No (X)

(for permit renewals or new permits)

If yes, HQ Program Element

Brief Summary of Relevant Information (major permit conditions, status of compliance or unusual problems):

Approval of this Notice of Construction is for corridor modification activities similar to those described in a previously approved Notice of Construction for 105-K East Basin Debris Removal. Additional health-physics-technician monitoring may be required during the 105-K West Basin Corridor Modification.

There are no compliance issues, major permit conditions, or unusual problems associated with this project as of July 1997.

Compiled by: Waste Management Federal Services of Hanford, Inc.

Date: July 31, 1997 for Fluor Daniel Hanford, Inc. 
DOE Operations Office: Richland

DOE Facility: Hanford Site

Existing Permit ( ) Renewal ( ) N New Permit (X)

Permit Type: Radiological Air Emissions Program Notice of Construction - WAC 246-247

Permitting Agency: Washington State Department of Health

Permit Number: Routine Technical Assistance Meeting, January 14, 1997

Permitted Unit: 105-K West Basin Sludge Pumping from the South Loadout Pit

Issuance Date: January 14, 1997

Expiration Date: N/A

Need for Headquarters' Action

(for permit renewals or new permits)

\section{Yes ( ) No (X)}

If yes, HQ Program Element

Brief Summary of Relevant Information (major permit conditions, status of compliance or unusual problems):

Approval of this Notice of Construction provides for the pumping of the 105-K West Basin sludge from the south loadout pit and depositing the sludge in an underwater accumulation area. Movement and accumulation of sludge has been previously demonstrated at the 105-K East Basin during barrier door installation as well as other cleanup actions. The sludge being pumped typically consists of dirt and other materials that settle out of the basin water including some corrosion products from fuel, structures, or equipment that is or has been in the basin.

There are no compliance issues, major permit conditions, or unusual problems associated with this project as of July 1997.

Compiled by: Waste Management Federal Services of Hanford, Inc.

Date: July 31, 1997 for Fluor Daniel Hanford, Inc. 
DOE Operations Office: Richland

DOE Facility: Hanford Site

Existing Permit ( ) Renewal ( ) New Permit (X)

Permit Type: Radiological Air Emissions Program Notice of Construction - WAC 246-247

Permitting Agency: Washington State Department of Heaith

Permit Number: Routine Technical Assistance Meeting Minutes dated September 10, 1996

Permitted Unit: 105-K West Demolition Activities

Issuance Date: September 10, 1996

Expiration Date: N/A

Need for Headquarters' Action

(for permit renewals or new permits)
Yes ( ) No (X)

If yes, HQ Program Element

Brief Summary of Relevant Information (major permit conditions, status of compliance or unusual problems):

Approval of this Notice of Construction covers the removal of substantial quantities of contaminated piping and structural steel from the transfer area. Other items such as electrical conduit, cabling, stairs, and space heaters also could be included.

There are no compliance issues, major permit conditions, or unusual problems associated with this project as of July 1997.

Compiled by: Waste Management Federal Services of Hanford, Inc.

Date: July 31,1997 for Fluor Daniel Hanford, Inc. 
DOE Operations Office: Richland

DOE Facility: Hanford Site

Existing Permit ( ) Renewal ( ) New Permit (X)

Permit Type: Notice of Construction for:

General Regulations for Air Pollution Sources - WAC 173-400

Controls for New Sources of Toxic Air Pollutants - WAC 173-460

Permitting Agency: Washington State Department of Ecology

Permit Number: NWP-96-1

Permitted Unit: 200 Area Diesel Generators

Issuance Date: April 30, 1996

Expiration Date: N/A

Need for Headquarters' Action

(for permit renewals or new permits)

Yes ( ) No (X)

If yes, HQ Program Element

Brief Summary of Relevant Information (major permit conditions, status of compliance or unusual problems):

Approval of this Notice of Construction allows construction and operation of two emergency diesel generators designed to provide emergency power for the 200 Areas fire protection system. A major permit condition includes limits on hours of operation and emission rates. During the period covered by this Status Report, the 200 Areas diesel generators operated with no compliance issues.

Compiled by: Waste Management Federal Services of Hanford, Inc.

Date: July 31, 1997 for Fluor Daniel Hanford, Inc. 
DOE Operations Office: Richland

DOE Facility: Hanford Site

Existing Permit ( ) Renewal ( ) New Permit (X)

Permit Type: National Emission Standards for Hazardous Air Pollutants (NESHAPs) 40 CFR 61, Subpart H

Permitting Agency: U.S. Environmental Protection Agency, Region 10

Permit Number: $\quad$ N/A

Permitted Unit: 200 Area Effluent Treatment Facility

Issuance Date: July 3, 1997

Expiration Date: N/A

Need for Headquarters' Action

(for permit renewals or new permits)

Yes ( ) No (X)

If yes, HQ Program Element

Brief Summary of Relevant Information (major permit conditions, status of compliance or unusual problems):

Approval of this application for modification to increase air emissions allows an increased potentialto-emit from the 200 Area Effluent Treatment Facility load-in station or the Liquid Effluent Retention Facility. The calculated abated offsite dose is $.025 \mathrm{mrem} / \mathrm{hr}$.

During the period covered by this Status Report, these activities proceeded with no compliance issues.

Compiled by: Waste Management Federal Services of Hanford, Inc.

Date: July 31, 1997 for Fluor Daniel Hanford, Inc. 
DOE Operations Office: Richland

DOE Facility: Hanford Site

Existing Permit ( ) Renewal ( ) New Permit (X)

Permit Type: Notice of Construction - Nonradioactive Air Emissions Modification

Permitting Agency: Washington State Department of Ecology

Permit Number: $90 \mathrm{NW}-1-301$

Permitted Unit: 200 Area Effluent Treatment Facility and the Liquid Effluent Retention Facility

Issuance Date: October 16, 1996

Expiration Date: N/A

Need for Headquarters' Action

Yes ( ) No (X)

(for permit renewals or new permits)

If yes, HQ Program Element

Brief Summary of Relevant Information (major permit conditions, status of compliance or unusual problems):

Approval of this Notice of Construction was granted to expand the original approval to include influent streams from 200-UP-1 groundwater and N Basin water.

During the period covered by this Status Report, the 200 Area ETF operated with no compliance issues.

Compiled by: Waste Management Federal Services of Hanford, Inc.

Date: July 31, 1997 for Fluor Daniel Hanford, Inc. 
DOE Operations Office: Richland

DOE Facility: Hanford Site

Existing Permit ( ) Renewal ( ) New Permit (X)

Permit Type: WAC-246-247

Permitting Agency: Washington State Department of Health

Permit Number: Routine Technical Assistance Meeting

Permitted Unit: 200 Area Effluent Treatment Facility Load-In Station and Liquid Effluent Retention Facility

Issuance Date: January 1997

Expiration Date: N/A

Need for Headquarters' Action

(for permit renewals or new permits)
Yes () No(X)

If yes, HQ Program Element

Brief Summary of Relevant Information (major permit conditions, status of compliance or unusual problems):

Approval of this Notice of Construction allows an increased potential-to-emit from the 200 Area Effluent Treatment Facility Load-In Station or the Liquid Effluent Retention Facility. The abated offsite dose was calculated at $.025 \mathrm{mrem} / \mathrm{hr}$.

During the period covered by this Status Report, these activities proceeded with no compliance issues.

Compiled by: Waste Management Federal Services of Hanford, Inc.

Date: July 31,1997 for Fluor Daniel Hanford, Inc. 
DOE Operations Office: Richland

DOE Facility: Hanford Site

Existing Permit (X) Renewal ( ) New Permit ( )

Permit Type: Radioactive Air Emissions Program Notice of Construction - WAC 246-247.

Permitting Agency: Washington State Department of Health

Permit Number: AIR 91-NOV1

Permitted Unit: 219-S Sample Gallery to 204-AR Waste Unloading Station Waste Transfers

Issuance Date: November 12, 1991

Expiration Date: N/A

Need for Headquarters' Action

(for permit renewais or new permits)
Yes ( ) No (X)

If yes, HQ Program Element

Brief Summary of Relevant Information (major permit conditions, status of compliance or unusual problems):

Approval of this Notice of Construction allows construction for waste transfers from the 219-S Sample Gallery to the 204-AR Waste Unloading Station in accordance with descriptions contained in the application. Routine transfers of waste from the 219-S Sample Gallery in the 222-S Laboratory Complex, located in the 200 West Area, to the 204-AR Waste Unloading Station, located in the 200 East Area, are required to remove waste from the 222-S Laboratory Complex to the Double-Shell Tank System.

Compiled by: Waste Management Federal Services of Hanford, Inc.

Date: July 31, 1997 for Fluor Daniel Hanford, Inc. 
DOE Operations Office: Richland

DOE Facility: Hanford Site

Existing Permit ( ) Renewal ( ) New Permit (X)

Permit Type: Radioactive Air Emissions Notice of Construction - WAC 246-247

Permitting Agency: Washington State Department of Health

Permit Number: Routine Technical Assistance Meeting (12/10/96)

Permitted Unit: 222-S Laboratory Complex

Issuance Date: December 19, 1996

Expiration Date: N/A

Need for Headquarters' Action

(for permit renewalls or new permits)

$$
\text { Yes ( ) No (X) }
$$

If yes, HQ Program Element

Brief Summary of Relevant Information (major permit conditions, status of compliance or unusual problems):

This Notice of Construction supports Project W-087. Project W-087 provides new double wall piping and necessary tie-ins within the 222-S Laboratory Facility, within the adjacent 219-S Facility, and between 219-S and 244-S Catch Station at 200 West Tank Farms. It also provides for leak detection and flow monitoring at various locations and removes old piping, as necessary, for installation of new piping and equipment.

The magnitude of this activity is small and it will be administratively controlled with the use of beta continuous air monitoring to $0.01 \mathrm{mrem}$ effective dose equivalent offsite dose or less.

Compiled by: Waste Management Federal Services of Hanford, Inc. Date: July 31, 1997 for Fluor Daniel Hanford, Inc. 
DOE Operations Office: Richland

DOE Facility: Hanford Site

Existing Permit ( )

Renewal ( )

New Permit (X)

Permit Type: National Emission Standards for Hazardous Air Pollutants (NESHAPs) 40 CFR 61, Subpart H

Permitting Agency: U.S. Environmental Protection Agency, Region 10

Permit Number: N/A

Permitted Unit: 222-S Laboratory Complex

Issuance Date: January 9, 1997

Expiration Date: N/A

Need for Headquarters' Action

(for permit renewals or new permits)
Yes ( ) No (X)

If yes, HQ Program Element

Brief Summary of Relevant Information (major permit conditions, status of compliance or unusual problems):

This application supports Project. W-087. Project W-087 provides new double wall piping and necessary tie-ins within the 222-S Laboratory Complex, within the adjacent 219-S Facility, and between 219-S and 244-S Catch Station at 200 West Tank Farms. Also provided is leak detection and flow monitoring at various locations and removed of old piping, as necessary, for installation of new piping and equipment.

This activity is small and will be controlled administratively with the use of beta continuous air monitoring to $0.01 \mathrm{mrem}$ effective dose equivalent offsite dose or less.

Compiled by: Waste Management Federal Services of Hanford, Inc. Date: July 31, 1997 for Fluor Daniel Hanford, Inc. 
DOE Operations Office: Richland

DOE Facility: Hanford Site

Existing Permit ( ) Renewal ( ) New Permit (X)

Permit Type: Radioactive Air Emissions Notice of Construction - WAC 246-247

Permitting Agency: Washington State Department of Health

Permit Number: Special request

Permitted Unit: 222-S Laboratory Complex

Issuance Date: May 28, 1997

Expiration Date: N/A

Need for Headquarters' Action

(for permit renewals or new permits)

\section{Yes ( ) No ( $\mathrm{X}$ )}

If yes, HQ Program Element

Brief Summary of Relevant Information (major permit conditions, status of compliance or unusual problems):

The approval of this Notice of Construction allowed a change in the administrative control mechanism from beta continuous air monitoring to the daily analyses of continuous air samples taken in the work area.

Compiled by: Waste Management Federal Services of Hanford, Inc.

Date: July 31, 1997 for Fluor Daniel Hanford, Inc. 
DOE Operations Office: Richland

DOE Facility: Hanford Site

Existing Permit ( ) Renewal ( ) . New Permit (X)

Permit Type: National Emission Standards for Hazardous Air Pollutants (NESHAPs) 40 CFR 61, Subpart H

Permitting Agency: U.S. Environmental Protection Agency, Region 10

Permit Number: N/A

Permitted Unit: 222-S Laboratory Complex

Issuance Date: July 1, 1997

Expiration Date: N/A

Need for Headquarters' Action

(for permit renewals or new permits)

Yes ( ) No (X)

If yes, HQ Program Element

Brief Summary of Relevant Information (major permit conditions, status of compliance or unusual problems):

The approval of this application allowed a change in the administrative control mechanism from beta continuous air monitoring to the daily analyses of continuous air samples taken in the work areas.

Compiled by: Waste Management Federal Services of Hanford, Inc. Date: July 31, 1997 for Fluor Daniel Hanford, Inc. 
DOE Operations Office: Richland

DOE Facility: Hanford Site

Existing Permit (X)

Renewal ( )

New Permit ( )

Permit Type: Radioactive Air Emissions Program Notice of Construction - WAC 246-247

Permitting Agency: Washington State Department of Health

Permit Number: Routine Technical Assistance Meeting

Permitted Unit: $231-Z$ Building Deactivation Activities

Issuance Date: August 1995

Expiration Date: NA

Need for Headquarters' Action

(for permit renewals or new permits)

Yes ( ) No (X)

If yes, HQ Program Element

Brief Summary of Relevant Information (major permit conditions, status of compliance or unusual problems):

Approval of this Notice of Construction was granted, subject to the $231-Z$ Building deactivation activities, for the removal of loose equipment and packaging/removal for disposal.

During the period covered by this Status Report, these deactivation activities proceeded with no compliance issues.

Compiled by: Waste Management Federal Services of Hanford, Inc. Date: July 31, 1997 for Fluor Daniel Hanford, Inc. 
DOE Operations Office: Richland

DOE Facility: Hanford Site

Existing Permit (X) $\quad$ Renewal ( ) New Permit ( )

Permit Type: Radioactive Air Emissions Program Notice of Construction - WAC 246-247

Permitting Agency: Washington State Department of Health

Permit Number: AIR-95-106

Permitted Unit: 232-Z Building Modification

Issuance Date: January 24, 1995

Expiration Date: N/A

Need for Headquarters' Action

(for permit renewals or new permits)
Yes ( ) No (X)

If yes, HQ Program Element

Brief Summary of Relevant Information (major permit conditions, status of compliance or unusual problems):

Approval of this Notice of Construction allowed for the cleanup and removal of contaminated portions of the 232-Z Building in accordance with the conditions and descriptions contained in the Notice of Construction. The main purpose of the modification was to reduce the potential for a significant release in case of a damaging seismic event. A secondary benefit was reduced exposure to personnel during routine work and future decontamination and demolition activities. The first cleanup campaign was approved on February 28, 1994 (AIR-94-217), and completed in July 1994. Additional cleanup was required and a modification to the application was resubmitted with approval received on January 24, 1995.

During the period covered by this Status Report, the 232-Z Building modifications proceeded with no compliance issues.

Compiled by: Waste Management Federal Services of Hanford, Inc.

Date: July 31, 1997

for Fluor Daniel Hanford, Inc. 
DOE Operations Office: Richland

DOE Facility: Hanford Site

Existing Permit (X) Renewal ( ) New Permit ( )

Permit Type: National Emission Standard for Hazardous Air Pollutants (NESHAPs) 40 CFR 61, Subpart H

Permitting Agency: U.S. Environmental Protection Agency, Region 10

Permit Number: N/A

Permitted Unit: 232-Z Building Modification

Issuance Date: February 1, 1995

Expiration Date: N/A

Need for Headquarters' Action

(for permit renewals or new permits)
Yes ( ) No ( $X)$

If yes, HQ Program Element

Brief Summary of Relevant Information (major permit conditions, status of compliance or unusual problems):

Approval of this application allowed for the cleanup and removal of contaminated portions of the 232-Z Building in accordance with the conditions and descriptions contained in the application. The main purpose of the modification was to reduce the potential for a significant release in case of a damaging seismic event. A secondary benefit was reduced exposure to personnel during routine work and future decontamination and demolition activities. The first cleanup campaign was approved on March 3, 1994, and completed in July 1994. Additional cleanup was required so a modification to the application was resubmitted and approval was granted on February 1, 1995.

During the period covered by this Status Report, the $232-Z$ Building modifications proceeded with no compliance issues.

Compiled by: Waste Management Federal Services of Hanford, Inc.

Date: July 31, 1997 for Fluor Daniel Hanford, Inc. 
DOE Operations Office: Richland

DOE Facility: Hanford Site

Existing Permit ( ) Renewal ( ) New Permit (X)

Permit Type: Radioactive Air Emissions Program Notice of Construction - WAC 246-247

Permitting Agency: Washington State Department of Health

Permit Number: Routine Technical Assistance Meeting

Permitted Unit: $234-5-Z$ Muffle Furnaces

Issuance Date: August 1995

Expiration Date: NA

Need for Headquarters' Action

(for permit renewals or new permits)
Yes ( ) No (X)

If yes, HQ Program Element

Brief Summary of Relevant Information (major permit conditions, status of compliance or unusual problems):

Approval of this Notice of Construction allows the installation and operation of two additional muffle furnaces at 234-5-Z. The startup of two muffle furnaces in 1994 showed no increase in measurable emissions. No measurable increase is expected due to startup of six additional furnaces (three in each of two gloveboxes).

During the period covered by this Status Report, the 234-5-Z Muffle Furnaces operated with no compliance issues.

Compiled by: Waste Management Federal Services of Hanford, Inc. for Fluor Daniel Hanford, Inc.

Date: July 31, 1997 
DOE Operations Office: Richland

DOE Facility: Hanford Site

Existing Permit (X) Renewal ( ) New Permit ( )

Permit Type: Radioactive Air Emissions Program Notice of Construction - WAC 246-247.

Permitting Agency: Washington State Department of Health

Permit Number: AIR 96-607

Permitted Unit: 241-A-101 Tank Portable Exhauster

Issuance Date: June 17, 1996

Expiration Date: N/A

Need for Headquarters' Action

(for permit renewals or new permits)

Yes ( ) No ( $\mathrm{X}$ )

If yes, HQ Program Element

Brief Summary of Releyant Information (major permit conditions, status of compliance or unusual problems):

Approval of this Notice of Construction allows active ventilation, via the use of a portable exhauster, on the 241-A-101 tank during salt well pumping and other routine activities performed in accordance with descriptions contained in the Notice of Construction.

During the period covered by this Status Report, the portable exhauster activity proceeded with no compliance issues.

Compiled by: Waste Management Federal Services of Hanford, Inc.

Date: July 31, 1997 for Fluor Daniel Hanford, Inc. 
DOE Operations Office: Richland

DOE Facility: Hanford Site

Existing Permit (X) Renewal ( ) New Permit ( )

Permit Type: Notice of Construction for:

General Regulations for Air Pollution Sources - WAC 173-400

Controls for New Sources of Toxic Air Pollutants - WAC 173-460

Permitting Agency: Washington State Department of Ecology

Permit Number: 96-NM-086

Permitted Unit: 241-A-101 Tank Portable Exhauster

Issuance Date: June 24, 1996

Expiration Date: N/A

Need for Headquarters' Action

(for permit renewals or new permits)

Yes ( ) No (X)

If yes, HQ Program Element

Brief Summary of Relevant Information (major permit conditions, status of compliance or unusual problems):

Approval of this Notice of Construction allows active ventilation, via the use of a portable exhauster, on the 241-A-101 tank during salt well pumping and other routine activities performed at the tank. Major permit conditions include limits on volatile organic carbon emission rates and opacity.

During the period covered by this Status Report, the portable exhauster activity proceeded with no compliance issues.

Compiled by: Waste Management Federal Services of Hanford, Inc.

Date: July 31,1997 for Fluor Daniel Hanford, Inc. 
DOE Operations Office: Richland

DOE Facility: Hanford Site

Existing Permit (X) Renewal ( ) New Permit ( )

Permit Type: National Emission Standard for Hazardous Air Pollutants (NESHAPs) 40 CFR 61, Subpart H

Permitting Agency: U.S. Environmental Protection Agency, Region 10

Permit Number: N/A

Permitted Unit: 241-A-101 Tank Portable Exhauster

Issuance Date: July 2, 1996

Expiration Date: N/A

Need for Headquarters' Action

(for permit renewals or new permits)
Yes (.) No (X)

If yes, HQ Program Element

Brief Summary of Relevant Information (major permit conditions, status of compliance or unusual problems):

Approval of this application allows for the active ventilation, via the use of a portable exhauster, on the 241-A-101 tank during salt well pumping and other routine activities performed in accordance with descriptions contained in the application.

During the period covered by this Status Report, the portable exhauster activity proceeded with no compliance issues.

Compiled by: Waste Management Federal Services of Hanford, Inc. Date: July 31, 1997 for Fluor Daniel Hanford, Inc. 
DOE Operations Office: Richland

DOE Facility: Hanford Site

Existing Permit (X) Renewal ( ) New Permit ( )

Permit Type: Radioactive Air Emissions Program Notice of Construction - WAC 246-247

Permitting Agency: Washington State Department of Health

Permit Number: AIR 94-502, AIR 96-702, AIR 96-705

Permitted Unit: 241-AZ-101 Tank Waste Retrieval and 241-AY/241-AZ Tank Farms Ventilation Upgrades, Project W-151 and Project W-030

Issuance Date: May 5, 1994, June 5, 1996, July 10, 1996, July 1 1, 1996

Expiration Date: N/A

Need for Headquarters' Action

(for permit renewals or new permits)
Yes ( ) No (X)

If yes, HQ Program Element

Brief Summary of Relevant Information (major permit conditions, status of compliance or unusual problems):

Approval of this Notice of Construction allows the installation and operation of mixer pumps in the 241-AZ-101 tank (an existing double-shell tank) using approved radionuclide air emissions control equipment in accordance with descriptions contained in the Notice of Construction. Project W-151 demonstrates techniques to be used for future retrieval activities. Project W-030 provides ventilation upgrades in the 24l-AY/241-AZ Tank Farms. Both tank farms are ventilated through the same ventilation system. During the period covered by this Status Report, these projects proceeded with no compliance issues.

A request to remove the continuous monitoring for iodine and tritium, as specified in the Notice of Construction, was approved on July 10, 1996.

A notification of emission changes for the planned testing of the mixer pumps before the completion of the ventilation upgrades was approved on July 11,1997 , with the condition that the new ventilation be operational in 4 months. Requests to extend the 4-month deadline out another 4 months were made and granted on October 8, 1996, November 12, 1996, and February 11, 1997. The extensions were requested because testing of the mixer pumps was delayed. The February 1997 approval granted extension until November 11, 1997.

Use of a vacuum loader for excavation activities as part of the $W-030$ project was approved on June 5, 1996.

Compiled by: Waste Management Federal Services of Hanford, Inc. Date: July 31, 1997 for Fluor Daniel Hanford, Inc. 
DOE Operations Office: Richland

DOE Facility: Hanford Site

Existing Permit ( $\mathrm{X}$ - Renewal ( ) New Permit ( )

Permit Type: National Emission Standard for Hazardous Air Pollutants (NESHAPs) 40 CFR 61, Subpart H

Permitting Agency: U.S. Environmental Protection Agency, Region 10

Permit Number: N/A

Permitted Unit: 241-AZ-101 Tank Waste Retrieval and 241-AY/241-AZ Tank Farms Ventilation Upgrades, Project W-151 and Project W-030

Issuance Date: March 15, 1994, July 3, 1996, September 3, 1996, March 20, 1997

Expiration Date: N/A

Need for Headquarters' Action

(for permit renewals or new permits)
Yes ( ) No (X)

If yes, HQ Program Element

Brief Summary of Relevant Information (major permit conditions, status of compliance or unusual problems):

Approval of this application allows the installation and operation of mixer pumps in the 241-AZ-101 tank (an existing double-shell tank) using approved radionuclide air emissions control equipment in accordance with descriptions contained in the application. Project W-151 demonstrates techniques to be used for future retrieval activities. Project $\mathrm{W}-030$ provides ventilation upgrades in the 241-AY/241-AZ Tank Farms. Both tank farms are ventilated through the same ventilation system. During the period covered by this Status Report, these projects proceeded with no compliance issues.

A request to remove the continuous monitoring for iodine and tritium, as specified in the Notice of Construction, was approved on September 3, 1996. A notification of emission changes for the planned testing of the mixer pumps before the completion of the ventilation upgrades was approved on March 20, 1997.

Use of a vacuum loader for excavation activities as part of Project W-030 was approved on July 3, 1996.

Compiled by: Waste Management Federal Services of Hanford, Inc. for Fluor Daniel Hanford, Inc.

Date: July 31, 1997 
DOE Operations Office: Richland

DOE Facility: Hanford Site

Existing Permit (X) Nenewal ( ) Nermit ( )

Permit Type: Notice of Construction for:

General Regulations for Air Pollution Sources - WAC 173-400

Controls for New Sources of Toxic Air Pollutants - WAC 173-460

Permitting Agency: Washington State Department of Ecology

Permit Number: NOC-94-07

Permitted Unit: 241-AZ-101 Tank Waste Retrieval and 241-AY/241-AZ Tank Farms Ventilation Upgrades, Project W-151 and Project W-030

Issuance Date: August 26, 1994

Expiration Date: N/A

Need for Headquarters' Action

(for permit renewals or new permits)
Yes ( ) No (X)

If yes, HQ Program Element

Brief Summary of Relevant Information (major permit conditions, status of compliance or unusual problems):

Approval of this Notice of Construction allows the installation and operation of mixer pumps in the 241-AZ-101 tank (an existing double-shell tank) using approved radionuclide air emissions control equipment in accordance with descriptions contained in the Notice of Construction. Project W-151 demonstrates techniques to be used for future retrieval activities. Project W-030 provides ventilation upgrades in the 241-AY/24I-AZ Tank Farms. Both tank farms are ventilated through the same ventilation system. During the period covered by this Status Report, these projects proceeded with no compliance issues.

A notification of emission changes for the planned testing of the mixer pumps before the completion of the ventilation upgrades was submitted on July 18, 1996. Ecology requested more information, which was prepared and submitted on October 1, 1996. Following discussions with Ecology, a request for approval to modify the volatile organic compound limit in the original permit, to waiver the volatile organic compound and ammonia monitoring requirement during operational testing of the pumps, and to use a different measurement method accuracy than the referenced EPA method was submitted on January 30,1997. No approval has been received as of this report date.

Compiled by: Waste Management Federal Services of Hanford, Inc. Date: July 31, 1997 for Fluor Daniel Hanford, Inc. 
DOE Operations Office: Richland

DOE Facility: Hanford Site

Existing Permit (X) Renewal ( ) New Permit ( )

Permit Type: Radioactive Air Emissions Program Notice of Construction - WAC 246-247

Permitting Agency: Washington State Department of Health

Permit Number: AIR 95-712

Permitted Unit: 241-C-106 Tank Sluicing, Project W-320

Issuance Date: July 31, 1995

Expiration Date: N/A

Need for Headquarters' Action

(for permit renewals or new permits)
Yes ( ) No (X)

If yes, HQ Program Element

Brief Summary of Relevant Information (major permit conditions, status of compliance or unusual problems):

Approval of this Notice of Construction allows construction and operation of the 241-C-106 tank waste retrieval system in accordance with descriptions contained in the Notice of Construction. The 241-C-106 tank is a high-heat watchlist single-shell tank. This high-heat waste tank requires the addition of water to cool the tank waste. Retrieval of the waste eliminates the need to add water to the tank. Two phases of permitting were pursued. Phase I approval, received from the Department of Health on February 28, 1994 (AIR-94-214), did not involve radioactive air emissions. The remaining Phase II activities generate radioactive air emissions.

During the period covered by this Status Report, this project operated with no compliance issues.

Compiled by: Waste Management Federal Services of Hanford, Inc.

Date: July 31, 1997

for Fluor Daniel Hanford, Inc. 
DOE Operations Office: Richland

DOE Facility: Hanford Site

Existing Permit (X) Renewal ( ) $\quad$ New Permit ( )

Permit Type: National Emission Standard for Hazardous Air Pollutants (NESHAPs) 40 CFR 61, Subpart H

Permitting Agency: U.S. Environmental Protection Agency, Region 10

Permit Number: I94-RPS-254

Permitted Unit: 241-C-106 Tank Sluicing, Phase II, Project W-320

Issuance Date: February 23, 1994

Expiration Date: N/A

Need for Headquarters' Action

(for permit renewals or new permits)
Yes ( ) No (X)

If yes, HQ Program Element

Brief Summary of Relevant Information (major permit conditions, status of compliance or unusual problems):

Approval of this application allows construction and operation of the 241-C-106 tank waste retrieval system in accordance with descriptions contained in the application. The 241-C-106 tank is a high-heat watchlist single-shell tank. This high-heat waste tank requires the addition of water to cool the tank waste. Retrieval of the waste eliminates the need to add water to the tank.

During the period covered by this Status Report, this project operated with no compliance issues.

Compiled by: Waste Management Federal Services of Hanford, Inc. Date: July 31, 1997 for Fluor Daniel Hanford, Inc. 
DOE Operations Office: Richland

DOE Facility: Hanford Site

Existing Permit (X) Renewal ( ) New Permit ( )

Permit Type: Notice of Construction for:

General Regulations for Air Pollution Sources - WAC 173-400

Controls for New Sources of Toxic Air Pollutants - WAC 173-460

Permitting Agency; Washington State Department of Ecology

Permit Number: NWP 95(7) C-106

Permitted Unit: 241-C-106 Tank Sluicing, Project W-320

Issuance Date: October 6, 1995

Expiration Date: N/A

Need for Headquarters' Action

(for permit renewals or new permits)
Yes ( ) No (X)

If yes, HQ Program Element

Brief Summary of Relevant Information (major permit conditions, status of compliance or unusual problems):

Approval of this Notice of Construction allows construction and operation of the 241-C-106 tank waste retrieval system using approved nonradionuclide air emissions control equipment. The 241-C-106 tank is a high-heat watchlist single-shell tank. This high-heat waste tank requires the addition of water to cool the tank waste. Retrieval of the waste eliminates the need to add water to the tank. Two phases of permitting were pursued. Phase I did not involve nonradioactive air emissions, and Ecology indicated that written approval for Phase I was not required. The major permit conditions include initial compliance demonstration for volatile organic compounds and no visible emissions with respect to particulate matter less than 10 microns criteria pollutant.

During the period covered by this Status Report, this project operated with no compliance issues.

Compiled by: Waste Management Federal Services of Hanford, Inc.

Date: July 31,1997 for Fluor Daniel Hanford, Inc. 
DOE Operations Office: Richland

DOE Facility: Hanford Site

Existing Permit (X) Renewal ( ) New Permit ( )

Permit Type: Radioactive Air Emissions Program Notice of Construction - WAC 246-247

Permitting Agency: Washington State Department of Health

Permit Number: AIR 95-203

Permitted Unit: 241-SY-101 Tank Mixer Pump Replacement

Issuance Date: February 21, 1995

Expiration Date: N/A

Need for Headquarters' Action

(for permit renewals or new permits)
Yes ( ) No (X)

If yes, HQ Program Element

Brief Summary of Relevant Information (major permit conditions, status of compliance or unusual problems):

Approval of this Notice of Construction allows replacement of the present 241-SY-101 mixer pump, if the current pump fails, in accordance with descriptions contained in the Notice of Construction. The mixer pump is designed to mitigate flammable gas buildup in the 241-SY-101 tank.

During the period covered by this Status Report, the 241-SY-101 mixer pump operated with no compliance issues.

Compiled by: Waste Management Federal Services of Hanford, Inc.

Date: July 31, 1997 for Fluor Daniel Hanford, Inc. 
DOE Operations Office: Richland

DOE Facility: Hanford Site

Existing Permit (X) Renewal ( ) New Permit ( )

Permit Type: National Emission Standard for Hazardous Air Pollutants (NESHAPs) 40 CFR 61, Subpart H

Permitting Agency: U.S. Environmental Protection Agency, Region 10

Permit Number: N/A

Permitted Unit: 241-SY-101 Tank Mixer Pump Replacement

Issuance Date: February 14, 1995

Expiration Date: N/A

Need for Headquarters' Action

(for permit renewals or new permits)
Yes ( ) No (X)

If yes, HQ Program Element

Brief Summary of Relevant Information (major permit conditions, status of compliance or unusual problems):

Approval of this application allows replacement of the present 241-SY-101 mixer pump, if the current pump fails, in accordance with descriptions contained in the application. The mixer pump is designed to mitigate flammable gas buildup in the 241-SY-101 tank.

During the period covered by this Status Report; the 241-SY-101 mixer pump operated with no compliance issues.

Compiled by: Waste Management Federal Services of Hanford, Inc.

Date: July 31, 1997 for Fluor Daniel Hanford, Inc. 
DOE Operations Office: Richland

DOE Facility: Hanford Site

Existing Permit ( ) Renewal ( ) New Permit (X)

Permit Type: National Emission Standard for Hazardous Air Pollutants (NESHAPs) 40 CFR 61, Subpart H

Permitting Agency: U.S. Environmental Protection Agency, Region 10

Permit Number: N/A

Permitted Unit: 244-AR Vault Portable Exhauster

Issuance Date: TBD

Expiration Date: TBD

Need for Headquarters' Action

(for permit renewals or new permits)

\author{
Yes ( ) No (X) \\ If yes, HQ Program Element
}

Brief Summary of Relevant Information (major permit conditions, status of compliance or unusual problems):

Approval of this application will allow use of a portable exhauster in the 244-AR Vault during air jetting of accumulated liquids from the cell sumps into the tanks and to make transfers among the tanks within the vault using radionuclide air emissions control equipment in accordance with descriptions contained in this application. The vault has been inactive since 1978 with the ventilation system inactive since 1993. Rain water and/or snow melt has accumulated in the sumps since cessation of operations. Active ventilation is required for air jetting operations; therefore, a portable exhauster will be used while removing the water from the sumps.

Compiled by: Waste Management Federal Services of Hanford, Inc.

Date: July 31, 1997

for Fluor Daniel Hanford, Inc. 
DOE Operations Office: Richland

DOE Facility: Hanford Site

Existing Permit ( ) Renewal ( ) New Permit (X)

Permit Type: Radioactive Air Emission Program Notice of Construction - WAC 246-247

Permitting Agency: Washington State Department of Health

Permit Number:

Permitted Unit: 244-AR Vault Portable Exhauster

Issuance Date: TBD

Expiration Date: TBD

Need for Headquarters' Action

(for permit renewals or new permits)

Yes ( ) No $(X)$

If yes, HQ Program Element

Brief Summary of Relevant Information (major permit conditions, status of compliance or unusual problems):

Approval of this Notice of Construction will allow use of a portable exhauster in the 244-AR Vault during air jetting of accumulated liquids from the cell sumps into the tanks and to make transfers among the tanks within the vault using radionuclide air emissions control equipment in accordance with descriptions contained in the Notice of Construction. The vault has been inactive since 1978 with the ventilation system inactive since 1993. Rain water and/or snow melt has accumulated in the sumps since cessation of operations. Active ventilation is required for air jetting operations; therefore, a portable exhauster will be used while removing the water from the sumps.

Compiled by: Waste Management Federal Services of Hanford, Inc. Date: July 31, 1997 for Fluor Daniel Hanford, Inc. 
DOE Operations Office: Richland

DOE Facility: Hanford Site

Existing Permit (X) Renewal ( ) New Permit ( )

Permit Type: Radioactive Air Emissions Program Notice of Construction - WAC 246-247

Permitting Agency: Washington State Department of Health

Permit Number: AIR 94-913

Permitted Unit: 244-CR Vault Double-Contained Receiver Tank

Issuance Date: September 15, 1994

Expiration Date: N/A

Need for Headquarters' Action

(for permit renewals or new permits)
Yes ( ) No (X)

If yes, HQ Program Element

Brief Summary of Relevant Information (major permit conditions, status of compliance or unusual problems):

Approval of this Notice of Construction was granted subject to the 244-CR Vault double-contained receiver tank operating in accordance with descriptions contained in the Notice of Construction.

During the period covered by this Status Report, the 244-CR Vault double-contained receiver tank operated with no compliance issues.

Compiled by: Waste Management Federal Services of Hanford, Inc.

Date: July 31, 1997 for Fluor Daniel Hanford, Inc. 
DOE Operations Office: Richland

DOE Facility: Hanford Site

Existing Permit (X) Renewal ( ) New Permit ( )

Permit Type: Radioactive Air Emissions Program Notice of Construction — WAC 246-247

Permitting Agency: Washington State Department of Health

Permit Number: AIR 94-919, AIR 96-1110

Permitted Unit: 244-U Double-Contained Receiver Tank

Issuance Date: October 4, 1994; November 26, 1996

Expiration Date:

Need for Headquarters' Action

(for permit renewals or new permits)
Yes ( ) No (X)

If yes, HQ Program Element

Brief Summary of Relevant Information (major permit conditions, status of compliance or unusual problems):

Approval of this Notice of Construction allows operation of the 244-U double-contained receiver tank (DCRT) using radionuclide air emissions control equipment in accordance with descriptions contained in the Notice of Construction. The 244-U DCRT serves as the staging point for waste pumped from the 241-U single-shell tanks for subsequent transfer to double-shell tanks. Construction was completed in 1978; however, the 244-U DCRT has never been brought into operation.

A modification increasing the abated emissions, by taking credit for only one HEPA filter in the calculations, was approved on November 26, 1996. The modification was made because even though there are three consecutive HEPAs in the filter train, the filters only can be functionally tested as one.

Compiled by: Waste Management Federal Services of Hanford, Inc.

Date: July 31, 1997 for Fluor Daniel Hanford, Inc. 
DOE Operations Office: Richland

DOE Facility: Hanford Site

Existing Permit ( $\mathrm{X}$ ) Renewal ( ) New Permit ( )

Permit Type: National Emission Standard for Hazardous Air Pollutants (NESHAPs) 40 CFR 61, Subpart H

Permitting Agency: U.S. Environmental Protection Agency, Region 10

Permit Number: N/A

Permitted Unit: 244-U Double-Contained Receiver Tank

Issuance Date: October 6, 1994

Expiration Date:

Need for Headquarters' Action

(for permit renewals or new permits)
Yes ( ) No (X)

If yes, HQ Program Element

Brief Summary of Relevant Information (major permit conditions, status of compliance or unusual problems):

Approval of this application allows operation of the 244-U double-contained receiver $\operatorname{tank}$ (DCRT) using radionuclide air emissions control equipment in accordance with descriptions contained in the Notice of Construction. The 244-U DCRT serves as the staging point for waste pumped from the 241-U single-shell tanks for subsequent transfer to double-shell tanks. Construction was completed in 1978; however, the 244-U DCRT facility has never been brought into operation.

A modification increasing the abated emissions, by taking credit for only one HEPA filter in the calculations, was submitted on October 30,1996, and has not yet been approved. The modification was made because even though there are three consecutive HEPAs in the filter train, the filters only can be functionally tested as one.

Compiled by: Waste Management Federal Services of Hanford, Inc.

Date: July 31, 1997

for Fluor Daniel Hanford, Inc. 
DOE Operations Office: Richland

DOE Facility: Hanford Site

Existing Permit ( ) Renewal ( ) New Permit (X)

Permit Type: Radioactive Air Emissions Program Notice of Construction - WAC 246-247, 40 CFR 61

Permitting Agency: Washington State Department of Health,

U.S. Environmental Protection Agency

Permit Number:

Permitted Unit: 300 Area Fuel Supply Shutdown Facilities

Issuance Date: Washington State Department of Health: October 14, 1996

U.S. Environmental Protection Agency: October 3, 1996

Expiration Date: NA

Need for Headquarters' Action

(for permit renewals or new permits)

Yes ( ) No (X)

If yes, HQ Program Element

Brief Summary of Relevant Information (major permit conditions, status of compliance or unusual problems):

Approval of the Application to Construct (October 3, 1996) and the Notice of Construction (October 14, 1996) allows the decontamination of radiological materials from the 300 Area fuel supply shutdown facilities.

While performing radiological material decontamination activities, it was determined that the work could not be completed under the terms and conditions of the Notice of Construction. Consequently, a new Notice of Construction application was submitted to the Department of Health in July 1997. A response to the application is pending.

Compiled by: Waste Management Federal Services of Hanford, Inc. Date: July 31, 1997 for Fluor Daniel Hanford, Inc. 
DOE Operations Office: Richland

DOE Facility: Hanford Site

Existing Permit $(\mathrm{X})$

Renewal ( )

New Permit ( )

Permit Type: Radioactive Air Emissions Program Notice of Construction - WAC 246-247

Permitting Agency: Washington State Department of Health

Permit Number: AIR-95-811

Permitted Unit: $305-B$ Storage Facility

Issuance Date: August 25, 1995

Expiration Date: N/A

Need for Headquarters' Action

(for permit renewals or new permits)
Yes ( ) No (X)

If yes, HQ Program Element

Brief Summary of Relevant Information (major permit conditions, status of compliance or unusual problems):

Approval of this Notice of Construction allowed the construction of a fume hood in the 305-B Storage Facility for waste sampling and repackaging activities and approved the radionuclide air emissions control equipment. On August 25, 1995, an approval letter was received from the Department of Health. The construction of the fume hood in the 305-B Storage Facility is complete and operational.

Compiled by: Pacific Northwest National Laboratory

Date: July 31, 1997

Environmental Protection 
DOE Operations Office: Richland

DOE Facility: Hanford Site

Existing Permit (X) Renewal ( ) New Permit ( )

Permit Type: Radioactive Air Emissions Program Notice of Construction - WAC 246-247

Permitting Agency: Washington State Department of Health

Permit Number: Routine Technical Assistance Meeting

Permitted Unit: 313 Facility Uranium-Bearing System Removal

Issuance Date: November 1995

Expiration Date: NA

Need for Headquarters' Action

(for permit renewals or new permits)
Yes ( ) No ( $\mathrm{X}$ )

If yes, HQ Program Element

Brief Summary of Relevant Information. (major permit conditions, status of compliance or unusual problems):

Approval of this Notice of Construction allows the removal of residual uranium-bearing material from a system of tanks and valves in the 313 Building as a part of deactivation activities. While performing the uranium removal activities, it was determined that the work could not be completed under the terms and conditions of the Notice of Construction. Consequently, a new Notice of Construction application was submitted to the Department of Health in July 1997. A response to the application is pending.

Compiled by: Waste Management Federal Services of Hanford, Inc. Date: July 31, 1997 for Fluor Daniel Hanford, Inc. 
DOE Operations Office: Richland

DOE Facility: Hanford Site

Existing Permit (X) Renewal ( ) New Permit ( )

Permit Type: Radioactive Air Emissions Program Notice of Construction - WAC 246-247

Permitting Agency: Washington State Department of Health

Permit Number: Routine Technical Assistance Meeting

Permitted Unit: 318 Building High-Efficiency Particulate Air Filter Removal

Issuance Date: September 1995

Expiration Date: NA

Need for Headquarters' Action

(for permit renewals or new permits)
Yes ( ) No (X)

If yes, HQ Program Element

Brief Summary of Relevant Information (major permit conditions, status of compliance or unusual problems):

Approval of this Notice of Construction allowed the removal of high-efficiency particulate air filtration in the 318 Building. Approval was received from the Department of Health in September 1995. This activity was completed with no compliance issues.

Compiled by: Pacific Northwest National Laboratory

Date: July 31, 1997

\author{
Environmental Protection
}


DOE Operations Office: Richland

DOE Facility: Hanford Site

Existing Permit ( $X$ ) Renewal ( ) New Permit ( )

Permit Type: Radioactive Air Emissions Program Notice of Construction - WAC 246-247

Permitting Agency: Washington State Department of Health

Permit Number: Routine Technical Assistance Meeting

Permitted Unit: 324 Building Hood Installation

Issuance Date: September 1995

Expiration Date: NA

Need for Headquarters' Action

(for permit renewals or new permits)
Yes ( ) No (X)

If yes, HQ Program Element

Brief Summary of Relevant Information (major permit conditions, status of compliance or unusual problems):

Approval of this Notice of Construction allowed the installation of a hood in the 324 Building. The hood will be used to conduct soil melting experiments using a plasma arc for removal of loose equipment and packaging/removal for disposal. This activity was completed with no compliance issues.

Compiled by: Waste Management Federal Services of Hanford, Inc.

Date: July 31, 1997

Environmental Protection 
DOE Operations Office: Richland

DOE Facility: Hanford Site

Existing Permit ( ) Renewal ( ) New Permit (X)

Permit Type: National Emission Standards for Hazardous Air Pollutants (NESHAPs) 40 CFR 61, Subpart H

Permitting Agency: U.S. Environmental Protection Agency, Region 10

Permit Number:

Permitted Unit: 325 Building, Tritium Target Qualification Program

Issuance Date: March 3, 1997

Expiration Date: N/A

Need for Headquarters' Action

Yes ( ) No (X)

(for permit renewals or new permits)

If yes, HQ Program Element

Brief Summary of Relevant Information (major permit conditions, status of compliance or unusual problems):

Approval of this application allowed the sectioning of tritium target rods, tritium extraction and analysis, and ex-reactor tritium permeation tests. On March 3, 1997, an approval letter was received from the Washington State Department of Health. The research is ongoing and proceeded during the period covered by this Status Report with no compliance issues.

Compiled by: Pacific Northwest National Laboratory

Date: July 31, 1997

Environmental Protection 
DOE Operations Office: Richland

DOE Facility: Hanford Site

Existing Permit ( ) Renewal ( ) New Permit (X)

Permit Type: Radioactive Air Emissions Program, Radioactive Source Registration WAC 246-247

Permitting Agency: Washington State Department of Health

Permit Number:

Permitted Unit: 325 Building, Tritium Target Qualification Program

Issuance Date: March 28, 1997

Expiration Date: N/A

Need for Headquarters' Action

(for permit renewals or new permits)
Yes ( ) No (X)

If yes, HQ Program Element

Brief Summary of Relevant Information (major permit conditions, status of compliance or unusual problems):

Approval of this Notice of Construction allowed the sectioning of tritium target rods, tritium extraction and analysis, and ex-reactor tritium permeation tests. On March 28, 1997, an approval letter was received from the Washington State Department of Health. The research is ongoing and proceeded during the period covered by this Status Report with no compliance issues.

Compiled by: Pacific Northwest National Laboratory

Date: July 31, 1997

Environmental Protection 
DOE Operations Office: Richland

DOE Facility: Hanford Site

Existing Permit (X) Renewal ( ) New Permit ( )

Permit Type: Radioactive Air Emissions Program Notice of Construction - WAC 246-247

Permitting Agency: Washington State Department of Health

Permit Number: Routine Technicàl Assistance Meeting

Permitted Unit: 331 High-Efficiency Particulate Air Filter Bank Removal

Issuance Date: May 1996

Expiration Date: NA

Need for Headquarters' Action

(for permit renewals or new permits)
Yes ( ) No (X)

If yes, HQ Program Element

Brief Summary of Relevant Information (major permit conditions, status of compliance or unusual problems):

Approval of this Notice of Construction allowed the removal of a high-efficiency particulate air filter bank from the 331 Building. The high-efficiency particulate air filter replacement was approved in May 1996.

During the period covered by this Status Report, this activity proceeded with no compliance issues. This activity is complete.

Compiled by: Pacific Northwest National Laboratory

Date: July 31, 1997

Environmental Protection 
DOE Operations Office: Richland

DOE Facility: Hanford Site

Existing Permit ( ) Renewal ( ) N New Permit (X)

Permit Type:

Permitting Agency: Washington State Department of Ecology - WAC 173-400, WAC 173-460

Permit Number:

Permitted Unit: $340-$ NT-EX Emissions Unit

Issuance Date: May 5, 1997

Expiration Date: N/A

Need for Headquarters' Action

(for permit renewals or new permits)

Yes ( ) No (X)

If yes, HQ Program Element

Brief Summary of Relevant Information (major permit conditions, status of compliance or unusual problems):

Approval of this Notice of Construction allows removal of 340A Building tank solids. Future solids removal campaigns will be performed on an as-needed basis to support as low as reasonably achievable (ALARA) practices and/or principles. No more than one tank solids removal campaign will be performed during any given annual period.

Compiled by: Waste Management Federal Services of Hanford, Inc.

Date: July 31, 1997 for Fluor Daniel Hanford, Inc. 
DOE Operations Office: Richland

DOE Facility: Hanford Site

Existing Permit (X) $\quad$ Renewal ( ) New Permit ( )

Permit Type: National Emission Standards for Hazardous Air Pollutants (NESHAPs) 40 CFR 61, Subpart H

Permitting Agency: U.S. Environmental Protection Agency, Region 10

Permit Number: N/A

Permitted Unit: Applied Chemistry, 325 Building

Issuance Date: May 7, 1996

Expiration Date: N/A

Need for Headquarters' Action

(for permit renewals or new permits)
Yes ( ) No (X)

If yes, HQ Program Element

Brief Summary of Relevant Information (major permit conditions, status of compliance or unusual problems):

Approval of this application allows research to be conducted on special nuclear materials disposition and low-level waste vitrification. The research includes slurry and powder feeds, melting, quenching, and annealing of plutonium containing glasses. On May 7, 1996, an approval letter was received. This research work is ongoing.

Compiled by: Pacific Northwest National Laboratory

Date: July 31, 1997

Environmental Protection 
DOE Operations Office: Richland

DOE Facility: Hanford Site

Existing Permit (X) Renewal ( ) New Permit ( )

Permit Type: Radioactive Air Emissions Program Notice of Construction - WAC 246-247

Permitting Agency: Washington State Department of Health

Permit Number: AIR-96-604

Permitted Unit: Applied Chemistry, 325 Building

Issuance Date: June 7, 1996

Expiration Date: N/A

Need for Headquarters' Action

(for permit renewals or new permits)
Yes ( ) No (X)

If yes, HQ Program Element

Brief Summary of Relevant Information (major permit conditions, status of compliance or unusual problems):

Approval of this Notice of Construction allows research to be conducted on special nuclear materials disposition and low-level waste vitrification. The research includes slurry and powder feeds, melting, quenching, and annealing of plutonium containing glasses. Approval was received on June 7, 1996. This research work is ongoing.

Compiled by: Pacific Northwest National Laboratory

Date: July $31 ; 1997$ Environmental Protection 
DOE Operations Office: Richland

DOE Facility: Hanford Site

Existing Permit (X) Renewal ( ) N New Permit ( )

Permit Type: Radioactive Air Emissions Program Notice of Construction - WAC 246-247

Permitting Agency: Washington State Department of Health

Permit Number: Routine Technical Assistance Meeting

Permitted Unit: B Plant Canyon Exhaust Tunnel and D-Cell Video Inspection and Dose Measurements

Issuance Date: July 1996

Expiration Date: NA

Need for Headquarters' Action

(for permit renewals or new permits)
Yes ( ) No (X)

If yes, HQ Program Element

Brief Summary of Relevant Information (major permit conditions, status of compliance or unusual problems):

Approval of this Notice of Construction allows video inspection and dose measurements of the B Plant canyon exhaust tunnel and D-Cell.

During the period covered by this Status Report, the inspection and measurement activities proceeded with no compliance issues.

Compiled by: Waste Management Federal Services of Hanford, Inc.

Date: July 31, 1997 for Fluor Daniel Hanford, Inc. 
DOE Operations Office: Richland

DOE Facility: Hanford Site

Existing Permit ( ) Renewal ( ) New Permit (X)

Permit Type: Radioactive Air Emissions Program Notice of Construction — WAC 246-247

Permitting Agency: Washington State Department of Health/U.S. Environmental Protection Agency

Permit Number: Routine Technical Assistance Meeting

Permitted Unit: B Plant Organic Transfer Process and Storage System

Issuance Date: April 9, 1996 (Washington State Department of Health)

October 3, 1996 (U.S. Environmental Protection Agency)

Expiration Date: N/A

Need for Headquarters' Action

(for permit renewals or new permits)
Yes ( ) No (X)

If yes, HQ Program Element

Brief Summary of Relevant Information (major permit conditions, status of compliance or unusual problems):

The Notice of Construction allows the storage of contaminated organic in an outside storage tank. The storage tank is passively vented. A HEPA filter is installed as the passive vent line.

The organic was transferred from the B Plant canyon to a storage tank via hose lines with no compliance issues or unusual problems.

Compiled by: Waste Management Federal Services of Hanford, Inc. Date: July 31, 1997 for Fluor Daniel Hanford, Inc. 
DOE Operations Office: Richland

DOE Facility: Hanford Site

Existing Permit (X) Renewal ( ) New Permit ( )

Permit Type: Radioactive Air Emissions Program Notice of Construction - WAC 246-247

Permitting Agency: Washington State Department of Health

Permit Number: Routine Technical Assistance Meeting

Permitted Unit: B Plant Transition Activities

Issuance Date: April 1996

Expiration Date: NA

Need for Headquarters' Action

(for permit renewals or new permits)

\section{Yes ( ) No (X)}

If yes, HQ Program Element

Brief Summary of Relevant Information (major permit conditions, status of compliance or unusual problems):

Approval of this Notice of Construction allows activities to support the transition of B Piant to a deactivated status. This includes activities such as soap and water cleaning of the canyon deck.

During the period covered by this Status Report, these transition activities proceeded with no compliance issues.

Compiled by: Waste Management Federal Services of Hanford, Inc.

Date: July 31, 1997 for Fluor Daniel Hanford, Inc. 
DOE Operations Office: Richland

DOE Facility: Hanford Site

Existing Permit ( $\mathrm{X}$ )

Renewal ( )

New Permit ( )

Permit Type: Radioactive Air Emissions Program Notice of Construction - WAC 246-247

Permitting Agency: Washington State Department of Health

Permit Number: AlR-96-103

Permitted Unit: Canister Storage Building Phase I

Issuance Date: January 11, 1996

Expiration Date: N/A

Need for Headquarters' Action

(for permit renewals or new permits)

Yes ( ) No (X)

If yes, HQ Program Element

Brief Summary of Relevant Information (major permit conditions, status of compliance or unusual problems):

Approval of this Notice of Construction allows construction of Phase I of the Canister Storage Building in accordance with the conditions and descriptions contained in the Notice of Construction. Phase $I$ is defined as constructing the substructure, including, but not limited to, pouring the concrete for the floor and construction of exterior walls. A Phase II application must be approved before installation of the process equipment and emissions control equipment. There are no compliance issues, major permit conditions, or unusual problems associated with this project as of July 1997.

Compiled by: Waste Management Federal Services of Hanford, Inc. Date: July 31, 1997 for Fluor Daniel Hanford, Inc. 
DOE Operations Office: Richland

DOE Facility: Hanford Site

Existing Permit (X) Renewal ( ) New Permit ( )

Permit Type: National Emission Standard for Hazardous Air Pollutants (NESHAPs) 40 CFR 61, Subpart H

Permitting Agency: U.S. Environmental Protection Agency, Region 10

Permit Number: N/A

Permitted Unit: Canister Storage Building Phase I

Issuance Date: March 5, 1996

Expiration Date: N/A

Need for Headquarters' Action

(for permit renewals or new permits)
Yes ( ) No (X)

If yes, HQ Program Element

Brief Summary of Relevant Information (major permit conditions, status of compliance or unusual problems):

Approval of this application allows construction of Phase I of the Canister Storage Building in accordance with the conditions and descriptions contained in the application. Phase I is defined as constructing the substructure, including, but not limited to, pouring the concrete for the floor and construction of exterior walls. A Phase II application must be approved before installation of the process equipment and emissions control equipment.

During the period covered by this Status Report, these activities proceeded with no compliance issues.

Compiled by: Waste Management Federal Services of Hanford, Inc.

Date: July 31, 1997 for Fluor Daniel Hanford, Inc. 
DOE Operations Office: Richland

DOE Facility: Hanford Site

Existing Permit (X) Renewal ( ) New Permit ( )

$\begin{array}{ll}\text { Permit Type: } & \text { Notice of Construction for: } \\ & \text { General Regulations for Air Pollution Sources - WAC 173-400 }\end{array}$

Permitting Agency: Washington State Department of Ecology

Permit Number: AIR-95-1008 and AIR-95-1009

Permitted Unit: Central Waste Complex and Enhanced Radioactive and Mixed Waste Storage, Phase V

Issuance Date: October 24, 1995

Expiration Date: N/A

Need for Headquarters' Action

(for permit renewals or new permits)
Yes ( ) No (X)

If yes, HQ Program Element

Brief Summary of Relevant Information (major permit conditions, status of compliance or unusual problems):

- Approval of this Notice of Construction was for Central Waste Complex and Enhanced Radioactive and Mixed Waste Storage, Phase V. Phase V provides additional mixed waste storage capacity in three new buildings at the Central Waste Complex.

During the period covered by this Status Report, these activities proceeded with no compliance issues.

$\approx$ Compiled by: Waste Management Federal Services of Hanford, Inc.

Date: July 31, 1997 for Fluor Daniel Hanford, Inc. 
DOE Operations Office: Richland

DOE Facility: Hanford Site

Existing Permit ( $\mathrm{X}$ ) Renewal ( ) New Permit ( )

Permit Type: Radioactive Air Emissions Program Notice of Construction — WAC 246-247

Permitting Agency: Washington State Department of Health

Permit Number: N/A

Permitted Unit: Chemical Sciences Laboratory, 329 Building

Issuance Date: February 24, 1995

Expiration Date: N/A

Need for Headquarters' Action

(for permit renewals or new permits)
Yes ( ) No (X).

If yes, HQ Program Element

Brief Summary of Relevant Information (major permit conditions, status of compliance or unusual problems):

Approval of this Notice of Construction and other approvals allowed for the renovation of the Chemical Sciences Laboratory (329 Building) in the 300 Area. The renovation includes modernizing the laboratories and ventilation system to consolidate four emission points into a single exhaust stack. On February 24, 1995, an approval letter was received from the Department of Health. The renovation of the Chemical Sciences Laboratory is complete and the 329 Building is operational.

Compiled by:. Pacific Northwest National Laboratory

Date: July 31, 1997

Environmental Protection 
DOE Operations Office: Richland

DOE Facility: Hanford Site

Existing Permit (X) Renewal ( ) New Permit ( )

Permit Type: National Emission Standard for Hazardous Air Pollutants (NESHAPs) 40 CFR 61, Subpart H

Permitting Agency: U.S. Environmental Protection Agency, Region 10

Permit Number: N/A

Permitted Unit: Chemical Sciences Laboratory, 329 Building

Issuance Date: March 1, 1995

Expiration Date: N/A

Need for Headquarters' Action

(for permit renewals or new permits)

Yes ( ) No $(X)$

If yes, HQ Program Element

Brief Summary of Relevant Information (major permit conditions, status of compliance or unusual problems):

Approval of this application allowed for the renovation of the Chemical Sciences Laboratory (329 Building) in the 300 Area. The renovation includes modernizing the laboratories and ventilation system to consolidate four emission points into a single exhaust stack. On March 1, 1996, an approval letter was received from the EPA. The renovation of the Chemical Sciences Laboratory is complete and the 329 Building is operational.

Compiled by: Pacific Northwest National Laboratory

Date: July 31, 1997 Environmental Protection 
DOE Operations Office: Richland

DOE Facility: Hanford Site

Existing Permit ( ) Renewal ( ) New Permit (X)

Permit Type: Notice of Construction for:

General Regulations for Air Pollution Sources - WAC 173-400

Permitting Agency: Washington State Department of Ecology

Permit Number: NWP-95-329/300A

Permitted Unit: Chemical Sciences Laboratory, 329 Building

Issuance Date: June 5, 1996

Expiration Date: N/A

Need for Headquarters' Action

(for permit renewals or new permits)

Yes ( ) No (X)

If yes, HQ Program Element

Brief Summary of Relevant Information (major permit conditions, status of compliance or unusual problems):

Approval of this Notice of Construction allowed the renovation of the Chemical Sciences Laboratory (329 Building) in the 300 Area. The renovation included modernizing the laboratories and ventilation system to consolidate four emission points into a single exhaust stack. On September 18, 1996, an approval letter was received from Ecology, with emission limits for opacity and volatile organic compound compliance through a source test. The renovation of the Chemical Sciences Laboratory is complete and the 329 Building is operational.

Compiled by: Pacific Northwest National Laboratory

Date: July 31, 1997

Environmental Protection 
DOE Operations Office: Richland

DOE Facility: Hanford Site

Existing Permit ( ) Renewal ( ) New Permit (X)

Permit Type: National Emission Standard for Hazardous Air Pollutants (NESHAPs) 40 CFR 61, Subpart H

Permitting Agency: U.S. Environmental Protection Agency, Region 10

Permit Number: EPA letter dated January 10, 1997

Permitted Unit: Cold Vacuum Drying Facility

Issuance Date: January 10, 1997

Expiration Date: N/A

Need for Headquarters' Action

(for permit renewals or new permits)

Yes ( ) No (X)

If yes, HQ Program Element

Brief Summary of Relevant Information (major permit conditions, status of compliance or unusual problems):

Approval of this application allows for placement of the Cold Vacuum Drying Facility. The Cold Vacuum Drying Facility is one of three facilities that will be designed and constructed to complete the retrieval, processing, and storage of the spent nuclear fuel from the 105-K East and 105-K West Basins.

There are no compliance issues, major permit conditions, or unusual problems associated with this project as of July 1997.

Compiled by: Waste Management Federal Services of Hanford, Inc. Date: July 31, 1997 for Fluor Daniel Hanford, Inc. 
DOE Operations Office: Richland

DOE Facility: Hanford Site

Existing Permit ( ) Renewal ( ) New Permit (X)

Permit Type: General Regulations for Air Pollution Sources - WAC 173-400

Permitting Agency: State of Washington Department of Ecology

Permit Number: 96NM-091 dated September 30, 1996

Permitted Unit: Cold Vacuum Drying Facility, Phase I

Issuance Date: September 30, 1996

Expiration Date: N/A

Need for Headquarters' Action

(for permit renewals or new permits)

Yes ( ). No $(X)$

If yes, HQ Program Element

Brief Summary of Relevant Information (major permit conditions, status of compliance or unusual problems):

Approval of this Notice of Construction allows constructing the substructure, including but not limited to, pouring concrete for the floor, and construction of the exterior walls for the Cold Vacuum Drying Facility (CVDF), Phase I. A Phase II Notice of Construction will be submitted for approval before installation of the process equipment that will generate any potential air emissions at the CVDF.

During the reporting period covered by this Status Report, these activities proceeded with no compliance issues.

Compiled by: Waste Management Federal Services of Hanford, Inc.

Date: July 31, 1997 for Fluor Daniel Hanford, Inc. 
DOE Operations Office: Richland

DOE Facility: Hanford Site

Existing Permit ( ) $\quad$ Renewal ( ) New Permit (X)

Permit Type: Radioactive Air Emissions Program Notice of Construction - WAC 246-247

Permitting Agency: Washington State Department of Health

Permit Number: AIR 97-605

Permitted Unit: Cold Vacuum Drying Facility, Phase II

Issuance Date: June 10, 1997

Expiration Date: N/A

Need for Headquarters' Action

(for permit renewals or new permits)
Yes ( ) No ( $\mathrm{X}$ )

If yes, HQ Program Element

Brief Summary of Relevant Information (major permit conditions, status of compliance or unusual problems):

The Cold Vacuum Drying Facility is one of three facilities that will be designed and constructed to complete the retreival, processing, and storage of the spent nuclear fuel from the 105-K East and 105$\mathrm{K}$ West Basins. The Phase I Notice of Construction was submitted to ensure the CVDF is in full compliance with WAC 173-460-040 (8) "Commencement of construction." The Phase I Notice of Construction is defined as constructing the substructure, including but not limited to, pouring concrete for the floor, and construction of the exterior walls. The Phase II Notice of Construction allows installation of the process equipment that will generate any potential air emissions at the CVDF.

During the reporting period covered by this Status Report, these activities proceeded with no compliance issues.

Compiled by: Waste Management Federal Services of Hanford, Inc.

Date: July 31, 1997 for Fluor Daniel Hanford, Inc. 
DOE Operations Office: Richland

DOE Facility: Hanford Site

$\begin{array}{lll}\text { Existing Permit (X) } & \text { Renewal ( ) } & \text { New Permit ( ) }\end{array}$

Permit Type: Radioactive Air Emissions Program Notice of Construction - WAC 246-247

Permitting Agency: Washington State Department of Health

Permit Number: N/A

Permitted Unit: Emergency Dump Basin

Issuance Date: March 25, 1996

Expiration Date: N/A

Need for Headquarters' Action Yes ( ) No (X) (for permit renewals or new permits) If yes, HQ Program Element

Brief Summary of Relevant Information (major permit conditions, status of compliance or unusual problems):

Approval of this Notice of Construction allows for the stabilization of the Emergency Dump Basin. The project began on July 9,1996 , and work is in progress.

During the period covered by this Status Report, the Emergency Dump Basin remediation activities proceeded with no compliance issues.

Compiled by: Bechtel Hanford, Inc

Date: July 31, 1997

Regulatory Support 
DOE Operations Office: Richland

DOE Facility: Hanford Site

Existing Permit (X) $\quad$ Renewal ( ) New Permit ( )

Permit Type: National Emission Standard for Hazardous Air Pollutants (NESHAPs) - . 40 CFR 61, Subpart H

Permitting Agency: U.S. Environmental Protection Agency, Region 10

Permit Number: N/A

Permitted Unit: Emergency Dump Basin

Issuance Date: June 27, 1996

Expiration Date: N/A

Need for Headquarters' Action

Yes ( ) No ( $\mathrm{X}$ )

(for permit renewals or new permits)

If yes, HQ Program Element

Brief Summary of Relevant Information (major permit conditions, status of compliance or unusual problems):

Approval of this application allows for the stabilization of the Emergency Dump Basin. The project began on July 9, 1996, and work is in progress.

During the period covered by this Status Report, the Emergency Dump Basin activities proceeded with no compliance issues.

Compiled by: Bechtel Hanford, Inc.

Date: July 31, 1997

Regulatory Support 
DOE Operations Office: Richland

DOE Facility: Hanford Site

Existing Permit (X) Renewal ( ) New Permit ( )

Permit Type: . Radioactive Air Emissions Program Notice of Construction - WAC 246-247

Permitting Agency: Washington State Department of Health

Permit Number: AIR 95-407

Permitted Unit: Environmental Analytical Laboratory

Issuance Date: April 13, 1995

Expiration Date: N/A

Need for Headquarters' Action

(for permit renewals or new permits)
Yes ( ) No (X) If yes, HQ Program Element

Brief Summary of Relevant Information (major permit conditions, status of compliance or unusual problems):

Approval of this Notice of Construction allows the Environmental Analytical Laboratory to perform timely radiological screening and analyses. Approval was received from the Department of Health on April 13, 1995. Limited screening and analysis activities began in May 1995, and are continuing.

Compiled by: Bechtel Hanford, Inc.

Date: July 31, 1997

Regulatory Support 
DOE Operations Office: Richland

DOE Facility: Hanford Site

Existing Permit ( $\mathrm{X}$ ) Renewal ( ) New Permit ( )

Permit Type: National Emission Standard for Hazardous Air Pollutants (NESHAPs) 40 CFR 61, Subpart H

Permitting Agency: U.S. Environmental Protection Agency, Region 10

Permit Number: N/A

Permitted Unit: Environmental Analytical Laboratory

Issuance Date: April 27, 1995

Expiration Date: N/A

Need for Headquarters' Action

(for permit renewals or new permits)
Yes ( ) No (X)

If yes, HQ Program Element

Brief Summary of Relevant Information (major permit conditions, status of compliance or unusual problems):

Approval of this application allows the Environmental Analytical Laboratory to perform timely radiological screening and analysis. Approval was received from the EPA on April 27, 1995. Limited screening and analysis activities began in May 1995, and are continuing.

Compiled by: Bechtel Hanford, Inc.

Date: July 31, 1997

Regulatory Support 
DOE Operations Office: Richland

DOE Facility: Hanford Site

Existing Permit (X) Renewal ( ) New Permit ( )

Permit Type: Notice of Construction for:

General Regulations for Air Pollution Sources - WAC 173-400

Controls for New Sources of Toxic Air Pollutants - WAC 173-460

Permitting Agency: Washington State Department of Ecology

Permit Number: NWP-95(8)-100N/EAL

Permitted Unit: Environmental Analytical Laboratory

Issuance Date: November 15, 1995

Expiration Date: N/A

Need for Headquarters' Action

(for permit renewals or new permits)
Yes ( ) No (X)

If yes, HQ Program Element

Brief Summary of Relevant Information (major permit conditions, status of compliance or unusual problems):

Approval of this Notice of Construction allows the Environmental Analytical Laboratory to perform timely nonradiological screening and analyses. Approval was received from Ecology on November 15, 1995. Limited nonradiological analysis was conducted in 1995 and early 1996. Since early 1996, no analysis has been conducted.

Compiled by: Bechtel Hanford, Inc.

Date: July 31, 1997

Regulatory Support 
DOE Operations Office: Richland

DOE Facility: Hanford Site

Existing Permit (X) Renewal ( ) New Permit ( )

Permit Type: Radioactive Air Emissions Program Notice of Construction — WAC 246-247

Permitting Agency: Washington State Department of Health

Permit Number: AIR-94-803

Permitted Unit: Environmental Molecular Sciences Laboratory

Issuance Date: August 2, 1994

Expiration Date: N/A

Need for Headquarters' Action

(for permit renewals or new permits)

Yes ( ) No (X)

If yes, HQ Program Element

Brief Summary of Relevant Information (major permit conditions, status of compliance or unusual problems):

Approval of this Notice of Construction allows the Environmental Molecular Sciences Laboratory to be constructed and to operate in a location near the 300 Area. The Environmental Molecular Sciences Laboratory is a new multi-user laboratory providing the necessary complement of capabilities designed for research and development activities to solve environmental restoration and waste management problems on the Hanford Site. On August 2, 1994, an approval letter was received from the Department of Health. The Environmental Molecular Sciences Laboratory is currently under preparation for operational startup.

Compiled by: Pacific Northwest National Laboratory

Date: July 31, 1997

Environmental Protection 
DOE Operations Office: Richland

DOE Facility: Hanford Site

Existing Permit (X) Renewal ( ) New Permit ( )

Permit Type: National Emission Standard for Hazardous Air Pollutants (NESHAPs) 40 CFR 61, Subpart H

Permitting Agency: U.S. Environmental Protection Agency, Region 10

Permit Number: N/A

Permitted Unit: Environmental Molecular Sciences Laboratory

İssuance Date: July 6, 1994

Expiration Date: N/A

Need for Headquarters' Action

(for permit renewals or new permits)
Yes ( ) No (X)

If yes, HQ Program Element

Brief Summary of Relevant Information (major permit conditions, status of compliance or unusual problems):

Approval of this application allows the Environmental Molecular Sciences Laboratory to be constructed and to operate in a location near the 300 Area. The Environmental Molecular Sciences Laboratory is a new multi-user laboratory providing the necessary complement of capabilities designed for research and development activities to solve environmental restoration and waste management problems on the Hanford Site. On July 6, 1994, an approval letter was received from the EPA. The Environmental Molecular Sciences Laboratory is currently under preparation for operational startup.

Compiled by: Pacific Northwest National Laboratory Environmental Protection

Date: July 31,1997 
DOE Operations Office: Richland

DOE Facility: Hanford Site

Existing Permit (X) Renewal ( ) New Permit ( )

Permit Type: Notice of Construction for:

General Regulations for Air Pollution Sources - WAC 173-400

Controls for New Sources of Toxic Air Pollutants - WAC 173-460

Permitting Agency: Washington State Department of Ecology

Permit Number: NOC-94-08

Permitted Unit: Environmental Molecular Sciences Laboratory

Issuance Date: September 12, 1994

Expiration Date: N/A

Need for Headquarters' Action

Yes ( ) No (X)

(for permit renewals or new permits)

If yes, HQ Program Element

Brief Summary of Relevant Information (major permit conditions, status of compliance or unusual problems):

Approval of this Notice of Construction allows the Environmental Molecular Sciences Laboratory to be constructed and to operated in a location near the 300 Area. The Environmental Molecular Sciences Laboratory is a new multi-user laboratory providing the necessary complement of capabilities designed for research and development activities to solve environmental restoration and waste management problems on the Hanford Site. The Notice of Construction was approved by Ecology on September 12, 1994, with emission limits for ammonia and volatile organic compounds, as well as source testing requirements. The Environmental Molecular Sciences Laboratory is currently under preparation for operational startup.

Compiled by: Pacific Northwest National Laboratory

Date: July 31, 1997

Environmental Protection 
DOE Operations Office: Richland

DOE Facility: Hanford Site

Existing Permit ( ) Renewal ( ) New Permit (X)

Permit Type: Radioactive Air Emissions Program Notice of Construction - WAC 246-247

Permitting Agency: Washington State Department of Health

Permit Number: AlR 96-905

Permitted Unit: Hot Conditioning System Annex, Phase I

Issuance Date: September 11, 1996

Expiration Date: N/A

Need for Headquarters' Action

(for permit renewals or new permits)

Yes ( ) No (X)

If yes, HQ Program Element

Brief Summary of Relevant Information (major permit conditions, status of compliance or unusual problems):

Approval of this Notice of Construction is for constructing the substructure, including but not limited to, pouring concrete for the floor, and construction of the exterior walls; making necessary interface connections to the Canister Storage Building ventilation and utility systems for personal comfort; and extending the multi-canister overpack handling machine rails into the Hot Conditioning System Annex. A Phase II Notice of Construction will be submitted for approval before installation of the process equipment that will generate any potential air emissions at the Hot Conditioning System Annex.

There are no compliance issues, major permit conditions, or unusual problems associated with this project as of July 1997.

Compiled by: Waste Management Federal Services of Hanford, Inc. for Fluor Daniel Hanford, Inc.

Date: July 31, 1997 
DOE Operations Office: Richland

DOE Facility: Hanford Site

Existing Permit ( ) Renewal ( ) New Permit (X)

Permit Type: Controls for New Sources of Toxic Air Pollutants - WAC 173-460

Permitting Agency: State of Washington Department of Ecology

Permit Number: 96NM-092 dated October 3, 1996

Permitted Unit: Hot Conditioning System Annex, Phase I

Issuance Date: October 3, 1996

Expiration Date: N/A

Need for Headquarters' Action

Yes ( ) No (X)

(for permit renewals or new permits)

If yes, $\mathrm{HQ}$ Program Element

Brief Summary of Relevant Information (major permit conditions, status of compliance or unusual problems):

Approval of this Notice of Construction is for constructing the substructure, including but not limited to, pouring concrete for the floor, and construction of the exterior walls; making necessary interface connections to the Canister Storage Building ventilation and utility systems for personal comfort; and extending the multi-canister overpack handling machine rails into the Hot Conditioning System Annex. A Phase II Notice of Construction will be submitted for approval before installation of the process equipment that will generate any potential air emissions at the Hot Conditioning System Annex.

There are no compliance issues, major permit conditions, or unusual problems associated with this project as of July 1997.

Compiled by: Waste Management Federal Services of Hanford, Inc.

Date: July 31, 1997 for Fluor Daniel Hanford, Inc. 
DOE Operations Office: Richland

DOE Facility: Hanford Site

Existing Permit (X) Renewal ( ) New Permit ( )

Permit Type: Radioactive Air Emissions Program Notice of Construction — WAC 246-247

Permitting Agency: Washington State Department of Health

Permit Number: Routine Technical Assistance Meeting

Permitted Unit: Inactive Miscellaneous Underground Storage Tanks Sampling/Characterization

Issuance Date: January 9, 1996

Expiration Date: September 30, 1997

Need for Headquarters' Action

(for permit renewals or new permits)
Yes ( ) No (X)

If yes, HQ Program Element

Brief Summary of Relevant Information (major permit conditions, status of compliance or unusual problems):

Approval of this Notice of Construction allows the sampling/characterization of the balance of the inactive miscellaneous underground storage tanks (approximately 36 ). This activity was amended to the Tank Farm Routine Activities List. Negotiation for extending the Notice of Construction are ongoing.

During the period covered by this Status Report, these activities proceeded with no compliance issues.

Compiled by: Waste Management Federal Services of Hanford, Inc.

Date: July 31, 1997

for Fluor Daniel Hanford, Inc. 
DOE Operations Office: Richland

DOE Facility: Hanford Site

Existing Permit (X) Renewal ( ) New Permit ( )

Permit Type: Radioactive Air Emissions Program Notice of Construction - WAC 246-247

Permitting Agency: Washington State Department of Health

Permit Number: AIR-96-902

Permitted Unit: Initial Tank Retrieval System for 241-SY-102 Tank, Project W-211

Issuance Date: September 11, 1996

Expiration Date: March 11, 1998

Need for Headquarters' Action

(for permit renewals or new permits)

Yes ( ) No (X)

If yes, HQ Program Element

Brief Summary of Relevant Information (major permit conditions, status of compliance or unusual problems):

Approval of this Notice of Construction allows for the installation and operation of two mixer pumps in the 241-SY-102 tank in accordance with descriptions contained in the Notice of Construction. Other conditions require head space sampling during startup and peak operations and exclusive use of the new primary exhauster during peak operation. The primary objective of the Initial Tank Retrieval System is to support tank waste treatment and disposal. The retrieval capabilities also are used to consolidate compatible tank waste to create additional double-shell tank storage space. Construction of this project was delayed by the DOE-RL until the year 2002.

Compiled by: Waste Management Federal Services of Hanford, Inc.

Date: July 31, 1997 for Fluor Daniel Hanford, Inc. 
DOE Operations Office: Richland

DOE Facility: Hanford Site

Existing Permit (X) Renewal ( ) . New Permit ( )

Permit Type: National Emission Standard for Hazardous Air Pollutants (NESHAPs) 40 CFR 61, Subpart H

Permitting Agency: U.S. Environmental Protection Agency, Region 10

Permit Number: N/A

Permitted Unit: Initial Tank Retrieval System for 241-SY-102 Tank, Project W-211

Issuance Date: March 15, 1996

Expiration Date: September 15, 1998

Need for Headquarters' Action

(for permit renewals or new permits)

Yes ( ) No (X)

If yes, HQ Program Element

Brief Summary of Relevant Information (major permit conditions, status of compliance or unusual problems):

Approval of this application allows for the installation and operation of two mixer pumps in the 241-SY-102 tank in accordance with descriptions contained in the application: Other conditions require head space sampling during startup and peak operations and exclusive use of the new primary exhauster during peak operation. The primary objective of the Initial Tank Retrieval System is to support tank waste treatment and disposal. The retrieval capabilities also are used to consolidate compatible tank waste to create additional double-shell tank storage space. Construction of this project was formally postponed by the DOE-RL until the year 2002 .

Compiled by: Waste Management Federal Services of Hanford, Inc.

Date: July 31, 1997 for Fluor Daniel Hanford, Inc. 
DOE Operations Office: Richland

DOE Facility: Hanford Site

Existing Permit ( ) Renewal ( ) New Permit (X)

Permit Type: Radioactive Air Emissions Program Notice of Construction - WAC 246-247

Permitting Agency: Washington State Department of Ecology

Permit Number: N/A

Permitted Unit: ODEX ${ }^{1}$ Drilling System

Issuance Date: October 8, 1996

Expiration Date: N/A

Need for Headquarters' Action

(for permit renewals or new permits)

Yes ( ) No (X)

If yes, HQ Program Element

Brief Summary of Relevant Information (major permit conditions, status of compliance or unusual problems):

Approval of this Notice of Construction allows use of the ODEX method of air-assisted drilling for development of groundwater monitoring wells to support RCRA project characterization.

During the period covered by this Status Report, there were no compliance issues or unusual problems.

${ }^{1} \mathrm{ODEX}$ is a trademark. Patent presently owned by Sandvig Corporation.

Compiled by: Waste Management Federal Services of Hanford, Inc. for Fluor Daniel Hanford, Inc.

Date: July 31, 1997 
DOE Operations Office: Richland

DOE Facility: Hanford Site

Existing Permit (X) Renewal ( ) New Permit ( )

Permit Type: Radioactive Air Emissions Program Notice of Construction - WAC 246-247

Permitting Agency: Washington State Department of Health

Permit Number: Routine Technical Assistance Meeting

Permitted Unit: Operation of Portable Exhauster in Conjunction with the Light Duty Utility Arm Issuance Date: March 3, 1996

Expiration Date: NA

Need for Headquarters' Action (for permit renewals or new permits)
Yes ( ) No (X) If yes, HQ Program Element

Brief Summary of Relevant Information (major permit conditions, status of compliance or unusual problems):

Approval of this Notice of Construction allows the use of the Light Duty Utility Arm in conjunction with an exhauster on passively ventilated single-shell tanks as a contingency measure: The Light Duty Utility Arm is a tank characterization tool developed to characterize the contents of single-shell and double-shell tanks, especially in areas not directly below the access risers. The Light Duty Utility Arm normally is operated without an exhauster; however, use of an exhauster adds flexibility for the possibility of fog in a tank or to satisfy a safety requirement to actively ventilate a tank.

During the period covered by this Status Report, the operation of a portable exhauster in conjunction with the Light Duty Utility Arm proceeded with no compliance issues.

Compiled by: Waste Management Federal Services of Hanford, Inc.

Date: July 31, 1997 for Fluor Daniel Hanford, Inc. 
DOE Operations Office: Richland

DOE Facility: Hanford Site

Existing Permit (X) Renewal ( ) New Permit ( )

Permit Type: National Emission Standard for Hazardous Air Pollutants (NESHAPs) 40 CFR 61, Subpart H

Permitting Agency: U.S. Environmental Protection Agency, Region 10

Permit Number: N/A

Permitted Unit: Operation of a Portable Exhauster in Conjunction with the Light Duty Utility Arm

Issuance Date: July 2, 1996

Expiration Date: N/A

Need for Headquarters' Action

(for permit renewals or new permits)
Yes ( ) No (X)

If yes, HQ Program Element

Brief Summary of Relevant Information (major permit conditions, status of compliance or unusual problems):

Approval of this application allows for the operation of a portable exhauster on passively ventilated tanks while deploying a Light Duty Utility Arm in accordance with descriptions contained in the application. The Light Duty Utility Arm is a tank characterization tool developed to characterize the contents of single-shell and double-shell tanks, especially in areas not directly below the access risers. The Light Duty Utility Arm normally is operated without an exhauster; however, use of an exhauster adds flexibility for the possibility of fog in a tank or to satisfy a safety requirement to actively ventilate a tank

During the period covered by this Status Report, the operation of a portable exhauster in conjunction with the Light Duty Utility Arm proceeded with no compliance issues.

Compiled by: Waste Management Federal Services of Hanford, Inc.

Date: July 31, 1997 for Fluor Daniel Hanford, Inc. 
DOE Operations Office: Richland

DOE Facility: Hanford Site

Existing Permit (X) Renewal ( ) New Permit ()

Permit Type: Radioactive Air Emissions Program Notice of Construction - WAC 246-247

Permitting Agency: Washington State Department of Health

Permit Number: AIR-96-403

Permitted Unit: Plasma Arc Furnace, 324 Building

Issuance Date: April 18, 1996

Expiration Date: N/A

Need for Headquarters' Action

(for permit renewals or new permits)
Yes ( ) No (X)

If yes, HQ Program Element

Brief Summary of Relevant Information (major permit conditions, status of compliance or unusual problems):

Approval of this Notice of Construction allows construction of a large walk-in fume hood containing a direct current plasma arc furnace and its associated offgas treatment and feed systems. On April 18, 1996, an approval letter was received from the Department of Health. Preparations are underway to operate the plasma arc furnace.

Compiled by: Waste Management Federal Service of Hanford, Inc.

Date: July 31, 1997 for Fluor Daniel Hanford, Inc. 
DOE Operations Office: Richland

DOE Facility: Hanford Site

Existing Permit (X) Renewal ( ) New Permit ( )

Permit Type: National Emission Standard for Hazardous Air Pollutants (NESHAPs) 40 CFR 61, Subpart H

Permitting Agency: U.S. Environmental Protection Agency, Region 10

Permit Number: N/A

Permitted Unit: Plasma Arc Furnace, 324 Building

Issuance Date: April 3, 1996

Expiration Date: N/A

Need for Headquarters' Action

(for permit renewals or new permits)
Yes ( ) No (X)

If yes, HQ Program Element

Brief Summary of Relevant Information (major permit conditions, status of compliance or unusual problems):

Approval of this application allows construction of a large walk-in fume hood containing a direct current plasma arc furnace and its associated offgas treatment and feed systems. On April 3, 1996, an approval letter was received from the EPA. Preparations are underway to operate the plasma arc furnace.

Compiled by: Waste Management Federal Services of Hanford, Inc.

Date: July 31, 1997 for Fluor Daniel Hanford, Inc. 
DOE Operations Office: Richland

DOE Facility: Hanford Site

Existing Permit (X) Renewal ( ) New Permit ( )

Permit Type: Notice of Construction for:

General Regulations for Air Pollution Sources - WAC 173-400

Controls for New Sources of Toxic Air Pollutants - WAC 173-460

Permitting Agency: Washington State Department of Ecology

Permit Number: NWP-96-2

Permitted Unit: Plasma Arc Furnace, 324 Building

Issuance Date: May 20, 1996

Expiration Date: N/A

Need for Headquarters' Action

(for permit renewals or new permits)
Yes ( ) No (X).

If yes, HQ Program Element

Brief Summary of Relevant Information (major permit conditions, status of compliance or unusual problems):

Approval of this Notice of Construction allows construction of a large walk-in fume hood containing a direct current plasma arc furnace and its associated offgas treatment and feed systerts. On May 20,1996, a permit was received from Ecology. Preparations are underway to operate the plasma arc furnace.

Compiled by: Waste Management Federal Services of Hanford, Inc.

Date: July $3 \leqslant-1997$ Environmental Protection 
DOE Operations Office: Richland

DOE Facility: Hanford Site
Existing Permit ( $\mathrm{X}$ )
Renewal ( )
New Permit ( )

Permit Type: Radioactive Air Emissions Program Notice of Construction - WAC 246-247

Permitting Agency: Washington State Department of Health

Permit Number: Routine Technical Assistance Meeting

Permitted Unit: Plutonium Finishing Plant Cementation of Plutonium Bearing Materials

Issuance Date: May 1996

Expiration Date: NA

Need for Headquarters' Action

(for permit renewals or new permits)

Yes ( ) No (X).

If yes, HQ Program Element

Brief Summary of Relevant Information (major permit conditions, status of compliance or unusual problems):

Approval of this Notice of Construction allows the cementation of plutonium bearing materials. The cementation process will be consolidated into one location and will be similar to those cementing operations that the Plutonium Finishing Plant has done before in several gloveboxes. The rate of handling plutonium-bearing material was roughly equivalent to other routine glovebox operations in the Plutonium Finishing Plant. A description of the cementation activity also is discussed in the approved Plutonium Finishing Plant stabilization environmental impact statement.

During the period covered by this Status Report, this activity proceeded with no compliance issues.

Compiled by: Waste Management Federal Services of Hanford, Inc.

Date: July 31, 1997 for Fluor Daniel Hanford, Inc. 
DOE Operations Office: Richland

DOE Facility: Hanford Site
Existing Permit $(\mathrm{X})$
Renewal ( )
New Permit ( )

Permit Type: Radioactive Air Emissions Program Notice of Construction - WAC 246-247

Permitting Agency: Washington State Department of Health

Permit Number: Routine Technical Assistance Meeting

Permitted Unit: Plutonium Finishing Plant Duct Work and Process Piping Remediation

Issuance Date: July 1996

Expiration Date: NA

Need for Headquarters' Action

(for permit renewals or new permits)

Yes ( ) No (X)

If yes, HQ Program Element

Brief Summary of Relevant Information (major permit conditions, status of compliance or unusual problems):

Approval of this Notice of Construction allows an additional 35-foot segment of small diameter vacuum process piping to be remediated under the same conditions of a previously approved Notice of Construction. The additional 35 feet of piping has a source term of about 2 kilograms of plutonium. This additional work will not have a dose potential exceeding 0.1 millirem per year.

During the period covered by this Status Report, the remediation work at Plutonium Finishing Plant proceeded with no compliances issues.

Compiled by: Waste Management Federal Services of Hanford, Inc. for Fluor Daniel Hanford, Inc. 
DOE Operations Office: Richland

DOE Facility: Hanford Site

Existing Permit ( ) : Renewal ( ) New Permit (X)

Permit Type: National Emission Standard for Hazardous Air Pollutants (NESHAPs) 40 CFR 61, Subpart H

Permitting Agency: U.S. Environmental Protection Agency, Region 10

Permit Number: N/A

Permitted Unit: Plutonium Finishing Plant Ductwork and Process Piping Remediation Modification

Issuance Date: September 3, 1996

Expiration Date: N/A

Need for Headquarters' Action

(for permit renewals or new permits)
Yes ( ) No (X)

If yes, HQ Program Element

Brief Summary of Relevant Information (major permit conditions, status of compliance or unusual problems):

Approval of this application allows for an additional 35-foot segment of vacuum process piping to be remediated under the same conditions of a previously approved application. The additional 35 feet of piping has a source limit of about 2 kilograms of plutonium. This additional work will not have a dose potential exceeding 0.1 millirem per year.

Compiled by: Waste Management Federal Services of Hanford, Inc.

Date: July 31, 1997 for Fluor Daniel Hanford, Inc. 
DOE Operations Office: Richland

DOE Facility: Hanford Site

Existing Permit ( $\mathrm{X}$ )

Renewal ( )

New Permit ( )

Permit Type: Radioactive Air Emissions Program Notice of Construction - WAC 246-247

Permitting Agency: Washington State Department of Health

Permit Number: N/A

Permitted Unit: Plutonium Finishing Plant Low-Level Waste Treatment Facility

Issuance Date: July 30, 1992

Expiration Date: N/A

Need for Headquarters' Action

(for permit renewals or new permits)
Yes ( ) No (X)

If yes, HQ Program Element

Brief Summary of Relevant Information (major permit conditions, status of compliance or unusual problems):

Approval of this Notice of Construction allows construction of the Plutonium Finishing Plant Low-Level Waste Treatment Facility using approved radionuclide air emissions control equipment. This facility treats low-level waste water from the Plutonium Finishing Plant. No revisions of the Radioactive Air Emissions Program Notice of Construction have been submitted

During the period covered by this Status Report, the Low-Level Waste Treatment Facility activities proceeded with no compliance issues.

Compiled by: Waste Management Federal Services of Hanford, Inc. for Fluor Daniel Hanford, Inc.

Date: July 31, 1997 
DOE Operations Office: Richland

DOE Facility: Hanford Site

Existing Permit ( ) Renewal ( ) New Permit (X)

Permit Type: Categorical Approval for Construction and Operation - WAC 246-247

Permitting Agency: Washington State Department of Health

Permit Number: AIR-96-1103

Permitted Unit: Portable Exhausters

Issuance Date: November 8, 1996

Expiration Date: N/A

Need for Headquarters' Action

(for permit renewals or new permits)
Yes ( ) No (X)

If yes, HQ Program Element

Brief Summary of Relevant Information (major permit conditions, status of compliance or unusual problems):

The Categorical Approval for Construction and Operation is a Hanford Sitewide Categorical Approval to construct and operate portable and temporary radionuclide airborne emissions equipment. The Notice of Construction requested permission to construct and operate portable and temporary radionuclide airborne emissions systems without prior notification to the Department of Health if expected emissions from each of the systems were below 0.1 milliroentgen equivalent man per year. Because portable and temporary radionuclide airborne emissions systems are operated mainly for temporary and emergency conditions. this Categorical Approval allows expedited response to field situations requiring such systems.

Compiled by: Waste Management Federal Services of Hanford, Inc.

Date: July 31, 1997 for Fluor Daniel Hanford, Inc. 
DOE Operations Office: Richland

DOE Facility: Hanford Site

Existing Permit (X) Renewal ( ) New Permit ( )

Permit Type: Radioactive Air Emissions Program Notice of Construction - WAC 246-247

Permitting Agency: Washington State Department of Health

Permit Number: Routine Technical Assistance Meeting

Permitted Unit: Portable Exhauster for Flammable Watchlist Single-Shell Tank System

Issuance Date: July 11, 1995

Expiration Date: N/A

Need for Headquarters' Action

(for permit renewals or new permits)

Yes ( ) No (X)

If yes, HQ Program Element

Brief Summary of Relevant Information (major permit conditions, status of compliance.or unusual problems):

Approval of this Notice of Construction allows the use of a portable exhauster on single-shell tanks included on the flammable watchlist using approved radionuclide air emissions control equipment in accordance with descriptions contained in the application. To mitigate personnel safety concerns during the installation of the thermocouple trees and other equipment, an active means of removing vapors from the tanks is provided when waste intrusive work is being performed.

During the period covered by this Status Report, the portable exhausters operated with no compliance issues.

Compiled by: Waste Management Federal Services of Hanford, Inc.

Date: July 31, 1997 for Fluor Daniel Hanford, Inc. 
DOE Operations Office: Richland

DOE Facility: Hanford Site

Existing Permit (X) Renewal ( ) New Permit ( )

Permit Type: National Emission Standard for Hazardous Air Pollutants (NESHAPs) 40 CFR 61, Subpart H

Permitting Agency: U.S. Environmental Protection Agency, Region 10

Permit Number: I96-PCA-145

Permitted Unit: Portable Exhauster for Flammable Watchlist Single-Shell Tank System

Issuance Date: December 6, 1995

Expiration Date: N/A

Need for Headquarters' Action

(for permit renewals or new permits)
Yes () No (X)

If yes, HQ Program Element

Brief Summary of Relevant Information (major permit conditions, status of compliance or unusual problems):

Approval of this application allows the use of a portable exhauster on single-shell tanks included on the flammable watchlist in accordance with descriptions contained in the application. To mitigate personnel safety concerns during the installation of the thermocouple trees and other equipment, an active means of removing vapors from the tanks is provided when waste intrusive work is being performed.

During the period covered by this Status Report, the portable exhausters operated with no compliance issues.

Compiled by: Waste Management Federal Services of Hanford, Inc.

Date: July 31, 1997 for Fluor Daniel Hanford, Inc. 
DOE Operations Office: Richland

DOE Facility: Hanford Site

Existing Permit (X) Renewal ( ) New Permit ( )

Permit Type: Radioactive Air Emissions Program Notice of Construction - WAC 246-247

Permitting Agency: Washington State Department of Health

Permit Number: AIR-94-313

Permitted Unit: PUREX Plant Deactivation

Issuance Date: March 30, 1994

Expiration Date: N/A

Need for Headquarters' Action

(for permit renewals or new permits)
Yes ( ) No (X)

If yes, HQ Program Element

Brief Summary of Relevant Information (major permit conditions, status of compliance or unusual problems):

Approval of this Notice of Construction allows deactivation activities to prepare the PUREX Plant for final closure and decommissioning. Approval was granted contingent on the deactivation being operated in accordance with descriptions contained in the application. The $\mathrm{UO}_{3}$ and PUREX facilities addressed with limits in the Notice of Construction have been permanently shutdown.

During the period covered by this Status Report, the PUREX Plant deactivation proceeded with no compliance issues.

Compiled by: Waste Management Federal Services of Hanford, Inc.

Date: July 31, 1997 for Fluor Daniel Hanford, Inc. 
DOE Operations Office: Richland.

DOE Facility: Hanford Site

Existing Permit (X) Renewal ( ) New Permit ( )

Permit Type: Radioactive Air Emissions Program Notice of Construction — WAC 246-247

Permitting Agency: Washington State Department of Health

Permit Number: AIR-95-803

Permitted Unit: Radon Research Facility, 331 Building

Issuance Date: August 8, 1995

Expiration Date: N/A

Need for Headquarters' Action

(for permit renewals or new permits)
Yes ( ) No (X)

If yes, HQ Program Element

Brief Summary of Relevant Information (major permit conditions, status of compliance or unusual problems):

The Radon Research Facility originally was permitted to be installed in the 331 Building, Life Sciences Laboratory. Radon research involves the evaluation of worker and public health and safety issues related to radon in the work place and the environment. Because of program changes, a request was made to the Department of Health to relocate the radon research facility to an undetermined location within the 300 Area. The Department of Health approved the relocation pending the potential-to-emit did not affect the NESHAP status of the building, and all controls, or equivalent, committed to in the original Notice of Construction were installed. The Radon Research Facility has been moved to the 325 Building.

Compiled by: Pacific Northwest National Laboratory

Date: July 31, 1997

Environmental Protection 
DOE Operations Office: Richland

DOE Facility: Hanford Site

Existing Permit (X) Renewal ( ) New Permit ( )

Permit Type: National Emission Standard for Hazardous Air Pollutants (NESHAPs) 40 CFR 61, Subpart H

Permitting Agency: U.S. Environmental Protection Agency, Region 10.

Permit Number: N/A

Permitted Unit: Radon Research Facility, 331 Building

Issuance Date: August 8, 1995

Expiration Date: N/A

Need for Headquarters' Action

(for permit renewals or new permits)
Yes ( ) No ( $\mathrm{X}$ )

If yes, HQ Program Element

Brief Summary of Relevant Information (major permit conditions, status of compliance or unusual problems):

Radon research involves the evaluation or worker and public health and safety issues related to radon in the work place and the environment. The application was approved on August 8, 1995. The Radon Research Facility is located in the 325 Building.

Compiled by: Pacific Northwest National Laboratory

Date: July 31, 1997

Environmental Protection 
DOE Operations Office: Richland

DOE Facility: Hanford Site

Existing Permit (X) Renewal ( ) New Permit ( )

Permit Type: Radioactive Air Emissions Program Notice of Construction - WAC 246-247

Permitting Agency: Washington State Department of Health

Permit Number: Routine Technical Assistance Meeting

Permitted Unit: Radon Research Facility Relocation to Any Location Onsite

Issuance Date: May 1996

Expiration Date: NA

Need for Headquarters' Action

(for permit renewals or new permits)
Yes ( ) No (X).

If yes, HQ Program Element

Brief Summary of Relevant Information (major permit conditions, status of compliance or unusual problems):

Approval of this Notice of Construction allows the movement of the Radon Research Facility to any onsite location, in accordance with conditions contained in the Notice of Construction. The Department of Health determined that a formal Notice of Construction is not necessary unless the radioactive stack emissions are altered by the relocation. During the period covered by this Status Report, this activity proceeded with no compliance issues. The Radon Research Facility has been moved to the 325 Building.

Compiled by: Pacific Northwest National Laboratory Environmental Protection

Date: July 31, 1997 
DOE Operations Office: Richland

DOE Facility: Hanford Site

Existing Permit (X) Renewal ( ) New Permit ( )

Permit Type: Radioactive Air Emissions Program Notice of Construction - WAC 246-247

Permitting Agency: Washington State Department of Health

Permit Number: AIR-93-707

Permitted Unit: Rotary Mode Core-Sampling System Two

Issuance Date: July 8, 1993

Expiration Date: N/A

Need for Headquarters' Action

(for permit renewals or new permits)
Yes ( ) No ( $\mathrm{X}$ )

If yes, HQ Program Element

Brief Summary of Relevant Information (major permit conditions, status of compliance or unusual problems):

Approval of this Notice of Construction allows an exhauster to be installed on the passively ventilated double-shell and single-shell tanks containing hard saltcake. This installation allows rotary mode core sampling of the tank contents using approved radionuclide air emissions control equipment in accordance with descriptions contained in the Notice of Construction. Rotary mode core sampling in these tanks requires nitrogen to be injected into the tank. Therefore, the exhauster is required to prevent tank pressurization and to control emissions. The rotary mode core sampling activity is a Tri-Party Agreement Milestone (M-10-13).

Several revisions of the Notice of Construction have been submitted to the Department of Health. On January 11, 1995, the Department of Health approved increased hours of operation up to 24 hours a day. Also on January 1 1, 1995, the Department of Health approved the use of the in-riser prefilter as being optional. On July 17, 1996, the Department of Health approved the revised potential-to-emit. This action redesignated the Rotary Mode Core-Sampling System Exhauster Two to minor status; therefore, continuous emissions monitoring is not required--oniy periodic confirmatory measurements to verify low emissions. Future use of the Rotary Mode Core Sampling System in support of tank characterization activities is under review. The system is presently located at the 244-AR vault.

During the period covered by this Status Report, the Rotary Mode Core-Sampling System Two operated with no compliance issues

Compiled by: Waste Management Federal Services of Hanford, Inc. for Fluor Daniel Hanford, Inc.

Date: July 31, 1997 
DOE Operations Office: Richland

DOE Facility: Hanford Site

Existing Permit (X) Renewal ( ) New Permit ( )

Permit Type: National Emission Standard for Hazardous Air Pollutants (NESHAPs) 40 CFR 61, Subpart H

Permitting Agency: U.S. Environmental Protection Agency, Region 10

Permit Number: N/A

Permitted Unit: Rotary Mode Core Sampling System Two

Issuance Date: August 9, 1993

Expiration Date: N/A

Need for Headquarters' Action

(for permit renewals or new permits)
Yes ( ) No (X)

If yes, HQ Program Element

Brief Summary of Relevant Information (major permit conditions, status of compliance or unusual problems):

Approval of this application allows an exhauster to be installed on the passively ventilated double-shell and single-shell tanks containing hard saltcake. This installation allows rotary mode core sampling of the tank contents using approved radionuclide air emissions control equipment in accordance with descriptions contained in the application. Rotary mode core sampling in these tanks requires nitrogen to be injected into the tank. Therefore, the exhauster is required to prevent tank pressurization and to control emissions. The rotary mode core sampling activity is a Tri-Party Agreement Milestone (M-10-13). Use of this system to support tank characterization is under review.

During the period covered by this Status Report, the Rotary Mode Core-Sampling System Two Stack operated with no compliance issues.

Compiled by: Waste Management Federal Services of Hanford, Inc.

Date: July 31, 1997 for Fluor Daniel Hanford, Inc 
DOE Operations Office: Richland

DOE Facility: Hanford Site

Existing Permit (X) Renewal ( ) New Permit ( )

Permit Type: Controls for New Sources of Toxic Air Pollutants - WAC 173-460

Permitting Agency: Washington State Department of Ecology

Permit Number: NWP 95-RMCS(3)

Permitted Unit: Rotary Mode Core Sampling System Two

Issuance Date: June 30, 1995

Expiration Date: N/A

Need for Headquarters' Action

(for permit renewals or new permits)

Yes ( ) No (X)

If yes, HQ Program Element

Brief Summary of Relevant Information (major permit conditions, status of compliance or unusual problems):

Approval of this Notice of Construction allows an exhauster to be installed on the passively ventilated double-shell and single-shell tanks containing hard saltcake. This installation allows rotary mode core sampling of the tank contents in accordance with descriptions contained in the Notice of Construction. Rotary mode core sampling in these tanks requires nitrogen to be injected into the tank. Therefore, the exhauster is required to prevent tank pressurization and to control emissions. The rotary mode core sampling is a Tri-Party Agreement Milestone (M-10-13). Ecology reissued this permit on June 30,1995. The permit now covers Rotary Mode Core Sampling Systems Two, Three, and Four. Future use of the Rotary Mode Core Sampling System in support of tank characterization activities is under review. The system is presently located at the 244-AR vault.

During the period covered by this Status Report, the Rotary Mode Core Sampling System Two operated with no compliance issues.

Compiled by: Waste Management Federal Services of Hanford, Inc.

Date: July 31, 1997 for Fluor Daniel Hanford, Inc. 
DOE Operations Office: Richland

DOE Facility: Hanford Site

Existing Permit (X) Renewal ( ) New Permit ( )

Permit Type: Radioactive Air Emissions Program Notice of Construction - WAC 246-247

Permitting Agency: Washington State Department of Health

Permit Number: AIR-95-603

Permitted Unit: Rotary Mode Core-Sampling Systems Three and Four

Issuance Date: June 30, 1995

Expiration Date: N/A

Need for Headquarters' Action

(for permit renewals or new permits)

Yes ( ) No (X)

If yes, HQ Program Element

Brief Summary of Relevant Information (major permit conditions, status of compliance or unusual problems):

Approval of this Notice of Construction allows an exhauster to be installed on the passively ventilated double-shell and single-shell tanks containing hard saltcake. This installation allows rotary mode core sampling of the tank contents using approved radionuclide air emissions control equipment in accordance with descriptions contained in the Notice of Construction. Rotary mode core sampling in these tanks requires nitrogen to be injected into the tank. Therefore, the exhauster is required to prevent tank pressurization and to control emissions. The rotary mode core sampling activity is a Tri-Party Agreement Milestone (M-10-13).

Several revisions of the Notice of Construction have been submitted to and approved by the Department of Health. On July 17, 1996, the Department of Health approved the revised potential-to-emit. This action redesignated the Rotary Mode Core-Sampling System Exhausters Three and Four to minor status; therefore, continuous emissions monitoring is not required--only periodic confirmatory measurements to verify low emissions. The status of the exhausters is under review and may be changed to major status.

During the period covered by this Status Report, the Rotary Mode Core-Sampling Systems Three and Four Stacks operated with no compliance issues.

Compiled by: Waste Management Federal Services of Hanford, Inc. Date: July 31, 1997 for Fluor Daniel Hanford, Inc. 
DOE Operations Office: Richland

DOE Facility: Hanford Site

Existing Permit (X) Renewal ( ) New Permit ( )

Permit Type: National Emission Standard for Hazardous Air Pollutants (NESHAPs) 40 CFR 61, Subpart H

Permitting Agency: U.S. Environmental Protection Agency, Region 10

Permit Number: N/A

Permitted Unit: Rotary Mode Core Sampling Systems Three and Four

Issuance Date: June 11, 1995

Expiration Date: N/A

Need for Headquarters' Action

(for permit renewals or new permits)
Yes ( ) No (X)

If yes, HQ Program Element

Brief Summary of Relevant Information (major permit conditions, status of compliance or unusual problems):

Approval of this application allows an exhauster to be installed on the passively ventilated double-shell and single-shell tanks containing hard saltcake. This installation allows sampling of the tank contents using approved radionuclide air emissions control equipment in accordance with descriptions contained in the application. Rotary mode core sampling in these tanks requires nitrogen to be injected into the tank. Therefore. the exhauster is required to prevent tank pressurization and to control emissions. The rotary mode core sampling activity is a Tri-Party Agreement Milestone (M-10-13). A revised Application to Construct was submitted and awaits approval:

During the period covered by this Status Report, the Rotary Mode Core-Sampling Systems Three and Four operated with no compliance issues.

Compiled by: Waste Management Federal Services of Hanford, Inc.

Date: July 31, 1997 for Fluor Daniel Hanford, Inc. 
DOE Operations Office: Richland

DOE Facility: Hanford Site

Existing Permit (X ) Renewal ( ) New Permit ( )

Permit Type: Controls for New Sources of Toxic Air Pollutants - WAC 173-460

Permitting Agency: Washington State Department of Ecology

Permit Number: NWP-95RMCS(3)

Permitted Unit: Rotary Mode Core Sampling Systems Three and Four, and Modification of Rotary Mode Core Sampling System Two

Issuance Date: June 30, 1995

Expiration Date: N/A

Need for Headquarters' Action

(for permit renewals or new permits)
Yes ( ) No (X)

If yes, HQ Program Element

Brief Summary of Relevant Information (major permit conditions, status of compliance or unusual problems):

Approval of this Notice of Construction allows an exhauster to be installed on the passively ventilated double-shell and single-shell tanks containing hard saltcake. This installation allows sampling of the tank contents using approved nonradionuclide air emissions control equipment in accordance with descriptions contained in the Notice of Construction. Rotary mode core sampling in these tanks requires nitrogen to be injected into the tank. Therefore, the exhauster is required to prevent tank pressurization and to control emissions. The rotary mode core sampling activity is a Tri-Party Agreement Milestone (M-10-13).

The major permit conditions are: opacity from the stack will not exceed 5 percent; vapor analysis of the tanks head space will be conducted before rotary mode core sampling, if results are above any small quantity emission rate the tank cannot be rotary mode core sampled; volatile organic compound emissions at the stack will not exceed 3 pounds per day; and the sampling will be stopped if the gaseous flow through the high-efficiency particulate air filters has more than 80 percent relative humidity at any time.

During the period covered by this Status Report, the Rotary Mode Core-Sampling Systems Two, Three, and Four operated with no compliance issues.

Compiled by: Waste Management Federal Services of Hanford, Inc.

Date: July 31, 1997 for Fluor Daniel Hanford, Inc. 
DOE Operations Office: Richland

DOE Facility: Hanford Site

Existing Permit ( ) $\quad$ Renewal ( ) New Permit (X)

Permit Type: Radioactive Air Emissions Program Notice of Construction — WAC 246-247

Permitting Agency: Washington State Department of Health

Permit Number: Routine Technical Assistance Meeting

Permitted Unit: Routine, Exempt and Approved Tank Farm Activities

Issuance Date: January 9, 1996

Expiration Date: NA

Need for Headquarters' Action

(for permit renewals or new permits)
Yes ( ) No (X)

If yes, HQ Program Element

Brief Summary of Relevant Information (major permit conditions, status of compliance or unusual problems):

Approval of the "Routine, Exempt and Approved Tank Farm Activities" allows the listed activities to be conducted without prior approval from the Department of Health. Controls for protecting the air pathway are included with each activity and must be adhered to during the activity. The original list was approved on April 1, 1993.

The list was modified in Revision.1 (October 10, 1995) to combine all other categorical/routine type approved activities into one list; to add three new categories to the list--pit decontamination, size reduction of waste equipment, and removal of contaminated tank equipment; and to regroup the existing characterization activities into one category and add two more (use of the cone penetrometer and the surface moisture measurement system).

The list was modified in Revision 2 (January 9, 1996) to include characterization and stabilization verification activities for the inactive miscellaneous underground storage tanks.

During the period covered by this Status Report, the listed activities have taken place with no compliance issues.

Compiled by: Waste Management Federal Services of Hanford, Inc. for Fluor Daniel Hanford, Inc.

Date: July 31, 1997 
DOE Operations Office: Richland

DOE Facility: Hanford Site

Existing Permit ( ) Renewal ( ) Néw Permit (X)

Permit Type: Radioactive Air Emissions Program Notice of Construction — WAC 246-247

Permitting Agency: Washington State Department of Health

Permit Number:

Permitted Unit: Single-Shell Tanks Portable Exhauster for Salt Well Pumping and Other Activities (Minor Emission Point)

Issuance Date:

Expiration Date:

Need for Headquarters' Action

(for permit renewals or new permits)
Yes ( ) No (X)

If yes, HQ Program Element

Brief Summary of Relevant Information (major permit conditions, status of compliance or unusual problems):

Approval of this Notice of Construction will allow for the operation of portable exhausters on singleshell tanks, in accordance with descriptions in the Notice of Construction, during salt well pumping and other routine activities.

Compiled by: Waste Management Federal Services of Hanford, Inc.

Date: July 31, 1997 for Fluor Daniel Hanford, Inc. 
DOE Operations Office: Richland

DOE Facility: Hanford Site

Existing Permit ( ) Renewal ( ) New Permit (X)

Permit Type: National Emission Standard for Hazardous Air Pollutants (NESHAPs) 40 CFR 6l, Subpart H

Permitting Agency: U.S. Environmental Protection Agency, Region 10

Permit Number: N/A

Permitted Unit: Single-Shell Tanks Portable Exhauster for Salt Well Pumping and Other Activities (Minor Emission Point)

Issuance Date: July 17, 1997

Expiration Date: N/A

Need for Headquarters' Action

(for permit renewals or new permits)
Yes ( ) No (X)

If yes, HQ Program Element

Brief Summary of Relevant Information (major permit conditions, status of compliance or unusual problems):

Approval of this application allows for the operation of portable exhausters on single-shell tanks, in accordance with descriptions in the application, during salt well pumping and other routine type activities.

During the period covered by this Status Report, no portable exhausters described in the application have been in operation.

Compiled by: Waste Management Federal Services of Hanford, Inc.

Date: July 31, 1997 for Fluor Daniel Hanford, Inc. 
DOE Operations Office: Richland

DOE Facility: Hanford Site

Existing Permit ( ) Renewal ( ) New Permit (X)

Permit Type: Controls for New Sources of Toxic Air Pollutants - WAC 173-460

Permitting Agency: Washington State Department of Ecology

Permit Number: TBD

Permitted Unit: Single-Shell Tanks Portable Exhauster for Salt Well Pumping and Other Activities

Issuance Date: TBD

Expiration Date:

Need for Headquarters' Action

(for permit renewals or new permits)
Yes ( ) No (X)

If yes, HQ Program Element

Brief Summary of Relevant Information (major permit conditions, status of compliance or unusual problems):

Approval of this Notice of Construction will allow for the operation of portable exhausters on singleshell tanks, in accordance with descriptions in the Notice of Construction, during salt well pumping and other routine activities.

Compiled by: Waste Management Federal Services of Hanford, Inc.

Date: July 31, 1997 for Fluor Daniel Hanford, Inc. 
DOE Operations Office: Richland

DOE Facility: Hanford Site

Existing Permit (X) $\quad$ Renewal ( ) New Permit ( )

Permit Type: Radioactive Air Emissions Program Notice of Construction - WAC 246-247

Permitting Agency: Washington State Department of Health

Permit Number: AIR 95-204

Permitted Unit: Sodium Storage Facility, Project F-031

Issuance Date: February 24, 1995

Expiration Date: N/A

Need for Headquarters' Action

(for permit renewals or new permits)
Yes ( ) No (X)

If yes, HQ Program Element

Brief Summary of Relevant Information (major permit conditions, status of compliance or unusual problems):

Approval of this Notice of Construction allows construction of the Sodium Storage Facility (Project F-031) in accordance with descriptions contained in the application. The Sodium Storage Facility supports the sodium offload from the Fast Flux Test Facility during transition to decommissioning. The Sodium Storage Facility receives molten sodium coolant from the Fast Flux Test Facility, stores the sodium in a solid state for an extended period, and melts the sodium for transfer to a future Sodium Reaction Facility. Approval of the Notice of Construction was granted with the understanding that the technology standards identified during the definitive design process would be submitted to the Department of Health when available. along with the associated costs of construction. Subsequently, the technology standards were submitted August 8. 1995, and the costs of construction were submitted August 22. 1995. Construction of the facility was completed in October 1996. Currently the tanks and piping are inerted with argon. Layup activities are beginning that would allow the facility to be locked requiring only minimal surveillance and maintenance while the Fast Flux Test Facility remains in standby awaiting a decision regarding future operation.

During the period covered by this Status Report. this project proceeded with no compliance issues.

Compiled by: Waste Management Federal Services of Hanford, Inc. for Fluor Daniel Hanford, Inc.

Date: July 31, 1997 
DOE Operations Office: Richland

DOE Facility: Hanford Site

Existing Permit (X) Renewal ( ) New Permit ( )

Permit Type: National Emission Standard for Hazardous Air Pollutants (NESHAPs) 40 CFR 61, Subpart H

Permitting Agency: U.S. Environmental Protection Agency, Region 10

Permit Number: N/A

Permitted Unit: Sodium Storage Facility, Project F-031

Issuance Date: February 8, 1995

Expiration Date: N/A

Need for Headquarters' Action

(for permit renewals or new permits)
Yes ( ) No (X)

If yes, HQ Program Element

Brief Summary of Relevant Information (major permit conditions, status of compliance or unusual problems):

This approved application allows for construction of the Sodium Storage Facility (Project F-031) in accordance with descriptions contained in the application. The Sodium Storage Facility supports the sodium offload from the Fast Flux Test Facility during transition to decommissioning. The Sodium Storage Facility receives molten sodium coolant from the Fast Flux Test Facility, stores the sodium in a solid state for an extended period, and melts the sodium for transfer to a future Sodium Reaction Facility. Construction was completed in October 1996. Currently the tanks and piping are inerted with argon. Layup activities are beginning that would allow the facility to be locked requiring only minimal surveillance and maintenance while the Fast Flux Test Facility remains in standby awaiting a decision regarding future operation.

Approval of this application to construct allows for sodium offloading at the Fast Flux Test Facility.

Compiled by: Waste Management Federal Services of Hanford, Inc.

Date: July 31, 1997 for Fluor Daniel Hanford, Inc. 
DOE Operations Office: Richland

DOE Facility: Hanford Site

Existing Permit ( ) Renewal ( ) New Permit (X)

Permit Type: Radioactive Air Emissions Program Notice of Construction - WAC 246-247

Permitting Agency: Washington State Department of Health

Permit Number: (97-EAP-050)?

Permitted Unit: Stabilization of Plutonium Metal Oxides in Muffle Furnaces at the Plutonium Finishing Plant

Issuance Date: December 18, 1996

Expiration Date: N/A

Need for Headquarters' Action (for permit renewals or new permits)

Yes ( ) No (X)

If yes, HQ Program Element

Brief Summary of Relevant Information (major permit conditions, status of compliance or unusual problems):

Approval of this Notice of Construction allows for the thermal stabilization of plutonium metals and oxides in the muffle furnaces at the Plutonium Finishing Plant.

Compiled by: Waste Management Federal Services of Hanford, Inc.

Date: July 31, 1997 for Fluor Daniel Hanford, Inc. 
DOE Operations Office: Richland

DOE Facility: Hanford Site

Existing Permit ( ) Renewal ( ) New Permit (X)

Permit Type: National Emission Standard for Hazardous Air Pollutants (NESHAPs) 40 CFR 61, Subpart H

Permitting Agency: U.S. Environmental Protection Agency, Region 10

Permit Number: 97-EAP-050

Permitted Unit: Stabilization of Plutonium Metal Oxides in Muffle Furnaces at the Plutonium Finishing Plant

Issuance Date: February December 18, 1997

Expiration Date: N/A

Need for Headquarters' Action

(for permit renewals or new permits)
Yes ( ) No (X)

If yes, HQ Program Element

Brief Summary of Relevant Information (major permit conditions, status of compliance or unusual problems):

This approved application allows for the thermal stabilization of plutonium metals and oxides in the muffle furnaces at the Plutonium Finishing Plant.

Compiled by: Waste Management Federal Services of Hanford, Inc.

Date: July 31,1997 for Fluor Daniel Hanford, Inc. 
DOE Operations Office: Richland

DOE Facility: Hanford Site

Existing Permit ( $\mathrm{X}$ ) Renewal ( ) New Permit ( )

Permit Type: Radioactive Air Emissions Program Notice of Construction - WAC 246-247

Permitting Agency: Washington State Department of Health

Permit Number: AIR-94-404

Permitted Unit: Stabilization of the 105-N Basin

Issuance Date; April 11, 1994

Expiration Date: N/A

Need for Headquarters' Action

(for permit renewals or new permits)
Yes ( ) No ( $X)$

If yes, HQ Program Element

Brief Summary of Relevant Information (major permit conditions, status of compliance or unusual problems):

Approval of this Notice of Construction allows stabilization activities to commence at the 105- $\mathrm{N}$ Basin in the 100-N Area using approved radionuclide air emissions control equipment. Stabilization activities include work in preparation for final decontamination and decommissioning of the basin. Approval was received from the Department of Health on April 11, 1994. The 105-N Basin stabilization activities began on May 30,1995, and work is in progress.

Compiled by: Bechtel Hanford, Inc.

Date: July 31 , 1997

Regulatory Support 
DOE Operations Office: Richland

DOE Facility: Hanford Site

Existing Permit (X) Renewal ( ) New Permit ( )

Permit Type: National Emission.Standard for Hazardous Air Pollutants (NESHAPs) 40 CFR 61, Subpart H

Permitting Agency: U.S. Environmental Protection Agency, Region 10

Permit Number: N/A

Permitted Unit: Stabilization of the 105-N Basin

Issuance Date: May 10, 1994

Expiration Date: N/A

Need for Headquarters' Action

(for permit renewals or new permits)
Yes ( ) No ( $\mathrm{X}$ )

If yes, HQ Program Element

Brief Summary of Relevant Information (major permit conditions, status of compliance or unusual problems):

Approval of this application allows stabilization activities to commence at the $105-\mathrm{N}$ Basin in the 100-N Area using approved radionuclide air emissions control equipment. Stabilization activities include work in preparation for final decontamination and decommissioning of the basin. Approval was received from the EPA on May 10, 1994. The 105-N Basin stabilization activities began on May 30,1995 , and work is in progress.

Compiled by: Bechtel Hanford, Inc.

Date: July 31, 1997

Regulatory Support 
DOE Operations Office: Richland

DOE Facility: Hanford Site

Existing Permit (X) Renewal ( ) New Permit ( )

Permit Type: Notice of Construction for:

General Regulations for Air Pollution Sources - WAC 173-400

Controls for New Sources of Toxic Air Pollutants - WAC 173-460

Permitting Agency: Washington State Department of Ecology

Permit Number: NOC-94-064 and NOC-94-06A

Permitted Unit: Steam Plant Rehabilitation, Phase II, Project L-017

Issuance Date: October 18, 1994 and May 3 I, 1994

Expiration Date: N/A

Need for Headquarters' Action

(for permit renewals or new permits)
Yes ( ) No (X)

If yes, HQ Program Element

Brief Summary of Relevant Information (major permit conditionș, status of compliance or unusual problems):

Approval of this Notice of Construction allows construction of the standalone oil-fired package boiler in the 200 West Area. The backup boiler provides up to 18.662 kilograms per hour of steam. The boiler is intended to be brought on-line only in an event where demands exceed production of the coal-fired boilers, or because the steam-tie line is out of service. Major permit conditions include limits on hours of operation and emission rates.

During the period covered by this Status Report, the Steam Plant operated with no compliance issues.

Compiled by: Waste Management Federal Services of Hanford, Inc.

Date: July 31, 1997 for Fluor Daniel Hanford, Inc. 
DOE Operations Office: Richland

DOE Facility: Hanford Site

Existing Permit (X) Renewal ( ) New Permit ()

Permit Type: Radioactive Air Emissions Program Notice of Construction - WAC 246-247

Permitting Agency: Washington State Department of Health

Permit Number: N/A

Permitted Unit: Storage of the Liquid Waste Tank Cars and the 324 Building Waste in the PUREX Storage Tunnel Number 2

Issuance Date: June 7, 1996

Expiration Date: N/A

Need for Headquarters' Action

(for permit renewals or new permits)
Yes ( ) No (X)

If yes, HQ Program Element

Brief Summary of Relevant Information (major permit conditions, status of compliance or unusual problems):

Approval of this Notice of Construction allows the transfer and storage of up to four liquid waste tank cars and waste from the 324 Building to the PUREX Storage Tunnel Number 2 in accordance with descriptions contained in the Notice of Construction.

During the period covered by this Status Report, this activity proceeded with no compliance issues.

Compiled by: Waste Management Federal Services of Hanford, Inc.

Date: July 31, 1997 for Fluor Daniel Hanford, Inc. 
DOE Operations Office: Richland

DOE Facility: Hanford Site

Existing Permit $(\mathrm{X})$

Renewal ( )

New Permit 0

Permit Type: National Emission Standard for Hazardous Air Pollutants (NESHAPs) 40 CFR 61, Subpart $H$

Permitting Agency: $\quad$ U.S. Environmental Protection Agency, Region 10

Permit Number: N/A

Permitted Unit: Storage of the Liquid Waste Tank Cars and the 324 Building Waste in the PUREX Storage Tunnel Number 2

Issuance Date: May 28, 1996

Expiration Date: N/A

Need for Headquarters' Action

Yes ( ) No (X)

(for permit renewals or new permits)

If yes, HQ Program Element

Brief Summary of Relevant Information (major permit conditions, status of compliance or unusual problems):

Approval of this application allows for the transfer and storage of up to four liquid waste tank cars and waste from the 324 Building to the PUREX Storage Tunnel Number 2 in accordance with descriptions contained in the application.

During the period covered by this Status Report, this activity proceeded with no compliance issues

Compiled by: Waste Management Federal Services of Hanford, Inc.

Date: July 31, 1997

for Fluor Daniel Hanford, Inc. 
DOE Operations Office: Richland

DOE Facility: Hanford Site

Existing Permit (X) Renewal ( ) New Permit ( )

Permit Type: Radioactive Air Emissions Program Notice of Construction - WAC 246-247

Permitting Agency: Washington State Department of Health

Permit Number: Routine Technical Assistance Meeting

Permitted Unit: T Plant Complex Secondary Containment and Leak Detection Upgrades, Project W-259

Issuance Date: June 1996

Expiration Date: NA

Need for Headquarters' Action

(for permit renewals or new permits)
Yes ( ) No (X)

If yes, HQ Program Element

Brief Summary of Relevant Information (major permit conditions, status of compliance or unusual problems):

Approval of this Notice of Construction allows secondary containment and leak detection upgrades to be initiated at $T$ Plant Complex. The results of the non-destructive assessment of the 2706- $T$ high-efficiency particulate air filter bank confirmed that the associated stack represented a nondesignated stack $(<0.1$ millirem per year potential-to-emit).

During the period covered by this Status Report, this activity proceeded with no compliance issues.

Compiled by: Waste Management Federal Services of Hanford, Inc.

Date: July 31,1997 for Fluor Daniel Hanford, Inc. 
DOE Operations Office: Richland

DOE Facility: Hanford Site

Existing Permit ( ) $\quad$ Renewal ( ) New Permit (X)

Permit Type: National Emission Standard for Hazardous Air Pollutants (NESHAPs) 40 CFR 61, Subpart H

Permitting Agency: U.S. Environmental Protection Agency, Region 10

Permit Number: N/A

Permitted Unit: T Plant Complex Secondary Containment and Leak Detection Upgrades, Project W-259

Issuance Date: September 1996

Expiration Date: N/A

Need for Headquarters' Action

(for permit renewals or new permits)
Yes ( ) No (X)

If yes, HQ Program Element

Brief Summary of Relevant Information (major permit conditions, status of compliance or unusual problems):

Approval of this application allows secondary containment and leak detection upgrades to be initiated at $T$ Plant Complex. The results of the nondestructive assessment of the 2706-T high-efficiency particulate air filter bank confirmed that the associated stack represented a nondesignated stack $(<0.1$ millirem per year potential-to-emit $)$.

During the period covered by this Status Report, this activity proceeded with no compliance issues.

Compiled by: Waste Management Federal Services of Hanford, Inc.

Date: July 31, 1997 for Fluor Daniel Hanford, Inc. 
DOE Operations Office: Richland

DOE Facility: Hanford Site

Existing Permit ( ) Renewal ( ) New Permit (X)

Permit Type: Radioactive Air Emissions Program Notice of Construction - WAC 246-247

Permitting Agency: Washington State Department of Health

Permit Number: Routine Technical Assistance Meeting

Permitted Unit: T Plant Complex--Euroclean ${ }^{1}$ HEPA-filtered vacuums to be used for contamination control and in waste handling activities

Issuance Date: December 10, 1996

Expiration Date: N/A

Need for Headquarters' Action

Yes ( ) No (X)

(for permit renewals or new permits)

If yes, HQ Program Element

Brief Summary of Relevant Information (major permit conditions, status of compliance or unusual problems):

Approval of this Notice of Construction allows use of three Euroclean vacuums for contamination control, spill cleanup, zone reduction, and waste handling activities. The vacuums are controlled to limit emissions. Also, the use of the vacuums is recorded daily on logs, and the logs are used to determine potential annual emissions. There was an inspection by the Washington Department of Health during the period covered by this status report, and no significant compliance issues were identified.

${ }^{\mathrm{I} E u r o c l e a n}$ is a trademark. System manufactured by Sweden Corporation of Sweden.

Compiled by: Waste Management Federal Services of Hanford, Inc.

Date: July 31, 1997 for Fluor Daniel Hanford, Inc. 
DOE Operations Office: Richland

DOE Facility: Hanford Site

Existing Permit (X) Renewal ( ) New Permit ( )

Permit Type: Radioactive Air Emissions Program Notice of Construction - WAC 246-247

Permitting Agency: Washington State Department of Health

Permit Number: N/A

Permitted Unit: Transfer and Receipt of Waste in the 324 Building for Storage in PUREX Storage Tunnel Number 2

Issuance Date: December 4, 1995

Expiration Date: N/A

Need for Headquarters' Action

(for permit renewals or new permits)
Yes ( ) No (X)

If yes, HQ Program Element

Brief Summary of Relevant Information (major permit conditions, status of compliance or unusual problems):

Approval of this Notice of Construction allows activities to proceed to safely containerize, transport, and store waste from the 324 Building in the PUREX Storage Tunnel Number 2 in accordance with descriptions contained in the Notice of Construction.

During the period covered by this Status Report, this activity proceeded with no compliance issues.

Compiled by: Waste Management Federal Services of Hanford, Inc

Date: July 31, 1997

for Fluor Daniel Hanford, Inc. 
DOE Operations Office: Richland

DOE Facility: Hanford Site

Existing Permit (X) Renewal ( ) New Permit ( )

Permit Type: National Emission Standard for Hazardous Air Pollutants (NESHAPs) 40 CFR 61, Subpart H

Permitting Agency: U.S. Environmental Protection Agency, Region 10

Permit Number: N/A

Permitted Unit: Transfer and Receipt of Waste in the 324 Building for Storage in PUREX Storage Tunnel Number 2

Issuance Date: December 6, 1995

Expiration Date: N/A

Need for Headquarters' Action

(for permit renewals or new permits)
Yes ( ) No (X)

If yes, HQ Program Element

Brief Summary of Relevant Information (major permit conditions, status of compliance or unusual problems):

Approval of this application allows activities to proceed to safely containerize, transport, and store waste from the 324 Building in the PUREX Storage Tunnel Number 2 in accordance with descriptions contained in the application.

During the period covered by this Status Report, this activity proceeded with no compliance issues.

Compiled by: Waste Management Federal Services of Hanford, Inc.

Date: July 31, 1997 for Fluor Daniel Hanford, Inc. 
DOE Operations Office: Richland

DOE Facility: Hanford Site

Existing Permit ( ) Renewal ( ) New Permit (X)

Permit Type: Radioactive Air Emission Program Notice of Construction - WAC 246-247

Permitting Agency: Washington State Department of Health

Permit Number:

Permitted Unit: Vertical Calciner at Plutonium Finishing Plant

Issuance Date: July 1996 WDOH Approval: November 8, 1996

EPA Approval: $\quad$ October 3, 1996

Expiration Date: N/A

Need for Headquarters' Action

(for permit renewals or new permits)

Yes ( ) No (X).

If yes, $\mathrm{HQ}$ Program Element

Brief Summary of Relevant Information (major permit conditions, status of compliance or unusual problems):

Approval of this Notice of Construction allows the construction, installation, and operation of the vertical calciner at 234-5Z Building. The plutonium and transuranic solutions will be stabilized to a plutonium oxide. Once this meets the DOE Order 3013 requirement for long-term storage, the materials will be placed in the PFP vaults. The vertical calciner also is discussed in the Plutonium Finishing Plant environmental impact statement.

Compiled by: Waste Management Federal Services of Hanford, Inc.

Date: July 31, 1997 for Fluor Daniel Hanford, Inc. 
DOE Operations Office: Richland

DOE Facility: Hanford Site

Existing Permit ( ) Renewal ( ) New Permit (X)

Permit Type: Radioactive Air Emissions Program Notice of Construction - WAC 246-247

Permitting Agency: Washington State Department of Health/U.S. Environmental Protection Agency

Permit Number: Routine Technical Assistance Meeting

Permitted Unit: Waste Encapsulation and Storage Facility K-3 Duct Characterization

Issuance Date: November 12, 1996 (Washington State Department of Health)

December 20, 1996 (U.S. Environmental Protection Agency)

Expiration Date:

Need for Headquarters' Action

Yes ( ) No (X)

(for permit renewals or new permits)

If yes, HQ Program Element

Brief Summary of Relevant Information (major permit conditions, status of compliance or unusual problems):

The approval allows for a change in a previous approval to perform K-3 duct characterization work. The new activity involves use of the FLUTE ${ }^{1}$ Technology. The FLUTE Technology will be used to obtain smears from inside the K-3 duct. Also, a camera with an R-07 probe will be used to photograph the duct and obtain radiation readings.

\footnotetext{
${ }^{1}$ FLUTE is a trademark.
}

Compiled by: Waste Management Federal Services of Hanford, Inc.

Date: July 31, 1997 for Fluor Daniel Hanford, Inc. 
DOE Operations Office: Richland

DOE Facility: Hanford Site

Existing Permit (X) Renewal ( ) New Permit ( )

Permit Type: Radioactive Air Emissions Program Notice of Construction - WAC 246-247

Permitting Agency: Washington State Department of Health

Permit Number: AIR-93-907

Permitted Unit: Waste Receiving and Processing Facility

Issuance Date: September 7, 1993

Expiration Date: Expires if work is interrupted for $>18$ months

Need for Headquarters' Action

(for permit renewals or new permits)
Yes ( ) No ( $\mathrm{X}$ )

If yes, HQ Program Element

Brief Summary of Relevant Information (major permit conditions, status of compliance or unusual problems):

Approval of this Notice of Construction allows construction of Waste Receiving and Processing Facility using approved radionuclide air emissions control equipment (Tri-Party Agreement Milestones M-18-00 and M-18-01). Waste Receiving and Processing Facility is permitted to examine, assay, characterize, treat, and repackage radioactive and mixed waste.

During the period covered by this Status Report, Waste Receiving and Processing Facility activities proceeded with no compliance issues.

Compiled by: Waste Management Federal Services of Hanford, Inc.

Date: July 31, 1997 for Fluor Daniel Hanford, Inc. 
DOE Operations Office: Richland

DOE Facility: Hanford Site

Existing Permit (X) Renewal ( ) New Permit ( )

Permit Type: National Emission Standards for Hazardous Air Pollutants (NESHAPs) 40 CFR 61, Subpart H

Permitting Agency: U.S. Environmental Protection Agency, Region 10

Permit Number: N/A

Permitted Unit: Waste Receiving and Processing Facility

Issuance Date: May 10, 1993

Expiration Date: Expires if work is interrupted for $>18$ months

Need for Headquarters' Action

(for permit renewals or new permits)
Yes ( ) No (X)

If yes, HQ Program Element

Brief Summary of Relevant Information (major permit conditions, status of compliance or unusual problems):

Approval of this application allows construction of Waste Receiving and Processing Facility using approved radionuclide air emissions control equipment (Tri-Party Agreement Milestones M-18-00 and M-18-01). The Waste Receiving and Processing Facility is permitted to examine, assay, characterize, treat, and repackage radioactive and mixed waste.

During the period covered by this Status Report, these Waste Receiving and Processing Facility activities proceeded with no compliance issues.

Compiled by: Waste Management Federal Services of Hanford, Inc. for Fluor Daniel Hanford, Inc.

Date: July 31, 1997 
DOE Operations Office: Richland

DOE Facility: Hanford Site

Existing Permit (X) Renewal ( ) New Permit ( )

Permit Type: Notice of Construction for:

General Regulations for Air Pollution Sources - WAC 173-400

Controls for New Sources of Toxic Air Pollutants - WAC 173-460

Permitting Agency: Washington State Department of Ecology

Permit Number: NOC-93-05

Permitted Unit: Waste Receiving and Processing Facility

Issuance Date: December 19, 1993

Expiration Date: N/A

Need for Headquarters' Action

(for permit renewals or new permits)
Yes ( ) No (X)

If yes, HQ Program Element

Brief Summary of Relevant Information (major permit conditions, status of compliance or unusual problems):

Approval of this Notice of Construction allows construction of the Waste Receiving and Processing Facility using approved radionuclide air emissions control equipment (Tri-Party Agreement Milestones M-18-00 and M-18-01). The Waste Receiving and Processing Facility is permitted to examine, assay, characterize, treat, and repackage radioactive and mixed waste.

During the period covered by this Status Report, these Waste Receiving and Processing Facility activities proceeded with no compliance issues.

Compiled by: Waste Management Federal Services of Hanford, Inc.

Date: July 31, 1997 for Fluor Daniel Hanford, Inc. 
DOE Operations Office: Richland

DOE Facility: Hanford Site

Existing Permit (X) Renewal ( ) New Permit ( )

Permit Type: Radioactive Air Emissions Program Notice of Construction - WAC 246-247

Permitting Agency: Washington State Department of Health

Permit Number: Routine Technical Assistance Meeting

Permitted Unit: Waste Receiving and Processing Facility Stack No. 296-W-004 Monitoring System Modifications

Issuance Date: July 1996

Expiration Date: NA

Need for Headquarters' Action

(for permit renewals or new permits)
Yes ( ) No (X)

If yes, HQ Program Element

Brief Summary of Relevant Information (major permit conditions, status of compliance or unusual problems):

Approval of this Notice of Construction allows a revision to the Waste Receiving and Processing Facility effluent monitoring system. Instead of using two separate continuous air monitors, one will be used that will measure both alpha and beta emitting particles. Also, filter media will be changed reflecting a greater collection efficiency to $>99$ percent for 0.3 micron.

During the period covered by this Status Report, this change in the monitoring system proceeded with no compliance issues.

Compiled by: Waste Management Federal Services of Hanford, Inc.

Date: July 31, 1997 for Fluor Daniel Hanford, Inc. 
DOE Operations Office: Richland

DOE Facility: Hanford Site

Existing Permit (X) Renewal ( ) New Permit ( )

Permit Type: Radioactive Air Emissions Program Notice of Construction - WAC 246-247

Permitting Agency: Washington State Department of Health

Permit Number: EPS-90-275

Permitted Unit: Waste Sampling and Characterization Facility

Issuance Date: June 11, 1990

Expiration Date: N/A

Need for Headquarters' Action

(for permit renewals or new permits)

Yes ( ) No (X)

If yes, HQ Program Element

Brief Summary of Relevant Information (major permit conditions, status of compliance or unusual problems):

Approval of this Notice of Construction allows construction of the Waste Sampling and Characterization Facility in the 600 Area using approved radionuclide air emissions control equipment in accordance with descriptions contained in the application. The Waste Sampling and Characterization Facility provides the sample analyses necessary to support remediation on the Hanford Site. No revisions of this Notice of the Construction have been submitted to the Department of Health.

During the period covered by this Status Report, the Waste Sampling and Characterization Facility operated with no compliance issues.

Compiled by: Waste Management Federal Services of Hanford, Inc. for Fluor Daniel Hanford, Inc.

Date: July 31, 1997 
DOE Operations Office: Richland

DOE Facility: Hanford Site

Existing Permit (X) Renewal ( ) New Permit ( )

Permit Type: Notice of Construction for:

General Regulations for Air Pollution Sources - WAC 173-400

Controls for New Sources of Toxic Air Pollutants - WAC 173-460

Permitting Agency: Washington State Department of Ecology

Permit Number: N/A

Permitted Unit: Waste Sampling and Characterization Facility

Issuance Date: September 17, 1990

Expiration Date: N/A

Need for Headquarters' Action

(for permit renewals or new permits)
Yes ( ) No (X).

If yes, HQ Program Element

Brief Summary of Relevant Information (major permit conditions, status of compliance or unusual problems):

Approval of this Notice of Construction allows construction of the Waste Sampling and Characterization Facility in the 600 Area using approved nonradionuclide air emissions control equipment. The Waste Sampling and Characterization Facility provides the sample analyses necessary to support remediation on the Hanford Site. No revisions of the Notice of Construction have been submitted to Ecology. No approval conditions were specified.

During the period covered by this Status Report, the Waste Sampling and Characterization Facility operated with no compliance issues.

Compiled by: Waste Management Federal Services of Hanford, Inc.

Date: July 31,1997

for Fluor Daniel Hanford, Inc. 
DOE Operations Office: Richland

DOE Facility: Hanford Site

Existing Permit ( ) Renewal ( ) N New Permit (X)

Permit Type: Radioactive Air Emissions Program Notice of Construction - WAC 246-247

Permitting Agency: Washington State Department of Health

Permit Number: N/A

Permitted Unit: Water/Sediment Removal from 107-N, 1310-N, and 1314-N Facilities

Issuance Date: March 17, 1997

Expiration Date: N/A

Need for Headquarters' Action (for permit renewals or new permits)

Yes ( ) No (X)

If yes, HQ Program Element

Brief Summary of Relevant Information (major permit conditions, status of compliance or unusual problems):

Approval of this Notice of Construction allows for water/sediment removal from 107-N, 1310-N, and 1314-N Facilities. Approval was received from the Department of Health on March 17, 1997. Activities are scheduled to begin in July 1997.

Compiled by: Bechtel Hanford Inc.

Date: July 31, 1997

Reguiatory Support 
DOE Operations Office: Richland.

DOE Facility: Hanford Site

Existing Permit ( ) Renewal ( ) New Permit (X)

Permit Type: National Emission Standard for Hazardous Air Pollutants (NESHAPs) 40 CFR 61, Subpart H

Permitting Agency: U.S. Environmental Protection Agency, Region 10

Permit Number: N/A

Permitted Unit: Water/Sediment Removal from 107-N, 1310-N, and 1314-NFacilities

Issuance Date: May 30, 1997

Expiration Date: N/A

Need for Headquarters' Action

Yes ( ) No (X)

(for permit renewals or new permits)

If yes, HQ Program Element

Brief Summary of Relevant Information (major permit conditions, status of compliance or unusual problems):

Approval of this application allows for water/sediment removal from the 107-N, 1310-N, and 1314-N Facilities. Approval was received from the EPA on May 30, 1997. Activities began in July 1997.

Compiled by: Bechtel Hanford Inc.

Date: July 31,1997

Regulatory Support 
This page intentionally left blank. 
DOE/RL-96-63, Rev. 1

\section{CLEAN WATER ACT PERMITTING}


DOE/RL-96-63, Rev. 1

$10 / 97$

This page intentionally left blank. 
DOE Operations Office: Richland

DOE Facility: Hanford Site

Existing Permit (X) Renewal ( ) New Permit ( )

Permit Type: National Pollutant Discharge Elimination System (NPDES) - 40 CFR 122

Permitting Agency: U.S. Environmental Protection Agency, Region 10

Permit Number: WA-000374-3

Permitted Unit: 004A Outfall

Issuance Date: December 12, 1981

Expiration Date: Refer to Note

Need for Headquarters' Action

(for permit renewals or new permits)

Yes ( ) No (X)

If yes, HQ Program Element

Brief Summary of Relevant Information (major permit conditions, status of compliance or unusual problems):

The NPDES governs discharges to the Columbia River. The major permit conditions include discharge points, effluent limitations, and monitoring requirements.

The 100K Pools are planned for fish rearing by the Yakima Indian Nation. A letter was sent to the EPA on August 1, 1996, identifying topics to discuss on NPDES permitting.

Note: The Hanford Site NPDES Permit expired December 31, 1985. Part 4, Subsection D, "General Requirements of the Federal Water Pollution Control Act," provides for a continuation of the existing NPDES permit in force until the EPA acts upon subsequent applications for renewal or modification. A renewal application was submitted to the EPA on June 28,1985 . Another renewal application was forwarded to DOE-RL during July 1997 for subsequent transmittal to EPA under WA-002591-7 (300 Area Treated Effluent Disposal Facility).

Compiled by: Waste Management Federal Services of Hanford, Inc.

Date: July 31, 1997 for Fluor Daniel Hanford, Inc. 
DOE Operations Office: Richland

DOE Facility: Hanford Site

Existing Permit (X) Renewal ( ) New Permit ( )

Permit Type: National Pollutant Discharge Elimination System (NPDES) - 40 CFR 122

Permitting Agency: U.S. Environmental Protection Agency, Region 10

Permit Number: WA-000374-3

Permitted Unit: 013 A Outfall

Issuance Date: December 12, 1981

Expiration Date: Refer to Note

Need for Headquarters' Action

(for permit renewals or new permits)
Yes ( ) No (X)

If yes, HQ Program Element

Brief Summary of Relevant Information (major permit conditions, status of compliance or unusual problems):

The NPDES permit governs discharges to the Columbia River. The major permit conditions include discharge points, effluent limitations, and monitoring requirements.

The Hanford Site NPDES permit has been scheduled for revision by EPA Region 10 during CY 1997. This revision includes a proposal to combine the 300 Area Treated Effluent Disposal Facility NPDES permit (WA-002591-7) with the existing Hanford Site NPDES permit (thus. one Hanford Site NPDES would provide coverage for all process discharges to the Columbia River).

Note: The Hanford Site NPDES Permit expired December 31, 1985. Part 4, Subsection D, "General Requirements of the Federal Water Pollution Control Act." provides for a continuation of the existing NPDES permit in force until the EPA acts upon subsequent applications for renewal or modification. A renewal application was submitted to the EPA on June 28,1985 . A request for eliminating the outfall from the NPDES program was submitted to DOE-RL during July 1997 for subsequent transmittal to EPA. 
DOE Operations Office: Richland

DOE Facility: Hanford Site

Existing Permit (X) Renewal ( ) New Permit ( )

Permit Type: Modification Request for the Hanford Site National Pollutant Discharge Elimination System (NPDES) Permit - 40 CFR 122

Permitting Agency: U.S. Environmental Protection Agency, Region 10

Permit Number: WA-000374-3

Permitted Unit: $005,006,007,009$, and N Springs Outfalls

Issuance Date: December 12, 1981

Expiration Date: Refer to Note

Need for Headquarters' Action

(for permit renewals or new permits)

Yes ( ) No (X)

If yes, HQ Program Element

Brief Summary of Relevant Information (major permit conditions, status of compliance or unusual problems):

The NPDES governs discharges to the Columbia River. The major permit conditions include discharge points, effluent limitations, and monitoring requirements.

A request for minor modification to the NPDES permit to eliminate $005,006,007,009$, and $\mathrm{N}$ Springs Outfalls from the monitoring and reporting requirements was submitted to the EPA in August 1995. The outfalls are inactive.

Note: $\quad$ The Hanford Site NPDES Permit expired December 31, 1985. Part 4, Subsection $D$, "General Requirements of the Federal Water Pollution Control Act," provides for a continuation of the existing NPDES permit in force until the EPA acts upon subsequent applications for renewal or modification. A renewal application was submitted to the EPA on June 28, 1985. A followup request for eliminating the outfalls from the NPDES program was submitted to DOE-RL during July 1997 for subsequent transmittal to EPA.

Compiled by: Bechtel Hanford, Inc.

Date: July 31, 1997

Regulatory Support 
DOE Operations Office: Richland

DOE Facility: Hanford Site

Existing Permit (X) Renewal ( ) New Permit ( )

Permit Type: National Pollutant Discharge Elimination System (NPDES) - 40 CFR 122

Permitting Agency: U.S. Environmental Protection Agency, Region 10

Permit Number: WA-002591-7

Permitted Unit: 300 Area Treated Effluent Disposal Facility, Project L-045H

Issuance Date: October 31, 1994

Expiration Date: November 1, 1999

Need for Headquarters' Action

(for permit renewals or new permits)
Yes ( ) No (X)

If yes, HQ Program Element

Brief Summary of Relevant Information (major permit conditions, status of compliance or unusual problems):

The NPDES governs discharges to the Columbia River. The major permit conditions include discharge points, effluent limitations, and monitoring requirements.

The NPDES permit allows treatment and disposal of the process effluent to the Columbia River from industrial and research operations in the 300 Area. The 300 Area Treated Effluent Disposal Facility commenced discharge on December 30, 1994, meeting Tri-Party Agreement Milestone M-17-09. A letter was submitted to the EPA on August 1, 1996, identifying areas in the permit that need to be discussed for possible modification.

Note: The NPDES permit was reopened under the reopener clause on NPDES permit \#WA-002591-7. The permit was submitted to DOE-RL during July 1997 for subsequent transmittal to the EPA.

Compiled by: Waste Management Federal Services of Hanford, Inc.

Date: July 31, 1997

for Fluor Daniel Hanford, Inc. 
DOE Operations Office: Richland

DOE Facility: Hanford Site

Existing Permit ( ) Renewal ( ) New Permit (X)

Permit Type: Termination of Coverage Storm Water General Permit, No.: WA-R-10-00F, from Construction Activities, National Pollutant Discharge Elimination System (NPDES) - 40 CFR 122

Permitting Agency: U.S. Environmental Protection Agency Region 10

Permit Number: WA-R-10-000F

Permitted Unit: 300 Area Treated Effluent Disposal Facility, Project L-045H

Issuance Date: N/A

Expiration Date: N/A

Need for Headquarters' Action

(for permit renewals or new permits)
Yes ( ) No (X)

If yes, identify appropriate HQ

Program Element

Brief Summary of Relevant Information (major permit conditions, status of compliance or unusual problems):

The NPDES governs discharges to the Columbia River. The major permit conditions include discharge points, effluent limitations, and monitoring requirements.

A Notice of Termination of coverage was submitted to the EPA under this general permit on January 9, 1995, for the 300 Area Treated Effluent Disposal Facility outfall construction project, that was assigned permit number WA-R-10-A09F. There has not been any activity on this permit during the period covered by this Status Report.

Compiled by: Waste Management Federal Services of Hanford, Inc.

Date: July 31,1997 for Fluor Daniel Hanford, Inc. 
DOE Operations Office: Richland

DOE Facility: Hanford Site

Existing Permit (X) Renewal ( ) New Permit ( )

Permit Type: Clean Water Act, Section $404-33$ CFR 330

Permitting Agency: U.S. Army Corps of Engineers

Permit Number: 95-1-00441

Permitted Unit: $181 \mathrm{~B} / \mathrm{C}$ and D Fish Screen Replacement

Issuance Date: May 24, 1995

Expiration Date: May 24, 1998

Need for Headquarters' Action

Yes ( ) No (X)

(for permit renewals or new permits)

If yes, identify appropriate HQ

Program Element

Brief Summary of Relevant Information (major permit conditions, status of compliance or unusual problems):

This permit allows for dredging operations in the waters of the United States.

The $181 \mathrm{~B} / \mathrm{C}$ potable water intake requires dredging in front of the intake structure in the Columbia River to install a new passive fish screen. The application was submitted to the U.S. Army Corps of Engineers on March 10, 1995, with the dredging scheduled for August 1995. A certification of compliance was submitted to the U.S. Army Corps of Engineers on August 2, 1996.

Compiled by: Waste Management Federal Services of Hanford, Inc.

Date: July 31, 1997 for Fluor Daniel Hanford, Inc 
DOE Operations Office: Richland

DOE Facility: Hanford Site

Existing Permit ( ) Renewal ( ) $\quad$ New Permit (X)

Permit Type: Industrial Pretreatment Permit - 40 CFR 403 and city of Richland Ordinance 7-96

Permitting Agency: City of Richland, Water and Waste Utilities

Permit Number: CR-IU005

Permitted Unit: Environmental Molecular Science Laboratory

Issuance Date: October 1, 1996

Expiration Date: October 1, 2001

Need for Headquarters' Action

(for permit renewals or new permits)

Yes ( ) No (X)

If yes, HQ Program Element

Brief Summary of Relevant Information (major permit conditions, status of compliance or unusual problems):

The city of Richland has issued an Industrial Waste Water Discharge Pretreatment Permit to the Environmental Molecular Science Laboratory (EMSL) for waste water discharges to the city sewer system. The EMSL discharges laboratory-generated waste water to four 16,900-liter waste water retention tanks. Waste water is characterized from these tanks on a batch basis and is discharged on meeting the outfall discharge monitoring requirements.

Compiled by: Pacific Northwest National Laboratory

Date: July 31, 1997

Environmental Protection 
DOE Operations Office: Richland

DOE Facility: Hanford Site

Existing Permit ( $\mathrm{X}$ ) Renewal ( ) N New Permit ( )

Permit Type: Storm Water General Permit, No.: WA-R-000-00F, National Pollutant Discharge Elimination System (NPDES) - 40 CFR 122

Permitting Agency: U.S. Environmental Protection Agency, Region 10

Permit Number: WA-R-00A17F

Permitted Unit: Hanford Site (Storm Water General Permit)

Issuance Date: April 1994

Expiration Date: September 9, 1997

Need for Headquarters' Action

(for permit renewals or new permits)
Yes ( ) No ( $X)$

If yes, HQ Program Element

Brief Summary of Relevant Information (major permit conditions, status of compliance or unusual problems):

The Storm Water General Permit governs storm water discharges to the Columbia River. This permit requires a review and update to the Hanford Site Storm Water Pollution Prevention Plan, compiled annually by October 1, certified by DOE-RL, and maintained on file. This annual report, based on a storm water outfall survey, is scheduled to be completed October 1, 1997. A new Notice of Intent must be submitted (postmarked) to the EPA by September 7. 1997, for renewal of the existing permit.

Compiled by: Waste Management Federal Services of Hanford, Inc.

Date: July 31, 1997 for Fluor Daniel Hanford, Inc. 


\section{NATIONAL PARK SERVICE REVIEW PERMITTING}


This page intentionally left blank. 
DOE Operations Office: Richland

DOE Facility: Hanford Site

Existing Permit (X)

Renewal ( ) New Permit ( )

Permit Type: U.S. Park Service Review - Public Law 100-605

Permitting Agency: U.S. Park Service

Permit Number: N/A

Permitted Unit: 181 B/C and D Fish Screen Replacement

Issuance Date: April 11, 1995

Expiration Date: N/A

Need for Headquarters' Action Yes ( ) No (X)

(for permit renewals or new permits)

If yes, HQ Program Element

Brief Summary of Relevant Information (major permit conditions, status of compliance or unusual problems):

The Hanford Reach of the Columbia River remains under study for Wild and Scenic River designation by the National Park Service. Projects affecting such a designation are required to be reviewed and approved by the National Park Service.

The $181 \mathrm{~B} / \mathrm{C}$ and D Fish Screen Replacement project's review was approved in April 1995 and the 181 B/C and D Fish Screen Replacement was completed on May 24, 1996, and April 22, 1996, respectively. Those in operation are not subject to any major permit conditions and are operating in compliance and without any unusual problems.

The 181-B location continues to operate without significant problems.

The $181 \mathrm{C}$ location has been blocked as it is not needed.

The $181 \mathrm{D}$ location (serving as a backup to the 181-B location) has been replaced, and is operated only periodically.

The 181-DR screen is blocked off as it is no longer needed or used.

Compiled by: Waste Management Federal Services of Hanford, Inc.

Date: July 31, 1997

for Fluor Daniel Hanford, Inc. 
DOE/RL-96-63, Rev. 1

This page intentionally left blank. 
DOE/RL-96-63, Rev. 1 $10 / 97$

AQUATIC LANDS LEASE PERMITTING 
This page intentionally left blank. 
DOE Operations Office: Richland

DOE Facility: Hanford Site

Existing Permit (X) Renewal ( ) New Permit ( )

Permit Type: Application to Lease Aquatic Lands - WAC 173-201

Permitting Agency: State of Washington Department of Natural Resources

Permit Number: 20-013357

Permitted Unit: 300 Area Treated Effluent Disposal Facility, Project L-045H

Issuance Date: October 16, 1994

Expiration Date: October 15, 2024 (with 2 additional 10-year option periods)

Need for Headquarters' Action

(for permit renewals or new permits)
Yes ( ) No (X)

If yes, HQ Program Element

Brief Summary of Relevant Information (major permit conditions, status of compliance or unusual problems):

The 300 Area Treated Effluent Disposal Facility (Project L-045H) is designed to treat and dispose of the process effluent to the Columbia River from industrial and research operations in the 300 Area. An Aquatic Lands Lease allows placement of an outfall for discharge of the treated effluent on the bottom of the Columbia River. The Aquatic Lands Lease contains monitoring and notification requirements.

During the period covered by this Status Report, compliance has been maintained with the lease.

Compiled by: Waste Management Federal Services of Hanford, Inc. Date: July 31, 1997 for Fluor Daniel Hanford, Inc. 
This page intentionally left blank. 
DOE/RL-96-63, Rev. 1

\section{HYDRAULIC PROJECT APPROVAL PERMITTING}


DOE/RL-96-63, Rev. 1

10/97

This page intentionally left blank. 
DOE Operations Office: Richland.

DOE Facility: Hanford Site

Existing Permit ( ) $\quad$ Renewal ( ) New Permit (X)

Permit Type: Hydraulic Project Approval Application - WAC 220-110

Permitting Agency: State of Washington Department of Fish and Wildlife

Permit Number: Original: 00-A3722-02; Modified: 00-A3722-03

Permitted Unit: $181 \mathrm{~B} / \mathrm{C}$ and D Fish Screen Replacement

Issuance Date: Original: June 8, 1995; Modified: April 29, 1996

Expiration Date: Original: July 31, 1996; Modified: November 1, 1996

Need for Headquarters' Action

(for permit renewals or new permits)
Yes ( ) No (X)

If yes, HQ Program Element

Brief Summary of Relevant Information (major permit conditions, status of compliance or unusual problems):

The Hydraulic Project Approval covers construction work within the high water mark on all Washington State streams. Major project approval requirements prevent excess siltation of the stream and replacement of the riverine vegetation.

A Hydraulic Project Approval Application was submitted March 20,1995, to allow dredging and screening in front of the $181 \mathrm{~B} / \mathrm{C}$ and $\mathrm{D}$ water intake structures. A request to modify the project to include vacuuming of sediment from the interior of the $181-\mathrm{K}$ East river pumping station forebay was submitted. The Department of Fish and Wildlife approved the project on April 29, 1996.

The $181 \mathrm{~B} / \mathrm{C}$ and D Fish Screen Replacement project approval includes the vacuuming of sediment. The 181 B/C and D Fish Screen Replacement was completed on May 24, 1996, and April 22, 1996, respectively. The vacuuming of the sediment at the $181-\mathrm{K}$ East forebay was completed on May 30 , 1996.

The 181-B location continues to operate without significant problems. The $181 \mathrm{C}$ location has been blocked as it is not needed. The $181 \mathrm{D}$ location (serving as a backup to the 181-B location) has been replaced and is operated periodically. The 181-DR screen is blocked off as it is no longer needed or used. Those in operation are not subject to any major permit conditions and are operating in compliance and without any unusual problems.

Compiled by: Waste Management Federal Services of Hanford, Inc.

Date: July 31, 1997 for Fluor Daniel Hanford, Inc. 
DOE Operations Office: Richland

DOE Facility: Hanford Site

Existing Permit (.) Renewal ( ) New Permit (X)

Permit Type: Hydraulic Project Approval Application - WAC 220-110

Permitting Agency: State of Washington Department of Fish and Wildlife

Permit Number: 00-B8412-01

Permitted Unit: 181-K East Fish Screen Replacement

Issuance Date: April 29, 1996

Expiration Date: January 31, 1997

Need for Headquarters' Action

(for permit renewals or new permits)

Yes ( ) No (X)

If yes, HQ Program Element

Brief Summary of Relevant Information (major permit conditions, status of compliance or unusual problems):

The Hydraulic Project Approval covers construction work within the high water mark on all Washington State streams. Major project approval requirements prevent excess siltation of the stream and replacement of the riverine vegetation.

A Hydraulic Project Approval Application was submitted on April 19, 1996, to allow vacuum dredging and screening in the forebay of the $18 \mathrm{l}-\mathrm{K}$ East water intake structure. This Hydraulic Project Approval allows the diversion of water without installation of fish guards until the fuel has been removed from the $\mathrm{K}$ Basins in the 100 Area

The vacuum dredging notice to proceed was given to Thompson Mechanical who subcontracted to American Diving on May 21, 1996. The vacuum dredging was completed on June 6, 1996 and approximately 60 cubic meters of silt was removed from the forebay of $181-\mathrm{KE}$. No additional work has been done by project W-405 at $181-\mathrm{KE}$ water intake structure.

Compiled by: Waste Management Federal Services of Hanford, Inc. for Fluor Daniel Hanford, Inc.

Date: July 31,1997 
DOE/RL-96-63, Rev. 1

WATER QUALITY STANDARDS MODIFICATION PERMITTING 
DOE/RL-96-63, Rev. 1

$10 / 97$

This page intentionally left blank. 
DOE Operations Office: Richland

DOE Facility: Hanford Site

Existing Permit (X) Renewal ( ) New Permit ( )

Permit Type: Water Quality Standards Modification Order — WAC 173-201A

Permitting Agency: Washington State Department of Ecology

Permit Number: DE-95NM-024

Permitted Unit: $181 \mathrm{~B} / \mathrm{C}$ and D Fish Screen Replacement

Issuance Date: June 6, 1995

Expiration Date: August 31, 1995

Need for Headquarters' Action

(for permit renewals or new permits)

Yes ( ) No (X)

If yes, HQ Program Element

Brief Summary of Relevant Information (major permit conditions, status of compliance or unusual problems):

The Water Quality Standards Modification Request provides for the relaxation of water quality standards on a short-term basis to allow construction in Washington State streams. Appropriate pollution control measures are taken to prevent pollution of the stream.

A. Water Quality Standards Modification Request was submitted March 31, 1995, to allow dredging in the Columbia River in August 1995. The Order allowed the water quality criteria to be modified for a limited period between August 1, 1995, and August 31, 1995. The dredging was completed in August 1995. The 181 B/C and D Fish Screen Replacement project was completed on May 24, 1996, and April 22, 1996, respectively.

The 181-B location continues to operate without significant problems.

The $18 \mathrm{I} \mathrm{C}$ location has been blocked as it is not needed.

The $181 \mathrm{D}$ location (serving as a backup to the $181-\mathrm{B}$ location) has been replaced and is operated only periodically.

The 181-DR screen is blocked off as it is no longer needed or used.

Compiled by: Waste Management Federal Services of Hanford, Inc.

Date: July 31, 1997

for Fluor Daniel Hanford, Inc. 
DOE Operations Office: Richland

DOE Facility: Hanford Site

Existing Permit ( ) Renewal ( ) New Permit (X)

Permit Type: Water Quality Standards Modification Order - WAC 173-201A

Permitting Agency: Washington State Department of Ecology

Permit Number: DE-96-NM-034

Permitted Unit: 181-K Fish Screen Replacement

Issuance Date: May 1, 1996

Expiration Date: September 1, 1996

Need for Headquarters' Action

Yes ( ) No ( $\mathrm{X}$ )

(for permit renewals or new permits)

If yes, HQ Program Element

Brief Summary of Relevant Information (major permit conditions, status of compliance or unusual problems):

A Water Quality Standards Modification Order provides for the relaxation of water quality standards on a short-term basis to allow construction within Washington State streams. Appropriate pollution control measures are taken to prevent pollution of the stream.

A Water Quality Standards Modification Request was submitted to Ecology on April 19, 1996, to allow vacuum dredging in the forebay of the $181-\mathrm{K}$ East water intake structure. The Order allowed the water quality criteria to be modified for a 7-day period between May 1 and September 1, 1996. The vacuum dredging notice to proceed was given to Thompson Mechanical who subcontracted to American Diving on May 21, 1996. The vacuum dredging was completed on June 6, 1996, and approximately 60 meters of silt was removed from the forebay of $181-\mathrm{KE}$ water intake structure. No additional work has been done by project W-405 at $181-\mathrm{KE}$.

Compiled by: Waste Management Federal Services of Hanford, Inc.

Date: July 31, 1997

for Fluor Daniel Hanford, Inc. 
DOE/RL-96-63, Rev. 1

STATE WASTE DISCHARGE PERMITTING 
This page intentionally left blank. 
DOE Operations Office: Richland

DOE Facility: Hanford Site

Existing Permit ( )

Renewal ( )

New Permit (X)

Permit Type: State Waste Discharge Permit - WAC 173-216

Permitting Agency: Washington State Department of Ecology

Permit Number: ST 4507

Permitted Unit: $100-\mathrm{N}$ Sewage Lagoon

Issuance Date: May 12, 1997

Expiration Date: May 12, 2002

Need for Headquarters' Action

(for permit renewals or new permits)

Yes ( ) No (X)

If yes, HQ Program Element

Brief Summary of Relevant Information (major permit conditions, status of compliance or unusual problems):

Ecology Consent Order DE 91NM-177 lists regulatory milestones for liquid effluent streams on the Hanford Site to comply with the permitting requirements of WAC 173-216 (State Waste Discharge Program) or WAC 173-218 (Washington Underground Injection Control Program) where applicable. As a result, a WAC 173-216 State Waste Discharge Permit application was submitted for the 100-N Sewage Lagoon. The 100-N Sewage Lagoon receives sewage from facilities in the 100-N Area and from septic systems and holding tanks located across the Hanford Site. A Consent Order DE $91 N M-177$ milestone was satisfied with the submittal of the permit application to Ecology in June 1994. The final permit was issued.May 12, 1997.

Compiled by: Waste Management Federal Services of Hanford, Inc.

Date: July 31, 1997

for Fluor Daniel Hanford, Inc. 
DOE Operations Office: Richland

DOE Facility: Hanford Site

Existing Permit ( ) Renewal ( ) New Permit (X)

Permit Type: State Waste Discharge Permit - WAC 173-216

Permitting Agency: Washington State Department of Ecology

Permit Number: ST 4503

Permitted Unit: 183-N Backwash Discharge Pond

Issuance Date: May 12, 1997

Expiration Date: May 12, 2002

Need for Headquarters' Action

(for permit renewals or new permits)
Yes ( ) No (X)

If yes, HQ Program Element

Brief Summary of Relevant Information (major permit conditions, status of compliance or unusual problems):

Ecology Consent Order DE 91NM-177 lists regulatory milestones for liquid effluent streams at the Hanford Site to comply with the permitting requirements of WAC 173-216 (State Waste Discharge Program) or WAC 173-218 (Washington Underground Injection Control Program) where applicable. As a result, a WAC 173-216 State Waste Discharge Permit application (DOE/RL-94-23, Rev. 0) was submitted for the 183-N Filter Backwash Stream. The 183-N Filter Backwash Stream consists of waste water produced by backwashing the multimedia filter basins at the 183-N Water Treatment Facility. A Consent Order DE $91 \mathrm{NM}-177$ milestone was satisfied with the submittal of the permit application to Ecology in June 1994. Ecology issued a final permit on May 12, 1997.

Compiled by: Bechtel Hanford, Inc:

Date: July 31, 1997

Regulatory Support 
DOE Operations Office: Richland

DOE Facility: Hanford Site

Existing Permit ( $\mathrm{X}$ ) Renewal ( ) New Permit ( )

Permit Type: State Waste Discharge Permit - WAC 173-216

Permitting Agency: Washington State Department of Ecology

Permit Number: ST 4500

Permitted Unit: 200 Area Effluent Treatment Facility

Issuance Date: June 26, 1995

Expiration Date: June 30, 2000

Need for Headquarters' Action

(for permit renewals or new permits)

Yes ( ) No (X)

If yes, HQ Program Element

Brief Summary of Relevant Information (major permit conditions, status of compliance or unusual problems):

The State Waste Discharge Permit for the 200 Area Effluent Treatment Facility governs discharges of treated waste water to the State Approved Land Disposal Site. The permit conditions include effluent limitations and monitoring requirements. Compliance has been maintained with the permit conditions except for elevated sulfate concentration in a groundwater monitoring well. The elevated sulfate is not the result of the 200 Area Effluent Treatment Facility operations, but is attributed to existing sulfate in the soil near the State Approved Land Disposal Site.

Compiled by: Waste Management Federal Services of Hanford, Inc. for Fluor Daniel Hanford, Inc.

Date: July 31,1997 
DOE Operations Office: Richland

DOE Facility: Hanford Site
Existing Permit ( $\mathrm{X}$ )
Renewal ( )
New Permit ( )

Permit Type: State Waste Discharge Permit - WAC 173-216

Permitting Agency: Washington State Department of Ecology

Permit Number: ST 4502

Permitted Unit: 200 Area Treated Effluent Disposal Facility, Project W-049H

Issuance Date: April 18, 1995

Expiration Date: April 18, 2000

Need for Headquarters' Action

(for permit renewals or new permits)

\section{Yes ( ) No (X)}

If yes, HQ Program Element

Brief Summary of Relevant Information (major permit conditions, status of compliance or unusual problems):

State Waste Discharge Permit ST 4502 provides the terms and conditions that regulate the discharge of treated waste water from the 200 Area Treated Effluent Disposal Facility to the soil. Compliance with the permit conditions has been maintained except for several iron exceedances: Additional waste streams were added to the 200 Area Treated Effluent Disposal Facility in 1997. These new waste streams are the remaining streams associated with the C-lobe of B Pond. Permitting efforts associated with these new waste streams have been completed and approved by Ecology.

Compiled by: Waste Management Federal Services of Hanford, Inc.

Date: July 31, 1997 for Fluor Daniel Hanford, Inc. 
DOE Operations Office: Richland

DOE Facility: Hanford Site

Existing Permit ( )

Renewal ( )

New Permit ( X)

Permit Type: State Waste Discharge Permit - WAC 173-216

Permitting Agency: Washington State Department of Ecology

Permit Number: ST 4501

Permitted Unit: 400 Area Secondary Cooling Water

Issuance Date: July 31, 1997

Expiration Date: July 31, 2001

Need for Headquarters' Action

(for permit renewals or new permits)

Yes ( ) No (X)

If yes, HQ Program Element

Brief Summary of Relevant Information (major permit conditions, status of compliance or unusual problems):

Ecology Consent Order DE $91 \mathrm{NM}-177$ lists regulatory milestones for liquid effluent streams at the Hanford Site to comply with the permitting requirements of WAC 173-216 (State Waste Discharge Program) or WAC 173-218 (Washington Underground Injection Control Program) where applicable. As a result, a WAC 173-216 State Waste Discharge Permit application was submitted for the 400 Area Secondary Cooling Water stream. The 400 Area Secondary Cooling Water stream includes contributing streams for the Fuel Material Examination Facility, Maintenance and Storage Facility, 481-A Pump House, and Fast Flux Test Facility. The effluent is discharged to the 4608 Percolation Pond. A Consent Order DE $91 \mathrm{NM}-177$ milestone was satisfied with the submittal of the permit application to Ecology in December 1992. The Permit was issued in July 1996. Additional waste water characterization information was submitted to Ecology for temporary discharges to the 400 Area Ponds in late 1996. Ecology will determine if the permit needs to be modified to allow the discharges.

Compiled by: Waste Management Federal Services of Hanford, Inc.

Date: July 31,1997

for Fluor Daniel Hanford, Inc. 
DOE Operations Office: Richland

DOE Facility: Hanford Site

Existing Permit ( ) Renewal ( ) New Permit (X)

Permit Type: State Waste Discharge Permit - WAC 173-216

Permitting Agency: Washington State Department of Ecology

Permit Number:

Permitted Unit: Cooling Water and Condensate Discharges

Issuance Date: TBD

Expiration Date: TBD

Need for Headquarters' Action

(for permit renewals or new permits)

Yes ( ) No (X)

If yes, HQ Program Element

Brief Summary of Relevant Information (major permit conditions, status of compliance or unusual problems):

Ecology Consent Order DE 91NM-177 lists regulatory milestones for liquid effluent streams on the Hanford Site to comply with the permitting requirements of WAC 173-216 (State Waste Discharge Program) or WAC 173-218 (Washington Underground Injection Control Program) where applicable. The miscellaneous streams second categorical permit application for cooling water and condensate discharges was submitted to Ecology during September 1996. Ecology is preparing the permit.

Compiled by: Waste Management Federal Services of Hanford, Inc.

Date: July 31, 1997 for Fluor Daniel Hanford, Inc. 
DOE Operations Office: Richland

DOE Facility: Hanford Site

Existing Permit ( ) Renewal ( ) New Permit (X)

Permit Type: Categorical State Waste Discharge Permit - WAC 173-216

Permitting Agency: Washington State Department of Ecology

Permit Number: ST 4508

Permitted Unit: Hydrotesting, Construction, and Maintenance Discharges

Issuance Date: $\mathrm{TBD}$

Expiration Date: TBD

Need for Headquarters' Action

(for permit renewals or new permits)
Yes ( ) No (X)

If yes, HQ Program Element

Brief Summary of Relevant Information (major permit conditions, status of compliance or unusual problems):

State Waste Discharge Permit ST 4508 was issued by Ecology on May 30, 1997, and regulates hydrotesting, maintenance, and construction discharges on the Hanford Site. The permit identifies specific discharge requirements for flow rates and flow volume. The permit also requires submittal of a Pollution Prevention Plan to Ecology by November 30, 1997.

Compiled by: Waste Management Federal Services of Hanford, Inc.

Date: July 31, 1997 for Fluor Daniel Hanford, Inc. 
DOE Operations Office: Richland

DOE Facility: Hanford Site

Existing Permit ( ) Renewal ( ) New Permit (X)

Permit Type: Underground Injection Control Program - WAC 173-218

Permitting Agency: Washington State Department of Ecology

Permit Number: TBD

Permitted Unit: Class V Underground Injection Wells

Issuance Date: TBD

Expiration Date: TBD

Need for Headquarters' Action

(for permit renewals or new permits)
Yes ( ) No (X)

If yes, HQ Program Element

Brief Summary of Relevant Information (major permit conditions, status of compliance or unusual problems):

Information for registration of all Class $\mathrm{V}$ injection wells that inject industrial, municipal, or commercial waste fluids into or above an underground source of drinking water was submitted to Ecology on August 7, 1995, in accordance with commitments identified in the Plan and Schedule for Disposition and Regulatory Compliance for Miscellaneous Streams documentation. This represents the last registration of this information. Future revisions to the registration will be contingent upon available funding sources.

Compiled by: Waste Management Federal Services of Hanford, Inc.

Date: July 31, 1997 for Fluor Daniel Hanford, Inc. 
DOE/RL-96-63, Rev. 1

\section{ONSITE SEWAGE SYSTEM PERMITTING}


This page intentionally left blank. 
DOE Operations Office: Richland

DOE Facility: Hanford Site

Existing Permit ( ) Renewal ( ) New Permit (X)

Permit Type: Onsite Sewage System — WAC 246-272

Permitting Agency: Washington State Department of Health - Spokane

Permit Number: HAN099

Permitted Unit: 100B Area Septic Holding Tank System

Issuance Date: August $1996^{\circ}$

Expiration Date: TBD

Need for Headquarters' Action

(for permit renewals or new permits)
Yes ( ) No (X)

If yes, HQ Program Element

Brief Summary of Relevant Information (major permit conditions, status of compliance or unusual problems):

Holding tank sewage systems are permitted once in accordance with WAC 246-272-12501. Through negotiations with the Department of Health, the DOE-RL is allowed to install holding tank sewage systems on a temporary basis. The 100B Area support facility septic holding tank is a permitted holding tank system with a design capacity of 757 liters per day.

Compiled by: Bechtel Hanford, Inc.

Date: July 31, 1997

Regulatory Support 
DOE Operations Office: Richland

DOE Facility: Hanford Site

Existing Permit ( ) Renewal ( ) New Permit (X)

Permit Type: Onsite Sewage System - WAC 246-272

Permitting Agency: Washington State Department of Health - Spokane

Permit Number: HAN099

Permitted Unit: $100 \mathrm{~B} / \mathrm{C}$ Area Septic Holding Tank System

Issuance Date: May 1996

Expiration Date: TBD

Need for Headquarters' Action

(for permit renewals or new permits)
Yes ( ) No (X)

If yes, HQ Program Element

Brief Summary of Relevant Information (major permit conditions, status of compliance or unusual problems):

Holding tank sewage systems are permitted once in accordance with WAC 246-272-12501. Through negotiations with the Department of Health. the DOE-RL is allowed to install holding tank sewage systems on a temporary basis. The $100 \mathrm{~B} / \mathrm{C}$ Area septic holding tank is a permitted holding tank system with a design capacity of 1,136 liters per day.

Compiled by: Bechtel Hanford, Inc.

Date: July 31,1997

Regulatory Support 
DOE Operations Office: Richland

DOE Facility: Hanford Site

Existing Permit ( ) Renewal ( ) New Permit (X)

Permit Type: Onsite Sewage System - WAC 246-272

Permitting Agency: Washington State Department of Health - Spokane

Permit Number: HAN099

Permitted Unit: 100D Area Septic Holding Tank System

Issuance Date: August 1996

Expiration Date: TBD

Need for Headquarters' Action

(for permit renewals or new permits)

Yes ( ) No (X)

If yes, HQ Program Element

Brief Summary of Relevant Information (major permit conditions, status of compliance or unusual problems):

Holding tank sewage systems are permitted once in accordance with WAC 246-272-12501. Through negotiations with the Department of Health, the DOE-RL is allowed to install holding tank sewage systems on a temporary basis. The D-Area septic holding tank is a permitted holding tank system with a design capacity of 568 liters per day.

Compilèd by: Bechtel Hanford, Inc.

Date: July 31, 1997

Regulatory Support 
DOE Operations Office: Richland

DOE Facility: Hanford Site

Existing Permit ( ) Renewal (X) New Permit ( )

Permit Type: Onsite Sewage System — WAC 246-272

Permitting Agency: Washington State Department of Health - Spokane

Permit Number: N/A

Permitted Unit: 183-KE Septic Holding Tank

Issuance Date: October 17, 1996

Expiration Date: September 30, 1997

Need for Headquarters' Action

(for permit renewals or new permits)

Yes ( ) No (X)

If yes, HQ Program Element

Brief Summary of Relevant Information (major permit conditions, status of compliance or unusual problems):

Large onsite septic systems, septic systems with a design flow of greater than 13,249 liters per day, are permitted annually in accordance with WAC 246-272-08001. The 183-KE Septic Tank (Project 183-KE serving mobile office MO-293 in the 100 Area) is a large permitted onsite septic system with a design capacity of 14,384 liters per day

Compiled by: Waste Management Federal Services of Hanford, Inc.

Date: July 31, 1997 for Fluor Daniel Hanford, Inc. 
DOE Operations Office: Richland

DOE Facility: Hanford Site

Existing Permit ( ) $\quad$ Renewal (X) $\quad \cdot \quad$ New Permit ( )

Permit Type: Onsite Sewage System - WAC 246-272

Permitting Agency: Washington State Department of Health - Spokane

Permit Number: N/A

Permitted Unit: $2750-E$ and Adjacent Facilities Septic System

Issuance Date: October 17, 1996

Expiration Date: September 30, 1997

Need for Headquarters' Action

Yes ( ) No (X)

(for permit renewals or new permits) If yes, HQ Program Element

Brief Summary of Relevant Information (major permit conditions, status of compliance or unusual problems):

Large onsite septic systems, septic systems with a design flow of greater than 13,249 liters per day, are permitted annually in accordance with WAC 246-272-08001. The 2750-E septic system is a large permitted onsite septic system with a design capacity of 55,000 liters per day.

Compiled by: Waste Management Federal Services of Hanford, Inc.

Date: July 31, 1997 for Fluor Daniel Hanford, Inc. 
DOE Operations Office: Richland

DOE Facility: Hanford Site

Existing Permit (X) Renewal ( ) . New Permit ( )

Permit Type: Onsite Sewage System - WAC 246-272

Permitting Agency: Washington State Department of Health - Spokane

Permit Number: N/A

Permitted Unit: 222-S Laboratory Complex, Septic System

Issuance Date: October 17, 1996

Expiration Date: September 30, 1997

Need for Headquarters' Action

(for permit renewals or new permits)

\section{Yes ( ) No ( $\mathrm{X}$ )}

If yes, HQ Program Element

Brief Summary of Relevant Information (major permit conditions, status of compliance or unusual problems):

Large onsite septic systems are permitted once in accordance with WAC 246-272-12501. Through negotiations with the Department of Health. DOE-RL is allowed to install large onsite septic systems on a temporary basis for up to 5 years. The 222-S Laboratory Complex septic system has a design capacity of 50,000 liters per day.

Compiled by: Waste Management Federal Services of Hanford, Inc.

Date: July 31, 1997 for Fluor Daniel Hanford, Inc. 
DOE Operations Office: Richland

DOE Facility: Hanford Site

Existing Permit ( )

Renewal (X)

New Permit ( )

Permit Type: Onsite Sewage System - WAC 246-272

Permitting Agency: Washington State Department of Health - Spokane

Permit Number: HAN014

Permitted Unit: 1607-K4 Septic Tank

Issuance Date: October 17, 1996

Expiration Date: September 30, 1997

Need for Headquarters' Action

(for permit renewals or new permits)
Yeș ( ) No (X)

If yes, HQ Program Element

Brief Summary of Relevant Information (major permit conditions, status of compliance or unusual problems):

Large onsite septic systems, with a design flow of greater than 13,249 liters (3,500 gallons) per day, are permitted annually in accordance with WAC 246-272-08001. The 1607-K4 septic tank (Project 1607-K4 serving mobile offices MO-401 and MO-402 in the 100-K Area) is a large permitted onsite septic system with a design capacity of 14.384 liters per day.

Compiled by: Waste Management Federal Services of Hanford, Inc.

Date: July 31, 1997 for Fluor Daniel Hanford, Inc. 
DOE Operations Office: Richland.

DOE Facility: Hanford Site

Existing Permit ( ) Renewal (X) New Permit ( )

Permit Type: Onsite Sewage System — WAC 246-272

Permitting Agency: Washington State Department of Health - Spokane

Permit Number: HAN017

Permitted Unit: 2607-EP Septic Tank

Issuance Date: October 17, 1996

Expiration Date: September 30, 1997

Need for Headquarters' Action

(for permit renewals or new permits)

Yes ( ) No (X)

If yes, HQ Program Element

Brief Summary of Relevant Information (major permit conditions, status of compliance or unusual problems):

Large onsite septic systems, with a design flow of greater than 13,249 liters per day, are permitted annually in accordance with WAC 246-272-08001. The 2607-EP septic tank (Project L-132 serving building 2721-EA and adjacent facilities) is a large permitted onsite septic system with a design capacity of 54,888 liters per day.

Compiled by: Waste Management Federal Services of Hanford, Inc.

Date: July 31, 1997 for Fluor Daniel Hanford, Inc. 
DOE Operations Office: Richland

DOE Facility: Hanford Site

Existing Permit ( ) Renewal (X) New Permit ( )

Permit Type: Onsite Sewage System - WAC 246-272

Permitting Agency: Washington State Department of Health - Spokane

Permit Number: HAN016.

Permitted Unit: 2607-EQ Septic Tank

Issuance Date: October 17, 1996

Expiration Date: September 30, 1997

Need for Headquarters' Action

(for permit renewals or new permits)
Yes ( ) No ( $\mathrm{X}$ )

If yes, HQ Program Element

Brief Summary of Relevant Information (major permit conditions, status of compliance or unusual problems):

Large onsite septic systems, with a design flow of greater than 13,249 liters per day, are permitted annually in accordance with WAC 246-272-08001. The 2607-EQ septic tank (Project L092 serving buildings 2751-E, 2752-E, and 2753-E in the 200 East Area) is a large permitted onsite septic system with a design capacity of 54,131 liters per day.

Compiled by: Waste Management Federal Services of Hanford, Inc.

Date: July 31, 1997 for Fluor Daniel Hanford, Inc. 
DOE Operations Office: Richland

DOE Facility: Hanford Site

Existing Permit (X) Renewal ( ) New Permit ( )

Permit Type: Onsite Sewage System — WAC 246-272

Permitting Agency: Washington State Department of Health — Spokane

Permit Number: N/A

Permitted Unit: 2607-E10 Septic Tank

Issuance Date: October 17, 1996.

Expiration Date: September 30, 1997

Need for Headquarters' Action

(for permit renewals or new permits)
Yes ( ) No (X)

If yes, HQ Program Element

Brief Summary of Relevant Information (major permit conditions, status of compliance or unusual problems):

Onsite septic systems, with a design flow of less than 13,249 liters per day, currently are permitted once in accordance with WAC 246-272-09001. The 2607-E10 septic tank (Project W-299, Grout Processing Support Facility) is a permitted onsite septic system with a design capacity of 4, 164 liters per day.

Compiled by: Waste Management Federal Services of Hanford, Inc.

Date: July 31, 1997 for Fluor Daniel Hanford, Inc. 
DOE Operations Office: Richland

DOE Facility: Hanford Site

Existing Permit ( ) Renewal (X) New Permit ( )

Permit Type: Onsite Sewage System - WAC 246-272

Permitting Agency: Washington State Department of Health - Spokane

Permit Number: HAN012

Permitted Unit: 2607-E12 Septic Tank

Issuance Date: October 17, 1996

Expiration Date: September 30, 1997

Need for Headquarters' Action

(for permit renewals or new permits)
Yes ( ) No (X)

If yes, HQ Program Element

Brief Summary of Relevant Information (major permit conditions, status of compliance or unusual problems):

Large onsite septic systems, with a design flow of greater than 13,249 liters per day, are permitted annually in accordance with WAC 246-272-08001. The 2607-E12 septic tank (Project W-172 serving buildings $272-\mathrm{AW}, 242-\mathrm{A}$, and adjacent trailer units in the 200 East Area) is a large permitted onsite septic system with a design capacity of 25,400 liters per day.

Compiled by: Waste Management Federal Services of Hanford, Inc. for Fluor Daniel Hànford, Inc.

Date: July 31, 1997 
DOE Operations Office: Richland

DOE Facility: Hanford Site

Existing Permit (X) Renewal ( ) New Permit ( )

Permit Type: Onsite Sewage System — WAC 246-272

Permitting Agency: Washington State Department of Health - Spokane

Permit Number: N/Ȧ

Permitted Unit: 2607-WA East Septic Tank

Issuance Date: October 17, 1996

Expiration Date: September 30, 1997

Need for Headquarters' Action

(for permit renewals or new permits)

Yes ( ). No (X)

If yes, HQ Program Element

Brief Summary of Relevant Information (major permit conditions, status of compliance or unusual problems):

Onsite septic systems, with a design flow of less than 13,249 liters per day, currently are permitted once in accordance with WAC 246-272-09001. The 2607-WA East septic tank is a permitted onsite septic system with a design capacity of 2,540 liters per day.

Compiled by: Waste Management Federal Services of Hanford, Inc.

Date: July 31, 1997 for Fluor Daniel Hanford, Inc. 
DOE Operations Office: Richland

DOE Facility: Hanford Site

Existing Permit ( ) Renewal (X) New Permit ( )

Permit Type: Onsite Sewage System - WAC 246-272

Permitting Agency: Washington State Department of Health - Spokane

Permit Number: HAN009

Permitted Unit: 2607-WI and 2607-W2 Septic Tanks

Issuance Date: October 17, 1996

Expiration Date: September 30, 1997

Need for Headquarters' Action

(for permit renewals or new permits)
Yes ( ) No (X)

If yes, HQ Program Element

Brief Summary of Relevant Information (major permit conditions, status of compliance or unusual problems):

Large onsite septic systems, with a design flow of greater than 13,249 liters per day, are permitted annually in accordance with WAC 246-272-08001. The 2607-W1 and 2607-W2 septic tanks are a large permitted onsite septic system with a design capacity of 54,900 liters per day.

Compiled by: Waste Management Federal Services of Hanford, Inc. for Fluor Daniel Hanford, Inc. 
DOE Operations Office: Richiand

DOE Facility: Hanford Site

Existing Permit ( ) Renewal ( ) New Permit (X)

Permit Type: Onsite Sewage System - WAC 246-272

Permitting Agency: Washington State Department of Health - Spokane

Permit Number: N/A

Permitted Unit: 2607-W11 and 2607-W12 Septic Tanks

Issuance Date: October 17, 1996

Expiration Date: September 30, 1997

Need for Headquarters' Action

(for permit renewals or new permits)
Yes ( ) No (X)

If yes, HQ Program Element

Brief Summary of Relevant Information (major permit conditions, status of compliance or unusual problems):

Onsite septic systems, with a design flow of less than 13,249 liters per day, currently are permitted once in accordance with WAC 246-272-09001. The 2607-W1I and 2607-W12 septic tanks are a permitted onsite septic system with a design capacity of 4,921 liters per day.

Compiled by: Waste Management Federal Services of Hanford, Inc.

Date: July 31, 1997 for Fluor Daniel Hanford, Inc. 
DOE Operations Office: Richland

DOE Facility: Hanford Site

Existing Permit ( ) Renewal ( ) New Permit (X)

Permit Type: Onsite Sewage System — WAC 246-272

Permitting Agency: Washington State Department of Health - Spokane

Permit Number: N/A

Permitted Unit: 2607-W14 Septic Tank

Issuance Date: October 17, 1996

Expiration Date: September 30, 1997

Need for Headquarters' Action

(for permit renewals or new permits)

Yes ( ) No (X)

If yes, HQ Program Element

Brief Summary of Relevant Information (major permit conditions, status of compliance or unusual problems):

Onsite septic systems, with a design flow of less than 13,249 liters per day, currently are permitted once in accordance with WAC 246-272-09001. The 2607-W.14 septic tank is a permitted onsite septic system with a design capacity of 9,577 liters per day.

Compiled by: Waste Management Federal Services of Hanford, Inc. for Fluor Daniel Hanford, Inc.

Date: July 31, 1997 
DOE Operations Office: Richland

DOE Facility: Hanford Site

Existing Permit ( ) Renewal ( ) New Permit (X)

Permit Type: Onsite Sewage System - WAC 246-272

Permitting Agency: Washington State Department of Health - Spokane

Permit Number: N/A

Permitted Unit: 2607-W15 Septic Tank

Issuance Date: October 17, 1996

Expiration Date: September 30, 1997

Need for Headquarters' Action

(for permit renewals or new permits)
Yes ( ) No (X)

If yes, HQ Program Element

Brief Summary of Relevant Information (major permit conditions, status of compliance or unusual problems):

Onsite septic systems, with a design flow of less than 13,249 liters per day, currently are permitted once in accordance with WAC 246-272-09001. The 2607-W15 septic tank is a large permitted onsite septic system with a design capacity of 10,220 liters per day.

Compiled by: Waste Management Federal Services of Hanford, Inc.

Date: July 31, 1997 for Fluor Daniel Hanford, Inc. 
DOE Operations Office: Richland

DOE Facility: Hanford Site

Existing Permit ( ) Renewal (X) N New Permit ( )

Permit Type: Onsite Sewage System - WAC 246-272

Permitting Agency: Washington State Department of Health — Spokane

Permit Number: HAN011

Permitted Unit: 6607-9 Septic Tank

Issuance Date: October 17, 1996

Expiration Date: September 30, 1997

Need for Headquarters' Action

(for permit renewals or new permits)

$$
\begin{aligned}
& \text { Yes ( ) No (X) } \\
& \text { If yes, HQ Program Element }
\end{aligned}
$$

Brief Summary of Relevant Information (major permit conditions, status of compliance or unusual problems):

Large onsite septic systems, with a design flow of greater than 13,249 liters per day, are permitted annually in accordance with WAC 246-272-08001. The 6607-9 septic tank is a large permitted onsite septic system with a design capacity of 25,362 liters per day

Compiled by: Waste Management Federal Services of Hanford, Inc.

Date: July 31, 1997 for Fluor Daniel Hanford, Inc. 
DOE Operations Office: Richland

DOE Facility: Hanford Site

Existing Permit ( ) Renewal (X) New Permit ( )

Permit Type: Onsite Sewage System — WAC 246-272

Permitting Agency: Washington State Department of Health — Spokane

Permit Number: HAN003

Permitted Unit: 6607-11 Septic Tank

Issuance Date: October 17, 1996

Expiration Date: September 30, 1997

Need for Headquarters' Action

(for permit renewals or new permits)
Yes ( ) No (X)

If yes, HQ Program Element

Brief Summary of Relevant Information (major permit conditions, status of compliance or unusual problems):

Large onsite septic systems, with a design flow of greater than 13,249 liters per day, are permitted annually in accordance with WAC $246-272-08001$. The 6607-11 septic tank is a large permitted onsite septic system with a design capacity of 44,668 liters per day.

Compiled by: Waste Management Federal Services of Hanford, Inc.

Date: July 31, 1997 for Fluor Daniel Hanford, Inc. 
DOE Operations Office: Richland

DOE Facility: Hanford Site

Existing Permit ( ) Renewal (X) New Permit ( )

Permit Type: Onsite Sewage System - WAC 246-272

Permitting Agency: Washington State Department of Health - Spokane

Permit Number: HAN005

Permitted Unit: $6607-16$ Septic Tank

Issuance Date: October 17, 1996

Expiration Date: September 30, 1997

Need for Headquarters' Action

(for permit renewals or new. permits)
Yes ( ) No $(X)$

If yes, HQ Program Element

Brief Summary of Relevant Information (major permit conditions, status of compliance or unusual problems):

Large onsite septic systems, with a design flow of greater than 13,249 liters per day, are permitted annually in accordance with WAC 246-272-08001. The 6607-16 septic tank is a large permitted onsite septic system with a design capacity of 18,927 liters per day.

Compiled by: Waste Management Federal Services of Hanford, Inc.

Date: July 31, 1997 for Fluor Daniel Hanford, Inc. 
DOE Operations Office: Richland

DOE Facility: Hanford Site

Existing Permit ( ) Renewal ( ) New Permit (X)

Permit Type: Onsite Sewage System - WAC 246-272

Permitting Agency: Washington State Department of Health - Spokane

Permit Number: N/A

Permitted Unit: 6607-17 Septic Tank

Issuance Date: October 17, 1996

Expiration Date: September 30, 1997

Need for Headquarters' Action

(for permit renewals or new permits)
Yes () No (X)

If yes, HQ Program Element

Brief Summary of Relevant Information (major permit conditions, status of compliance or unusual problems):

Onsite septic systems, with a design flow of less than 13,249 liters per day, currently are permitted once in accordance with WAC 246-272-09001. The 6607-17 septic tank is a permitted onsite septic system with a design capacity of 1,365 liters per day.

Compiled by: Waste Management Federal Services of Hanford, Inc.

Date: July 31, 1997 for Fluor Daniel Hanford, Inc. 
DOE Operations Office: Richland

DOE Facility: Hanford Site

Existing Permit ( ) Renewal (X) New Permit ( )

Permit Type: - Onsite Sewage System - WAC 246-272

Permitting Agency: Washington State Department of Health - Spokane

Permit Number: HAN099

Permitted Unit: Environmental Molecular Sciences Laboratory Temporary Septic Holding Tank

Issuance Date: October 17, 1996

Expiration Date: September 30, 1997

Need for Headquarters' Action

(for permit renewals or new permits)
Yes ( ) No (X)

If yes, HQ Program Element

Brief Summary of Relevant Information (major permit conditions, status of compliance or unusual problems):

Septic system holding tanks are required to obtain permits pursuant to WAC 246-272. The Environmental Molecular Sciences Laboratory (EMSL) temporary septic holding tank (Project D-384 servicing the construction trailers) maintains a temporary sanitary waste water holding tank. The septic holding tank will be used until the EMSL has completed construction activities. The holding tank will be removed upon completion of the construction activities.

Compiled by: Pacific Northwest National Laboratory

Date: July 31, 1997

Environmental Protection 
DOE Operations Office: Richland

DOE Facility: Hanford Site

Existing Permit (X) Renewal ( ) N New Permit ( )

Permit Type: Onsite Sewage System - WAC 246-272

Permitting Agency: Washington State Department of Health - Spokane

Permit Number: HAN099

Permitted Unit: Environmental Restoration Disposal Facility Construction Trailer Septic Holding Tank System

Issuance Date: October 1995

Expiration Date: TBD

Need for Headquarters' Action

(for permit renewals or new permits)
Yes ( ) No (X)

If yes, HQ.Program Element

Brief Summary of Relevant Information (major permit conditions, status of compliance or unusual problems):

Holding tank sewage systems are permitted once in accordance with WAC 246-272-12501. Through negotiations with the Department of Health, the DOE-RL is allowed to install holding tank sewage systems on a temporary basis. The Environmental Restoration Disposal Facility construction trailer septic holding tank system is a permitted holding tank system with a design capacity of 227 liters per day.

Compiled by: Bechtel Hanford, Inc.

Date: July 31, 1997

Regulatory Support 
DOE Operations Office: Richland

DOE Facility: Hanford Site

Existing Permit (X) Renewal ( ) New Permit ( )

Permit Type: Onsite Sewage System - WAC 246-272

Permitting Agency: Washington State Department of Health - Spokane

Permit Number: HAN099

Permitted Unit: Environmental Restoration Disposal Facility Septic Holding Tank

Issuance Date: September 1995

Expiration Date: TBD

Need for Headquarters' Action

(for permit renewals or new permits)
Yes ( ) No (X)

If yes, HQ Program Element

Brief Summary of Relevant Information (major permit conditions, status of compliance or unusual problems):

Holding tank sewage systems are permitted once in accordance with WAC 246-272-12501. Through negotiations with the Department of Health, the DOE-RL is allowed to install holding tank sewage systems on a temporary basis. The Environmental Restoration Disposal Facility septic holding tank is a permitted holding tank system with a design capacity of 2,841 liters per day.

Compiled by: Bechtel Hanford, Inc.

Date: July 31, 1997

Regulatory Support 
DOE Operations Office: Richland

DOE Facility: Hanford Site

Existing Permit (X) Renewal ( ) New Permit ( )

Permit Type: Onsite Sewage System - WAC 246-272

Permitting Agency: Washington State Department of Health - Spokane

Permit Number: HAN099

Permitted Unit: Environmental Restoration Diṣposal Facility Shop Facility Septic Holding Tank System

Issuance Date: July 1996

Expiration Date: TBD

Need for Headquarters' Action

(for permit renewals or new permits)

\section{Yes ( ) No (X)}

If yes, HQ Program Element

Brief Summary of Relevant Information (major permit conditions, status of compliance or unusual problems):

Holding tank sewage systems are permitted once in accordance with WAC 246-272-12501. Through negotiations with the Department of Health, the DOE-RL is allowed to install holding tank sewage systems on a temporary basis. The Environmental Restoration Disposal Facility shop facility septic holding tank is a permitted holding tank system with a design capacity of 795 liters per day.

Compiled by: Bechtel Hanford, Inc.

Date: July 31,1997

Regulatory Support 


\section{PETROLEUM UNDERGROUND STORAGE TANK PERMITTING}


This page intentionally left blank. 
DOE Operations Office: Richland

DOE Facility: Hanford Site

Existing Permit ( ) Renewal (X) New Permit ( )

Permit Type: Annual Permit for Active Petroleum Underground Storage Tanks - WAC 173-360

Permitting Agency: Washington State Department of Ecology

Permit Number: $181 \mathrm{~B}-66$

Permitted Unit: 100B Area, 181B-66 Tank

Issuance Date: October 17, 1996

Expiration Date: September 30, 1997

Need for Headquarters' Action

(for permit renewals or new permits)

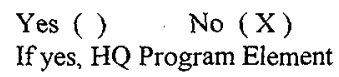

Brief Summary of Relevant Information (major permit conditions, status of compliance or unusual problems):

Annual permits and information updates are required each year for each active petroleum underground storage tank on the Hanford Site. The petroleum underground storage tanks store used oil, supply gasoline fuel for site vehicles, and supply diesel fuel for site vehicles and emergency generator systems. The 181B-66 tank contained diesel fuel. A tank permit was renewed with Master Business License 601310923 issued on June 30, 1997. This tank is temporarily closed under WAC 173-360.

Compiled by: Waste Management Federal Services of Hanford, Inc. for Fluor Daniel Hanford, Inc.

Date: July 31, 1997 
DOE Operations Office: Richland

DOE Facility: Hanford Site

Existing Permit ( ) Renewal (X) New Permit ( )

Permit Type: Annual Permit for Active Petroleum Underground Storage Tanks - WAC 173-360

Permitting Agency: Washington State Department of Ecology

Permit Number: 204-AR

Permitted Unit: 200 East Area, 204-AR Tank

Issuance Date: June 30, 1997

Expiration Date: June 30, 1998

Need for Headquarters' Action

(for permit renewals or new permits)

Yes ( ) No (X)

If yes, HQ Program Element

Brief Summary of Relevant Information (major permit conditions, status of compliance or unusual problems):

Annual permits and information updates are required each year for each active petroleum underground storage tank on the Hanford Site. The petroleum underground storage tanks store used oil, supply gasoline fuel for site vehicles, and supply diesel fuel for site vehicles and emergency generator systems. The 204-AR tank contains diesel fuel. The tank permit was renewed with Master Business License 601310923 issued on June 30, 1997.

Compiled by: Waste Management Federal Services of Hanford, Inc.

Date: July 31, 1997 for Fluor Daniel Hanford, Inc. 
DOE Operations Office: Richland

DOE Facility: Hanford Site

Existing Permit ( ) Renewal (X) New Permit ( )

Permit Type: Annual Permit for Active Petroleum Underground Storage Tanks - WAC 173-360

Permitting Agency: Washington State Department of Ecology

Permit Number: 241-A-701-1

Permitted Unit: 200 East Area, 241-A-701-1 Tank

Issuance Date: June 30, 1997

Expiration Date: June 30, 1998

Need for Headquarters' Action

Yes ( ) No (X)

(for permit renewals or new permits)

If yes, HQ Program Element

Brief Summary of Relevant Information (major permit conditions, status of compliance or unusual problems):

Annual permits and information updates are required each year for each active petroleum underground storage tank on the Hanford Site. The petroleum underground storage tanks store used oil, supply gasoline fuel for site vehicles, and supply diesel fuel for site vehicles and emergency generator systems. The 241-A-701-1 tank contains diesel fuel. The tank permit was renewed with Master Business License 601310923 issued on June 30, 1997.

Compiled by: Waste Management Federal Services of Hanford, Inc.

Date: July 31, 1997 for Fluor Daniel Hanford, Inc. 
DOE Operations Office: Richland

DOE Facility: Hanford Site

Existing Permit ( ) Renewal (X) New Permit ( )

Permit Type: Annual Permit for Active Petroleum Underground Storage Tanks - WAC 173-360

Permitting Agency: Washington State Department of Ecology

Permit Number: 241-A-701-2

Permitted Unit: 200 East Area, 241-A-701-2 Tank

Issuance Date: June 30, 1997

Expiration Date: June 30, 1998

Need for Headquarters' Action

(for permit renewals or new permits)

Yes ( ) No (X)

If yes, HQ Program Element

Brief Summary of Relevant Information (major permit conditions, status of compliance or unusual problems):

Annual permits and information updates are required each year for each active petroleum underground storage tank on the Hanford Site. The petroleum underground storage tanks store used oil, supply gasoline fuel for site vehicles, and supply diesel fuel for site vehicles and emergency generator systems. The 241-A-701-2 tank contains diesel fuel. The tank permit was renewed with Master Business License 601310923 issued on June 30, 1997.

Compiled by: Waste Management Federal Services of Hanford, Inc.

Date: July 31, 1997 for Fluor Daniel Hanford, Inc. 
DOE Operations Office: Richland

DOE Facility: Hanford Site

Existing Permit ( ) Renewal (X) New Permit ( )

Permit Type: Annual Permit for Active Petroleum Underground Storage Tanks - WAC 173-360

Permitting Agency: Washington State Department of Ecology

Permit Number: 242-A-1

Permitted Unit: 200 East Area, 242-A-1 Tank

Issuance Date: June 30, 1997

Expiration Date: June 30, 1998

Need for Headquarters' Action

(for permit renewals or new permits)

\section{Yes ( ) No (X)}

If yes, HQ Program Element

Brief Summary of Relevant Information (major permit conditions, status of compliance or unusual problems):

Annual permits and information updates are required each year for each active petroleum underground storage tank on the Hanford Site. The petroleum underground storage tanks store used oil, supply gasoline fuel for site vehicles, and supply diesel fuel for site vehicles and emergency generator systems. The 242-A-1 tank contains diesel fuel. The tank permit was renewed with Master Business License 601310923 issued on June 30, 1997.

Compiled by: Waste Management Federal Services of Hanford, Inc.

Date: July 31, 1997

for Fluor Daniel Hanford, Inc. 
DOE Operations Office: Richland

DOE Facility: Hanford Site

Existing Permit ( ) Renewal (X) New Permit ( )

Permit Type: Annual Permit for Active Petroleum Underground Storage Tanks - WAC 173-360

Permitting Agency: Washington State Department of Ecology

Permit Number: 244-AR

Permitted Unit: 200 East Area, 244-AR Tank

Issuance Date: June 30, 1997

Expiration Date: June 30, 1998

Need for Headquarters' Action

(for permit renewals or new permits)

Yes ( ) No ( $X)$

If yes, HQ Program Element

Brief Summary of Relevant Information (major permit conditions, status of compliance or unusual problems):

Annual permits and information updates are required each year for each active petroleum underground storage tank on the Hanford Site. The petroleum underground storage tanks store used oil, supply gasoline fuel for site vehicles, and supply diesel fuel for site vehicles and emergency generator systems. The 244-AR tank contains diesel fuel. The tank permit was renewed with Master Business License 601310923 issued on June 30, 1997

Compiled by: Waste Management Federal Services of Hanford, Inc.

Date: July 31, 1997 for Fluor Daniel Hanford, Inc. 
DOE Operations Office: Richland

DOE Facility: Hanford Site

Existing Permit ( ) . Renewal (X) New Permit ( )

Permit Type: Annual Permit for Active Petroleum Underground Storage Tanks - WAC 173-360

Permitting Agency: Washington State Department of Ecology

Permit Number: 2711E-66

Permitted Unit: 200 East Area, 2711-66 Tank

Issuance Date: June 30, 1997

Expiration Date: June 30, 1998

Need for Headquarters' Action (for permit renewals or new permits)

Yes ( ) No (X)

If yes, HQ Program Element

Brief Summary of Relevant Information (major permit conditions, status of compliance or unusual problems):

Annual permits and information updates are required each year for each active petroleum underground storage tank on the Hanford Site. The petroleum underground storage tanks store used oil, supply gasoline fuel for site vehicles, and supply diesel fuel for site vehicles and emergency generator systems. The 271 1-66 tank contains used oil. The tank permit was renewed with Master Business License 601310923 issued on June 30, 1997.

Compiled by: Waste Management Federal Services of Hanford, Inc. for Fluor Daniel Hanford, Inc.

Date: July 31,1997 
DOE Operations Office: Richland

DOE Facility: Hanford Site

Existing Permit ( ) Renewal (X) New Permit ( )

Permit Type: Annual Permit for Active Petroleum Underground Storage Tanks - WAC 173-360

Permitting Agency: Washington State Department of Ecology

Permit Number: 2711 E-66

Permitted Unit: 200 East Area, 2711-66A Tank

Issuance Date: June 30, 1997

Expiration Date: June 30, 1998

Need for Headquarters' Action

Yes ( ) No (X)

(for permit renewals or new permits)

If yes, HQ Program Element

Brief Summary of Relevant Information (major permit conditions, status of compliance or unusual problems):

Annual permits and information updates are required each year for each active petroleum underground storage tank on the Hanford Site. The petroleum underground storage tanks store used oil, supply gasoline fuel for site vehicles, and supply diesel fuel for site vehicles and emergency generator systems. The 2711-66A tank contains used oil. The tank permit was renewed with Master Business License 601310923 issued on June 30, 1997.

Compiled by: Waste Management Federal Services of Hanford, Inc.

Date: July 31, 1997 for Fluor Daniel Hanford, Inc. 
DOE Operations Office: Richland

DOE Facility: Hanford Site

Existing Permit ( ) Renewal (X) New Permit ( )

Permit Type: Annual Permit for Active Petroleum Underground Storage Tanks - WAC 173-360

Permitting Agency: Washington State Department of Ecology

Permit Number: 2721Z-1

Permitted Unit: 200 West Area, 2721Z-1 Tank

Issuance Date: June 30, 1997

Expiration Date: June 30, 1998

Need for Headquarters' Action Yes ( ) No (X)

(for permit renewals or new permits)

If yes, HQ Program Element

Brief Summary of Relevant Information (major permit conditions, status of compliance or unusual problems):

Annual permits and information updates are required each year for each active petroleum underground storage tank on the Hanford Site. The petroleum underground storage tanks store used oil, supply gasoline fuel for site vehicles, and supply diesel fuel for site vehicles and emergency generator systems. The 2721Z-1 tank contains diesel fuel. The tank permit was renewed with Master Business License 601310923 issued on June 30, 1997.

Compiled by: Waste Management Federal Services of Hanford, Inc.

Date: July 31, 1997 for Fluor Daniel Hanford, Inc. 
DOE Operations Office: Richland

DOE Facility: Hanford Site

Existing Permit ( )

Renewal (X)

New Permit ( )

Permit Type: Annual Permit for Active Petroleum Underground Storage Tanks - WAC 173-360

Permitting Agency: Washington State Department of Ecology

Permit Number: 2736ZA-1

Permitted Unit: 200 West Area, 2736ZA-1 Tank

Issuance Date: June 30, 1997

Expiration Date: June 30, 1998

Need for Headquarters' Action

(for permit renewals or new permits)

Yes. ( ) No (X)

If yes, HQ Program Element

Brief Summary of Relevant Information (major permit conditions, status of compliance or unusual problems):

Annual permits and information updates are required each year for each active petroleum underground storage tank on the Hanford Site. The petroleum underground storage tanks store used oil, supply gasoline fuel for site vehicles, and supply diesel fuel for site vehicles and emergency generator systems. The 2736ZA-l tank contains diesel fuel. The tank permit was renewed with Master Business License 601310923 issued on June 30, 1997.

Compiled by: Waste Management Federal Services of Hanford, Inc.

Date: July 31,1997 for Fluor Daniel Hanford, Inc. 
DOE Operations Office: Richland

DOE Facility: Hanford Site

Existing Permit ( ) Renewal (X) New Permit ( )

Permit Type: Annual Permit for Active Petroleum Underground Storage Tanks - WAC 173-360

Permitting Agency: Washington State Department of Ecology

Permit Number: $3621-\mathrm{C}$

Permitted Unit: 300 Area, 3621-C Tank

Issuance Date: June 30, 1997

Expiration Date: June 30, 1998

Need for Headquarters' Action

(for permit renewals or new permits)

Yes ( ) No (X)

If yes, HQ Program Element

Brief Summary of Relevant Information (major permit conditions, status of compliance or unusual problems):

Annual permits and information updates are required each year for each active petroleum underground storage tank on the Hanford Site. The petroleum underground storage tanks store used oil, supply gasoline fuel for site vehicles, and supply diesel fuel for site vehicles and emergency generator systems. The 3621-C tank contains diesel fuel. The tank permit was renewed with Master Business License 601310923 issued on June 30, 1997.

Compiled by: Waste Management Federal Services of Hanford, Inc.

Date: July 31, 1997 for Fluor Daniel Hanford, Inc. 
DOE Operations Office: Richland

DOE Facility: Hanford Site

Existing Permit ( ) Renewal ( ) New Permit (X)

Permit Type: Annual Permit for Active Petroleum Underground Storage Tanks - WAC 173-360

Permitting Agency: Washington State Department of Ecology

Permit Number: $3621-66$

Permitted Unit: 300 Area, 3621-66 Tank

Issuance Date: June 30, 1997

Expiration Date: June 30, 1998

Need for Headquarters' Action

(for permit renewals or new permits)
Yes ( ) No (X)

If yes, HQ Program Element

Brief Summary of Relevant Information (major permit conditions, status of compliance or unusual problems):

Annual permits and information updates are required each year for each active petroleum underground storage tank on the Hanford Site. The petroleum underground storage tanks store used oil, supply gasoline fuel for site vehicles, and supply diesel fuel for site vehicles and emergency generator systems. The 3621-66 tank contains diesel fuel. A new underground storage tank permit was submitted with Master Business License 601310923 issued on June 30, 1997.

Compiled by: Waste Management Federal Services of Hanford, Inc.

Date: July 31, 1997 for Fluor Daniel Hanford, Inc. 
DOE Operations Office: Richland

DOE Facility: Hanford Site

Existing Permit ( ) Renewal (X) New Permit ( )

Permit Type: Annual Permit for Active Petroleum Underground Storage Tanks - WAC 173-360

Permitting Agency: Washington State Department of Ecology

Permit Number: 400-FFTF-T303

Permitted Unit: 400 Area, 400-FFTF-T303 Tank

Issuance Date: June 30, 1997

Expiration Date: June 30, 1998

Need for Headquarters' Action

(for permit renewals or new permits)
Yes ( ) No (X)

If yes, HQ Program Element

Brief Summary of Relevant Information (major permit conditions, status of compliance or unusual problems):

Annual permits and information updates are required each year for each active petroleum underground storage tank on the Hanford Site. The petroleum underground storage tanks store used oil, supply gasoline fuel for site vehicles, and supply diesel fuel for site vehicles and emergency generator systems. The 400-FFTF-T303 tank contains diesel fuel. The tank permit was renewed with Master Business License 601310923 issued on June 30, 1997.

Compiled by: Waste Management Federal Services of Hanford, Inc.

Date; July 31, 1997 for Fluor Daniel Hanford, Inc. 
DOE Operations Office: Richland

DOE Facility: Hanford Site

Existing Permit ( ) Renewal ( ) New Permit (X)

Permit Type: Annual Permit for Active Petroleum Underground Storage Tanks - WAC 173-360

Permitting Agency: Washington State Department of Ecology

Permit Number: 6291-66

Permitted Unit: 600 Area, 6291-66 Tank

Issuance Date: June 30, 1997

Expiration Date: June 30, 1998

Need for Headquarters' Action

(for permit renewals or new permits)
Yes ( ) No ( $\mathrm{X}$ )

If yes, HQ Program Element

Brief Summary of Relevant Information (major permit conditions, status of compliance or unusual problems):

Annual permits and information updates are required each year for each active petroleum underground storage tank on the Hanford Site. The petroleum underground storage tanks store used oil, supply gasoline fuel for site vehicles, and supply diesel fuel for site vehicles and emergency generator systems. The 6291-66 tank contains diesel fuel. A new underground storage tank permit was submitted with Master Business License 601310923 issued on June 30, 1997.

Compiled by: Waste Management Federal Services of Hanford, Inc.

Date: July 31, 1997 for Fluor Daniel Hanford, Inc. 
DOE Operations Office: Richland

DOE Facility: Hanford Site

Existing Permit ( ) Renewal ( ) New Permit (X)

Permit Type: Annual Permit for Active Petroleum Underground Storage Tanks - WAC 173-360

Permitting Agency: Washington State Department of Ecology

Permit Number: 6291-66A

Permitted Unit: 600 Area, 6291-66A Tank

Issuance Date: June 30, 1997

Expiration Date: June 30, 1998

Need for Headquarters' Action

(for permit renewals or new permits)

Yes ( ) No (X)

If yes, HQ Program Element

Brief Summary of Relevant Information (major permit conditions, status of compliance or unusual problems):

Annual permits and information updates are required each year for each active petroleum underground storage tank on the Hanford Site. The petroleum underground storage tanks store used oil, supply gasoline fuel for site vehicles, and supply diesel fuel for site vehicles and emergency generator systems. The 6291-66A tank contains diesel fuel. A new underground storage tank permit was submitted with a Master Business License 601310923 issued on June 30, 1997.

Compiled by: Waste Management Federal Services of Hanford, Inc.

Date: July 31, 1997 for Fluor Daniel Hanford, Inc. 
DOE Operations Office: Richland

DOE Facility: Hanford Site
Existing Permit ( )
Renewal ( )
New Permit $(X)$

Permit Type: Annual Permit for Active Petroleum Underground Storage Tanks - WAC 173-360

Permitting Agency: Washington State Department of Ecology

Permit Number: $1172-66$

Permitted Unit: 1100 Area, 1172-66 Tank

Issuance Date: June 30, 1997

Expiration Date: June 30, 1998

Need for Headquarters' Action

(for permit renewals or new permits)

Yes ( ) No (X)

If yes, HQ Program Element

Brief Summary of Relevant Information (major permit conditions, status of compliance or unusual problems):

Annual permits and information updates are required each year for each active petroleum underground storage tank on the Hanford Site. The petroleum underground storage tanks store used oil, supply gasoline fuel for site vehicles, and supply diesel fuel for site vehicles and emergency generator systems. The 1172-66 tank contains diesel fuel. A new underground storage tank permit was submitted with a Master Business License 601310923 issued on June 30, 1997.

Compiled by: Waste Management Federal Services of Hanford, Inc.

Date: July 31, 1997 for Fluor Daniel Hanford, Inc. 
DOE Operations Office: Richland

DOE Facility: Hanford Site

Existing Permit ( ) Renewal ( ) New Permit (X)

Permit Type: Annual Permit for Active Petroleum Underground Storage Tanks - WAC 173-360

Permitting Agency: Washington State Department of Ecology

Permit Number: $1172-66 \mathrm{~A}$

Permitted Unit: 1100 Area, 1172-66A Tank

Issuance Date: June 30, 1997

Expiration Date: June 30, 1998

Need for Headquarters' Action

(for permit renewals or new permits)

Yes ( ) No (X)

If yes, HQ Program Element

Brief Summary of Relevant Information (major permit conditions, status of compliance or unusual problems):

Annual permits and information updates are required each year for each active petroleum underground storage tank on the Hanford Site. The petroleum underground storage tanks store used oil, supply gasoline fuel for site vehicles, and supply diesel fuel for site vehicles and emergency generator systems. The 1172-66A tank contains diesel fuel. A new underground storage tank permit was submitted with a Master Business License 601310923 issued on June 30, 1997.

Compiled by: Waste Management Federal Services of Hanford, Inc.

Date: July 31, 1997 for Fluor Daniel Hanford, Inc. 
DOE/RL-96-63, Rev. 1

$10 / 97$

This page intentionally left blank. 


\section{REFERENCES}

DOE, 1997, Hanford Facility Dangerous Waste Permit Application, General Information Portion, DOE/RL-91-28, Rev. 3, U.S. Department of Energy, Richland Operations Office, Richland, Washington.

Ecology, EPA, and DOE, 1996, Hanford Federal Facility Agreement and Consent Order, Washington State Department of Ecology, U.S. Environmental Protection Agency, and U.S. Department of Energy, Olympia, Washington, amended periodically.

Ecology and U.S. DOE, 1991, Consent Order No. DE9IN-177, Washington Department of Ecology, and U.S. Department of Energy, Olympia, Washington. 
DOE/RL-96-63, Rev. 1

$10 / 97$

This page intentionally left blank. 


\section{Offsite}

G. P. Davis

Washington State Department of Ecology

M. N. Jaraysi (2)

Washington State Department of Ecology

S. J. Skurla

Washington State Department of Ecology

J. R. Wilkinson

Department of Natural Resources

Confederated Tribes of the Umatilla Indian Reservation

P.O. Box 638

Pendleton, OR 97801

R. Jim, Manager

Restoration /Waste management

Confederated Tribes and Bands of the Yakama Nation P.O. Box 151

Toppenish, WA 98948

D. Powaukee

Nez Perce Tribe

P.O. Box 305

Lapwai, ID 80540

A. W. Conklin, Head

Air Emissions and Defense

Waste Section

Division of Radiation Protection

Washington State Department of Health

P.O. Box 47827

Olympia, Washington 98504-7827

D. Sherwood

Environmental Protection Agency 


\section{Onsite}

U.S. Department of Energy, Richland Operations Office

G. M. Bell

A5-52

M. E. Burandt

K8-50

C. E. Clark

A5-15

R. N. Krekel

A5- 15

E. M. Mattlin

A5-15

A. C. McKarns

A5-15

H. M. Rodriguez

A5- 15

Public Reading Room

H2-53

Fluor Daniel Hanford, Inc.

C. G. Mattson

N1-21

L. J. Olguin

N1-26

S. M. Price

H6-23

F. A. Ruck III

H6-23

S. A. Thompson

H6-23

A. M. Umek

N. H. Williams

S7-40

B. D. Williamson

B\&W Hanford Company

K. A. Hadley

R3-56

Bechtel Hanford, Inc.

S. J. Ingle

H9-02

R. J. Landon

$\mathrm{H} 0-02$

P. J. Mackey

$\mathrm{H} 0-13$

Document and Information Services

H0-09

DynCorp Tri-Cities Services, Inc.

B. J. Dixon

G3-26

Lockheed Martin Hanford Corporation

B. G. Erlandson

R2-36 
Lockheed Martin Services, Inc.

Central Files

A3-88

Document Processing Center

A3-94

EDMC (2)

H6-08

Pacific Northwest National Laboratory

P. L. Hendrickson

K8-03

G. W. McNair

P7.79

H. T. Tilden II

P7-79

Waste Management Federal Services of Hanford, Inc.

R. C. Bowman

$\mathrm{H} 6-24$

R. E. Engelmann

H6-26

E. M. Greager

H6-36

J. C. Sonnichsen

H6-24

J. A. Winterhalder

H6-21

M. T. Yasdick

H6-10 
DOE/RL-96-63; Rev. 1

10/97

This page intentionally left blank.

Distr-4 